This report was prepared as an account of work sponsored by an agency of the United States Government. Neither the United States Government nor any agency thereof, nor any of their employees, makes any warranty, express or implied, or assumes any legal liability or responsibility for the accuracy, completeness, or usefulness of any information, apparatus, product, or process disclosed, or represents that its use would not infringe privately owned rights. Reference herein to any specific commercial product, process, or service by trade name, trademark, manufacturer, or otherwise does not necessarily constitute or imply its endorsement, recommendation, or favoring by the United States Government or any agency thereof. The views and opinions of authors expressed herein do not necessarily state or reflect those of the United States Government or any agency thereof.

\title{
A Process for Establishing a Financial Assurance Plan for LLW Disposal Facilities
}

Paul Smith

April 1993

Idaho National Engineering Laboratory

EG\&G Idaho, Inc.

National Low-Level Waste Management Program

Idaho Falls, ID 83415

\section{MASTER}

\author{
Prepared by Rogers \& Associates Engineering Corporation \\ for the U.S. Department of Energy \\ Office of Environmental Restoration and Waste Management \\ DOE Idaho Field Office
}

under DOE Contract No. DE-AC07-76ID01570 



\section{DISCLAIMER}

Portions of this document may be illegible in electronic image products. Images are produced from the best available original document. 


\begin{abstract}
This document describes a process by which an effective financial assurance program can be developed for new low-level radioactive waste (LLW) disposal facilities. The report identifies examples of activities that might cause financial losses and the types of losses they might create, discusses mechanisms that could be used to quantify and ensure against the various types of potential losses identified and describes a decision process to formulate a financial assurance program that takes into account the characteristics of both the potential losses and available mechanisms. A sample application of the concepts described in the report is provided.
\end{abstract}

\title{
PURPOSE OF REPORT
}

The purpose of this report is to describe a basic process for identifying and addressing financial assurance needs of low-level radioactive waste disposal facilities; the methods presented must be modificd to reflect the unique needs, conditions, and policies of each specific low-level radioactive waste disposal facility. The example in Appendix $\mathrm{A}$ is presented solely to illustrate how the ideas discussed in the report might be applied to a hypothetical facility. The classification and magnitude of the costs presented in the appendix should not be viewed as representative of potential liabilities at any actual lacility. 


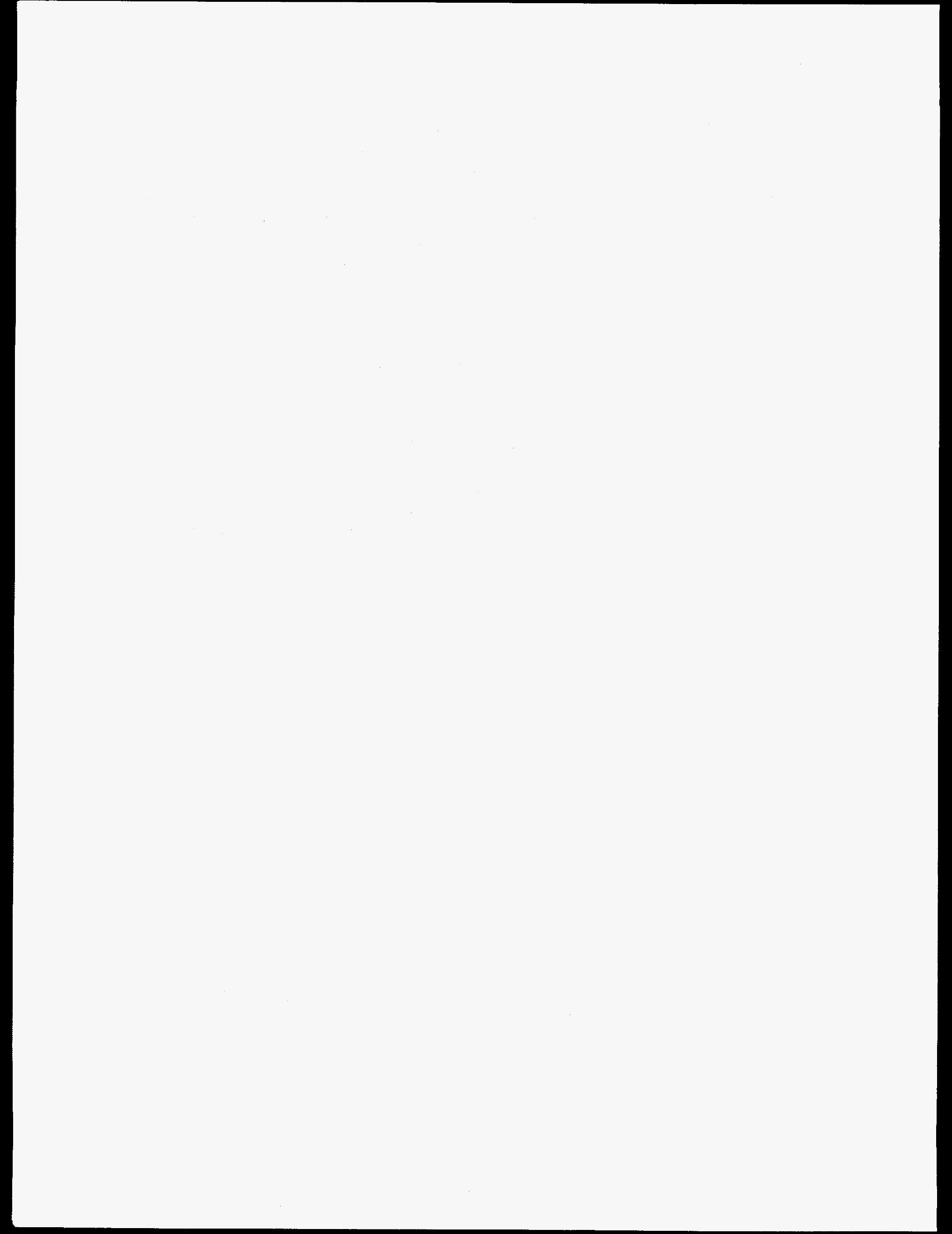




\section{EXECUTIVE SUMMARY}

Under provisions of the Low-Level Radioactive Waste Policy Amendments Act of 1985 (the Act), states must provide for the disposal of low-level radioactive waste (LLW) generated within their borders. The Act encouraged states to join together in compact regions for this purpose. The U.S. Department of Energy (DOE) is responsible for providing technical assistance to states and compact regions in the development of the new LLW disposal facilities. In connection with this responsibility, DOE has commissioned the work reported in this document.

Questions were raised concerning potential financial liabilities of LLW disposal facilities when three of the six commercially operated facilities were closed prematurely after problems with site stability and management of surface water. Although there were no claims made for damages, offsite contamination, or offsite remediation following the closure of the three facilities, it did lead to the recognition that more comprehensive standards, technical criteria, and licensing procedures were needed. These needs were addressed by the U.S. Nuclear Regulatory Commission in December 1982, when it promulgated a new part to Title 10 of the Code of Federal Regulations-Part 61, "Licensing Requirements for Land Disposal of Radioactive Wastes" (10 CFR 61). This regulation established a series of performance objectives and technical requirements that each new LLW disposal facility and facility operator must meet in order to ensure public health, safety, and long-term protection of the environment.

These regulations also provided some guidance on financial assurance, but only addressed one potential activity that should be included in a financial assurance plan: premature closure.

Unlike most other facilities, the potential for financial losses after a LLW disposal facility is closed becomes smaller as time passes. This is because most of the radioactivity contained in the waste is short-lived and constantly decreasing. Financial assurance programs should take into account the decreasing risk posed by a constantly shrinking amount of radioactivity in the waste.

The principal objective of this document is to describe a process by which an effective financial assurance program can be developed for LLW disposal facilities. To do this, the report has been structured in the following manner:

- $\quad$ Survey of activities that might cause financial losses (Chapter 2)

- Identification of potential financial losses (Chapter 2)

- Presentation of approaches for quantifying probabilities and magnitudes of losses (Chapter 3)

- Description of financial assurance mechanisms (Chapter 4)

- Description of a decision process for formulating a financial assurance program (Chapter 4) 
- Sample application of the concepts contained in this document in preparing a financial assurance program for a hypothetical LLW disposal facility (Appendix A).

The principal information presented in this document is summarized below.

\section{Survey of Potential Financial Losses}

The lack of claims at the six existing LLW disposal facilities makes it impossible to use historical data to determine the types of potential losses that damage claims might create, the most appropriate financial assurance mechanisms to use, or the levels of financial assurances that a financial assurance plan should provide for new LLW disposal facilities. Given this constraint, this report begins by identifying types of activities and potential damages that would be most helpful in describing how financial assurance programs might be developed. These activities are:

- Unusual operating conditions

- Extreme natural occurrences

- Premature disposal unit failure

- Trespass.

The owner/operators and users of the facility would be responsible for paying these losses if they were to occur. These activities and a summary of the potential financial losses they might lead to are listed in Table I.

\section{Evaluation of Potential Financial Losses}

In order to prepare a financial assurance program, the probabilities of activities must be estimated. Because little probability data is available from the current and closed disposal facilities, alternate data sources must be used. These would include:

- National Safety Council

- National Council of Compensation Insurers

- National Oceanographic and Atmospheric Administration

- Insurance companies

- Federal insurance programs

- Federal Aviation Administration

- Insurance Service Office 
Table I. Summary of assumed potential financial losses by activity.

\begin{tabular}{|c|c|c|c|c|}
\hline \multirow[b]{2}{*}{ Assumed Potential Financial Losses } & \multicolumn{4}{|c|}{ Assumed Activities } \\
\hline & 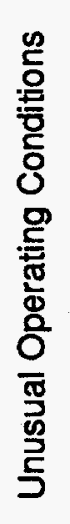 & 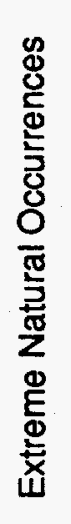 & 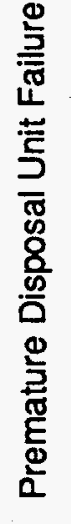 & 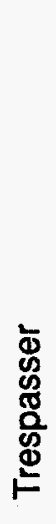 \\
\hline Bodily Injury by Workers & $\checkmark$ & $\checkmark$ & & \\
\hline Personal Injury by Workers & $\checkmark$ & $\checkmark$ & & \\
\hline Environmenta//Compliance Monitoring & $\checkmark$ & $\checkmark$ & $\checkmark$ & \\
\hline Decontamination of Onsite Property & $\checkmark$ & $\checkmark$ & $\checkmark$ & $\checkmark$ \\
\hline Repair/Replace Disposal Unit & & $\checkmark$ & $\checkmark$ & \\
\hline Relocation Waste & & $\checkmark$ & $\checkmark$ & \\
\hline Bodily Injury by the General Public & $\checkmark$ & $\checkmark$ & $\checkmark$ & $\checkmark$ \\
\hline Personal Injury by the General Public & $\checkmark$ & $\checkmark$ & $\checkmark$ & $\checkmark$ \\
\hline Property Damage by the General Public & $\checkmark$ & $\checkmark$ & $\checkmark$ & $\checkmark$ \\
\hline Economic Losses by the General Public & $\checkmark$ & $\checkmark$ & $\checkmark$ & \\
\hline Devalued Property by the General Public & $\checkmark$ & $\checkmark$ & $\checkmark$ & $\checkmark$ \\
\hline Medical Monitoring & $\checkmark$ & $\checkmark$ & $\checkmark$ & $\checkmark$ \\
\hline Legal Defense Costs & $\checkmark$ & $\checkmark$ & $\checkmark$ & $\checkmark$ \\
\hline Environmental Restoration & & $\boldsymbol{\sim}$ & $\boldsymbol{V}$ & \\
\hline
\end{tabular}


- Design engineers and scientists involved with LLW disposal facility design and performance analysis.

The evaluation of each potential financial loss requires information about when the activity might occur, potential impacts, responses of workers and members of the general public, probabilities of success in collecting damages, and the associated monetary costs. Many of the data sources listed above are useful in estimating values for these parameters.

\section{Structuring a Financial Assurance Program}

Workers' Compensation insurance and the associated employer liability coverage are readily available to provide some protection against injury claims by facility workers. Any claims in excess of available coverage must be self-insured. Since no insurance is presently available for onsite losses, protection must be provided by self-insurance. Sudden and accidental offsite losses can presently be covered by insurance up to $\$ 25$ million. Any projected offsite losses in excess of available coverage must also be self-insured.

Self-insurance may be funded prior to or after a loss is experienced. Self-insurance may be accomplished individually (each facility independently of others) or through a pooling arrangement between several or all disposal facilities.

The key decisions necessary to formulate a financial assurance program is described by the flow chart presented in Figure I. This figure demonstrates that:

- $\quad$ Risks should be avoided or minimized by reducing their probabilities and potential magnitudes

- Some risks may be transferred by contract or through insurance

- Risks not avoided or transferred must be self-insured

- Self-insurance may be prefunded, postfunded, or in combination

- Self-insurance may be accomplished individually or through pooling with other disposal facilities.

\section{Example Application}

The concepts presented in this document are used to evaluate a hypothetical LLW disposal facility in Appendix A. The sole purpose of Appendix $A$ is to provide an example of how the approaches described in Chapters 2, 3, and 4 of this document might be applied. The values presented in this appendix cannot be validly applied to any actual or potential LLW disposal facility; such application could be misleading. 


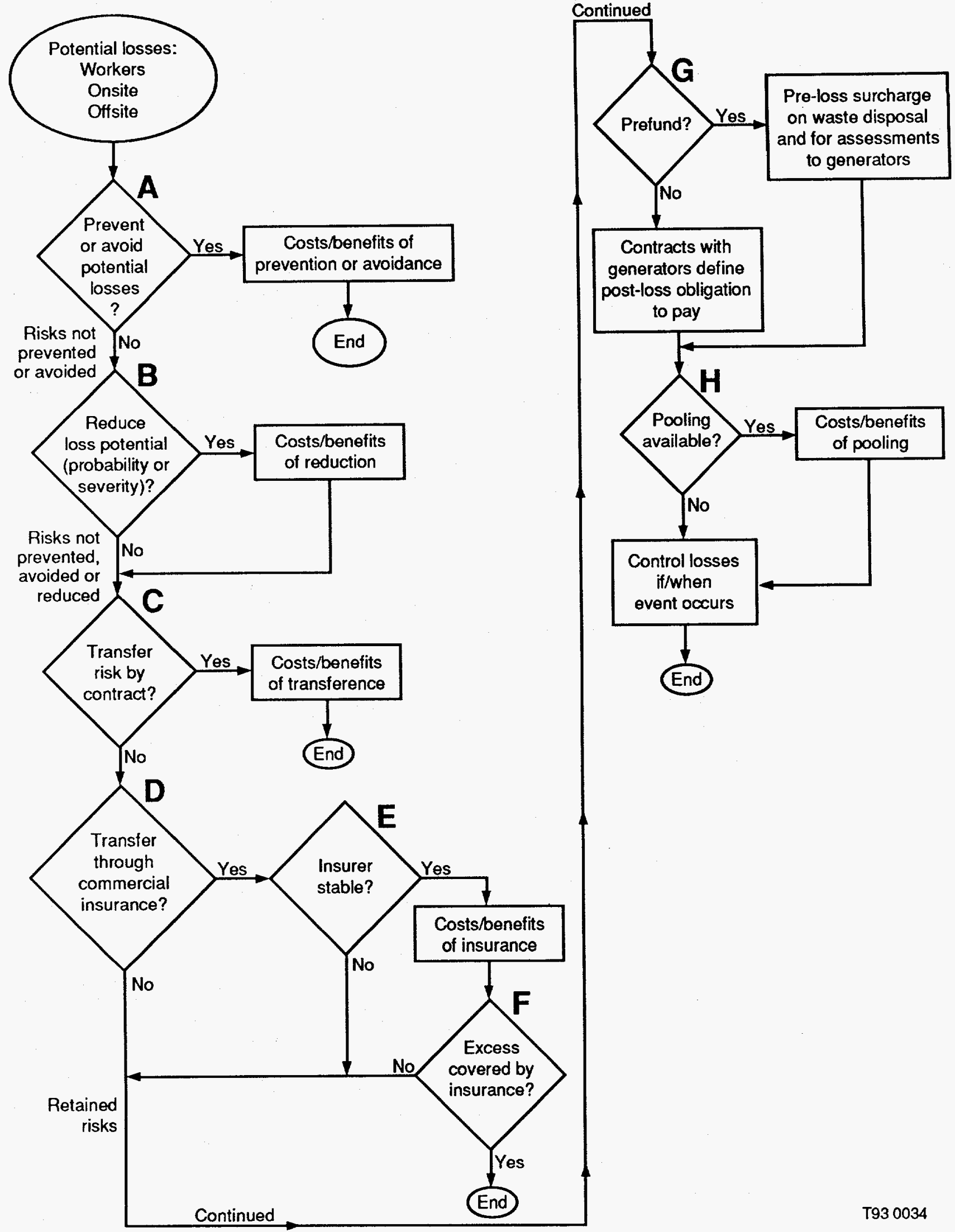

Figure I. Flow chart of key decisions to formulate a financial assurance program. 



\section{CONTENTS}

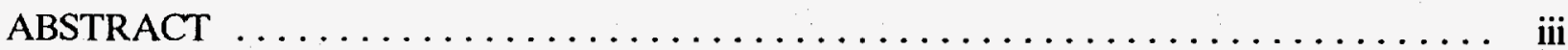

PURPOSE OF REPORT $\ldots \ldots \ldots \ldots \ldots \ldots \ldots \ldots \ldots \ldots \ldots \ldots \ldots \ldots \ldots \ldots$

EXECUTIVE SUMMARY $\ldots \ldots \ldots \ldots \ldots \ldots \ldots \ldots \ldots \ldots \ldots \ldots \ldots \ldots$

1. INTRODUCTION $\ldots \ldots \ldots \ldots \ldots \ldots \ldots \ldots \ldots \ldots \ldots \ldots \ldots \ldots \ldots \ldots \ldots \ldots$

2. SURVEY OF POTENTIAL FINANCIAL LOSSES $\ldots \ldots \ldots \ldots \ldots \ldots$

2.1 Summary of Potential Financial Losses $\ldots \ldots \ldots \ldots \ldots \ldots \ldots \ldots \ldots \ldots$

2.2 Potential Loss-Producing Activities $\ldots \ldots \ldots \ldots \ldots \ldots \ldots \ldots \ldots \ldots$

2.2.1 Unusual Operating Conditions $\ldots \ldots \ldots \ldots \ldots \ldots \ldots \ldots \ldots \ldots \ldots$

2.2 .2 Extreme Natural Occurrences $\ldots \ldots \ldots \ldots \ldots \ldots \ldots \ldots \ldots \ldots \ldots$

2.2.3 Premature Disposal Unit Failure $\ldots \ldots \ldots \ldots \ldots \ldots \ldots \ldots \ldots \ldots \ldots \ldots$

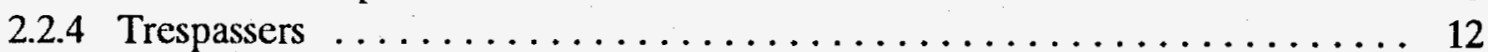

2.2.5 Other Activities Considered $\ldots \ldots \ldots \ldots \ldots \ldots \ldots \ldots \ldots \ldots \ldots \ldots \ldots$

2.3 Potential Financial Losses from Listed Activities $\ldots \ldots \ldots \ldots \ldots \ldots \ldots$

2.3.1 Claims from Facility Workers $\ldots \ldots \ldots \ldots \ldots \ldots \ldots \ldots \ldots \ldots \ldots \ldots$

2.3 .2 Onsite Claims . . . . . . . . . . . . . . . . . . . . . 15

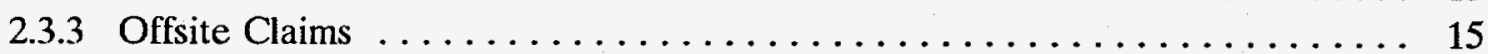

3. EVALUATION OF POTENTIAL FINANCIAL LOSSES $\ldots \ldots \ldots \ldots \ldots \ldots \ldots$

3.1 Overview of Evaluation Process $\ldots \ldots \ldots \ldots \ldots \ldots \ldots \ldots \ldots \ldots \ldots \ldots \ldots \ldots$

3.2 Evaluating Probabilities of Activities $\ldots \ldots \ldots \ldots \ldots \ldots \ldots \ldots \ldots \ldots \ldots$

3.2 .1 Unusual Operating Conditions $\ldots \ldots \ldots \ldots \ldots \ldots \ldots \ldots \ldots \ldots \ldots \ldots$

3.2 .2 Extreme Natural Occurrences $\ldots \ldots \ldots \ldots \ldots \ldots \ldots \ldots \ldots \ldots \ldots \ldots$

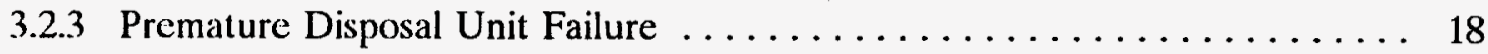

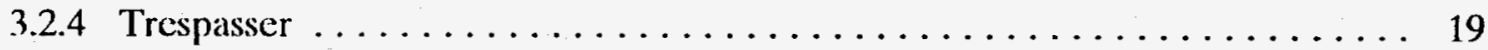

3.3 Claims by Workers $\ldots \ldots \ldots \ldots \ldots \ldots \ldots \ldots \ldots \ldots \ldots \ldots \ldots \ldots$

3.3.1 Bodily Injury to Workers from Industrial Hazards $\ldots \ldots \ldots \ldots \ldots \ldots \ldots$

3.3.2 Bodily Injury to Workers from Radiological Hazards . . . . . . . . . . . 20

3.3.3 Personal Injury to Workers from Radiological Hazards . . . . . . . . . . 21

3.3.4 Legal Costs Resulting from Workers' Claims . . . . . . . . . . . 22 


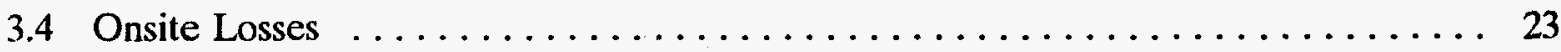

3.4.1 Additional Environmental and Compliance Monitoring $\ldots \ldots \ldots \ldots \ldots$

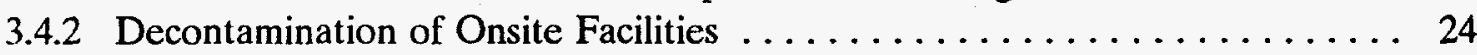

3.4.3 Remedial Action for Failed Disposal Units $\ldots \ldots \ldots \ldots \ldots \ldots \ldots \ldots$

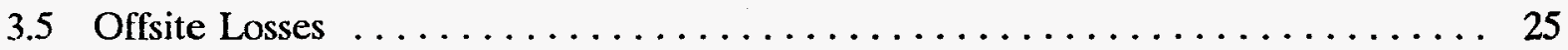

3.5.1 Claims of Bodily Injury to Members of the General Public . . . . . . . . 25

3.5.2 Claims of Personal Injury to Members of the General Public . . . . . . . . 26

3.5 .3 Claims of Property Damage . . . . . . . . . . . . . . . . 27

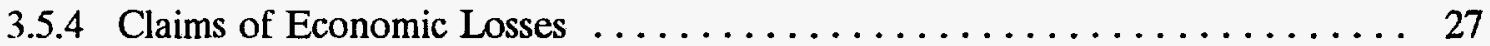

3.5.5 Costs of Medical Monitoring for the General Public ... . . . . . . . 29

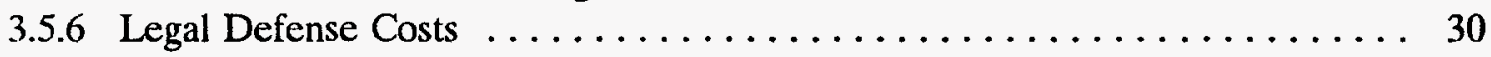

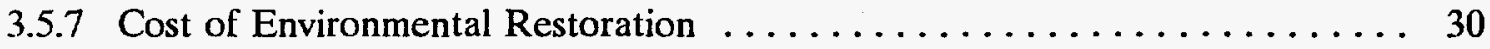

3.6 Determining the Present Value of Potential Losses $\ldots \ldots \ldots \ldots \ldots \ldots$

4. STRUCTURING A FINANCIAL ASSURANCE PROGRAM $\ldots \ldots \ldots \ldots \ldots \ldots$

4.1 Summary of Financial Assurances $\ldots \ldots \ldots \ldots \ldots \ldots \ldots \ldots \ldots \ldots \ldots \ldots \ldots$

4.2 Currently Available Insurance for Onsite and Offsite Losses $\ldots \ldots \ldots \ldots$

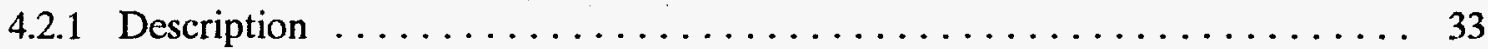

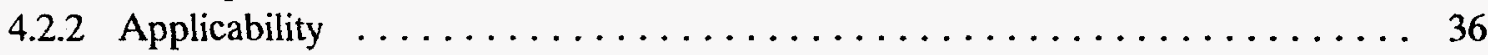

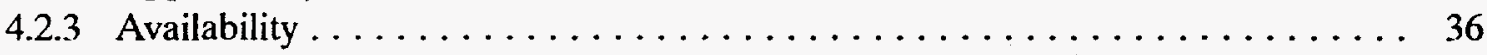

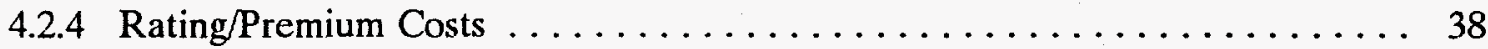

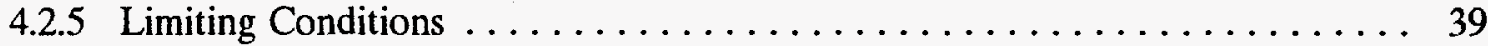

4.3 Self-Insurance (Each Facility Alone) $\ldots \ldots \ldots \ldots \ldots \ldots \ldots \ldots \ldots \ldots$

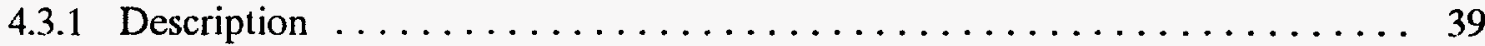

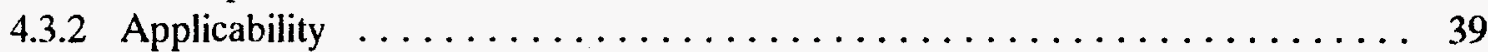

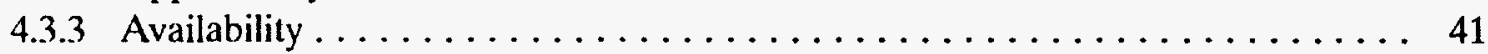

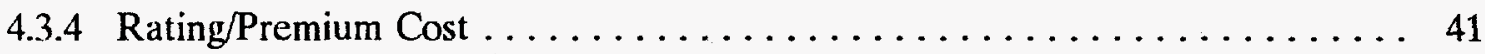

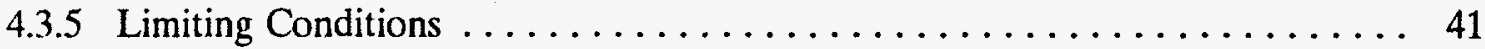

4.4 Self-Insurance (Insurance Pool) $\ldots \ldots \ldots \ldots \ldots \ldots \ldots \ldots \ldots \ldots \ldots \ldots \ldots \ldots$

4.4.1 Description $\ldots \ldots \ldots \ldots \ldots \ldots \ldots \ldots \ldots \ldots \ldots \ldots \ldots \ldots \ldots \ldots \ldots \ldots \ldots \ldots \ldots$

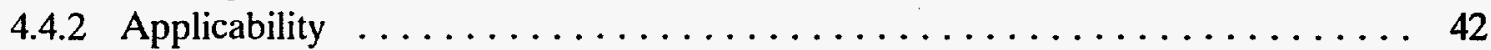

4.4 .3 Availability and Limiting Conditions $\ldots \ldots \ldots \ldots \ldots \ldots \ldots \ldots \ldots \ldots \ldots$

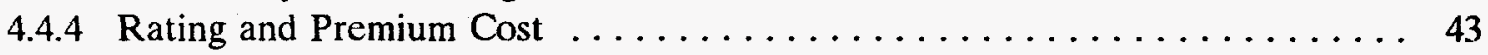

4.5 Other Financial Assurance Mechanisms $\ldots \ldots \ldots \ldots \ldots \ldots \ldots \ldots \ldots$ 
4.6 Formulating a Financial Assurance Program . . . . . . . . . . . . . 44

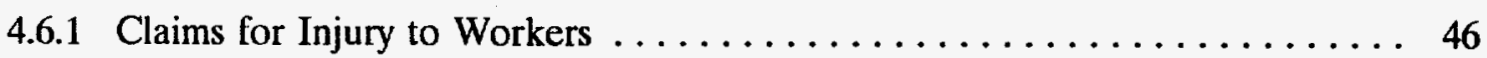

4.6 .2 Onsite Losses . . . . . . . . . . . . . . . . . . . . 47

4.6.3 Claims for Injury or Property Damage by Offsite Parties $\ldots \ldots \ldots \ldots \ldots . .48$

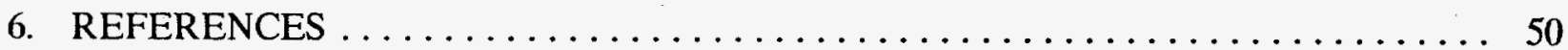

Appendix A-Sample Application of Approaches to Developing a

Financial Assurance Program

Appendix B-Reference Disposal Facility Description

B-1

Appendix C-Vault Failure Analysis

Appendix D-Glossary

D-1

Appendix E-Bibliography E-1 


\section{A Process for Establishing a Financial Assurance Plan for LLW Disposal Facilities}

\section{INTRODUCTION}

Under authority of the Atomic Energy Act of $1954,{ }^{1}$ as amended, the disposal of low-level radioactive waste (LLW) is regulated by the U.S. Nuclear Regulatory Commission (NRC). The NRC has established an Agreement State program that allows qualified states to be responsible for LLW disposal activities within their borders.

To date, six commercially operated LLW disposal facilities have been licensed by either the NRC or the Agreement State in which they are located. Three disposal facilities are currently receiving LLW: Barnwell, South Carolina; Richland, Washington; and Beatty, Nevada. Three other facilities have been closed for over 10 years: West Valley, New York; Maxey Flats, Kentucky; and Sheffield, Illinois. The three closed facilities discontinued receiving waste after they experienced problems with site stability and management of surface water. Environmental monitoring determined that the disposal trenches at West Valley, Maxey Flats, and Sheffield collected water that remained in the trenches until it overflowed or found another way out. The water accumulated because several trenches experienced slumping, which allowed precipitation to enter the trenches.

It should be noted that no offsite remediation was necessary at any of the three closed facilities. The monitoring systems at the facilities detected the leakage and afforded facility operators and regulators the time needed to take appropriate mitigation activities.

These problems, experienced in the developmental years of commercial LLW disposal, led to the recognition that more comprehensive standards, technical criteria, and licensing procedures were needed. These needs were addressed by the NRC in December 1982, when it promulgated a new addition to Title 10 of the Code of Federal Regulations known as Part 61, "Licensing Requirements for Land Disposal of Radioactive Waste" (10 CFR 61). ${ }^{2}$ This regulation established a series of performance objectives and technical and financial requirements that new LLW disposal facilities and facility operators must meet to ensure public health, safety, and long-term protection of the environment.

According to the requirements of 10 CFR 61, Subpart E, an applicant submitting a license to develop and operate a LLW disposal facility must ensure that adequate financial provisions exist for the routine development, operation, closure, long-term maintenance, and premature closure of the facility. Provisions of 10 CFR 61 specify several financial assurances and describe acceptable financial assurance mechanisms. However, $10 \mathrm{CFR} 61$ does not provide guidance for determining what assurances might be required to protect against other forms of potential loss, such as offsite damages and remedial action costs.

In 1980, the Low-Level Radioactive Waste Policy $\mathrm{Act}^{3}$ became law; it was amended by the Low-Level Radioactive Waste Policy Amendments Act of 1985 (the Act). ${ }^{4}$ The major effect of these statutes was to make individual states responsible for disposal of LLW generated within their borders. These laws also authorized and encouraged the formation of interstate compact regions of states for 
the purpose of LLW disposal. In response to the requirements and encouragement of these laws, several states have begun the process of developing new LLW disposal facilities.

As the process of developing new disposal facilities progressed, concern was expressed about the potential losses that might be borne by facility owner/operators and users due to damage claims filed by residents near the facility or by workers. Because the currently operating and closed disposal facilities do not have data that adequately addresses these concerns, additional information is needed to properly address these potential losses.

Because of the nature of financial assurances, it is vital that effective, accurate assessments and evaluations be conducted during the planning stages for LLW disposal facilities rather than some later time. Establishing proper financial assurances is essential not only for proper cost accounting at disposal facilities, but also for satisfying regulators and the public at large.

To date, relatively few financial assurance guidelines have been developed for states and developers of LLW disposal facilities. The State of New York recently published a final generic environmental impact statement for promulgation of its financial assurance regulations. ${ }^{5}$ The statement identifies and evaluates activities and conditions that might produce financial losses and considers a range of regulatory options. The U.S. Environmental Protection Agency (EPA) has also issued a background document on financial responsibility requirements for closure and postclosure of hazardous waste treatment, storage, and disposal facilities. ${ }^{6}$ The Northeast compact region sponsored a workshop on financial assurance requirements in July 1989. This workshop resulted in several papers that examined liability issues and alternatives to traditional insurance for new LLW disposal facilities. ${ }^{7}$ The State of Washington has prepared and submitted to its legislature a review of financial responsibility for liability and cleanup of radioactive materials at licensed facilities. ${ }^{8}$

Since the Act assigns the U.S. Department of Energy (DOE) the responsibility of providing technical assistance to states and compact regions developing LLW disposal facilities, DOE has undertaken this report on financial assurances. The main objective of this report is to describe the process by which an effective financial assurance program can be developed.

Although no attempt has been made to detail the many variations in state liability rules, this report assumes that state and federal law will make licensed low-level radioactive waste disposal facility owner/operators and users primarily liable for any injury to persons, property, or the environment that result from facility operations. Furthermore, this report assumes that facilities will be held liable for any losses that occur even if the facility operator exercises the utmost care. If exposure to radiation or radioactive materials were to occur, this report conservatively assumes that damages would likely be awarded in the absence of proof of present injury. Consequently, we have assumed that the financial assurance package would provide for any contingent costs that would not exist but for the existence of the facility.

The overall objective of this report is accomplished through the following activities:

- Summarize and characterize the ways in which abnormal activities might create financial losses during the operation, closure, and maintenance of a LLW disposal facility 
- Provide a way for estimating the potential financial losses and cvaluating their associated probabilities of occurrence

- Identify financial assurance mechanisms available to protect against these risks and describe how a financial assurance program might be structured.

In completing these activities, no attention is given to the financial arrangements that should be provided to ensure facility closure, long-term maintenance, or premature closure; these issues are addressed by the NRC.

This report includes the following information:

- A summary of activities and the resulting ways in which financial losses might occur (Chapter 2)

- Descriptions of approaches that can be used to quantify the probabilities of various activities and the magnitudes of the potential losses that might result (Chapter 3 )

- A summary of how currently available financial assurance mechanisms might be used to structure a comprehensive program for new LLW disposal facilities (Chapter 4)

- A sample application ${ }^{9}$ of how the principles discussed in this report can be used to evaluate potential liabilities and establish an effective financial assurance program (Appendices A through $\mathrm{C}$ ).

The logical relationship of each subject of the main body of the report to the others is depicted in Figure 1. Information generated by activities on the left is provided as input to subsequent activities (farther to the right) in order to accomplish all activities. Clearly, accomplishing these activities require many inputs that depend on the characteristics of:

- The natural site at which the facility is developed

- The facility design

- Operating procedures

- Waste accepted for disposal.

Rather than determine typical levels for various types of financial assurance needs, this document presents a sequence of activities that individual states and compact regions would undertake to identily and characterize their financial assurance needs. Although elementary in appearance, these activities will likely require the services of several technical professionals experienced in matters relating to LLW disposal, including:

- Attorneys

- Actuaries 
Determine Objectives of Financial Assurance

$$
\text { Program }
$$

$A$

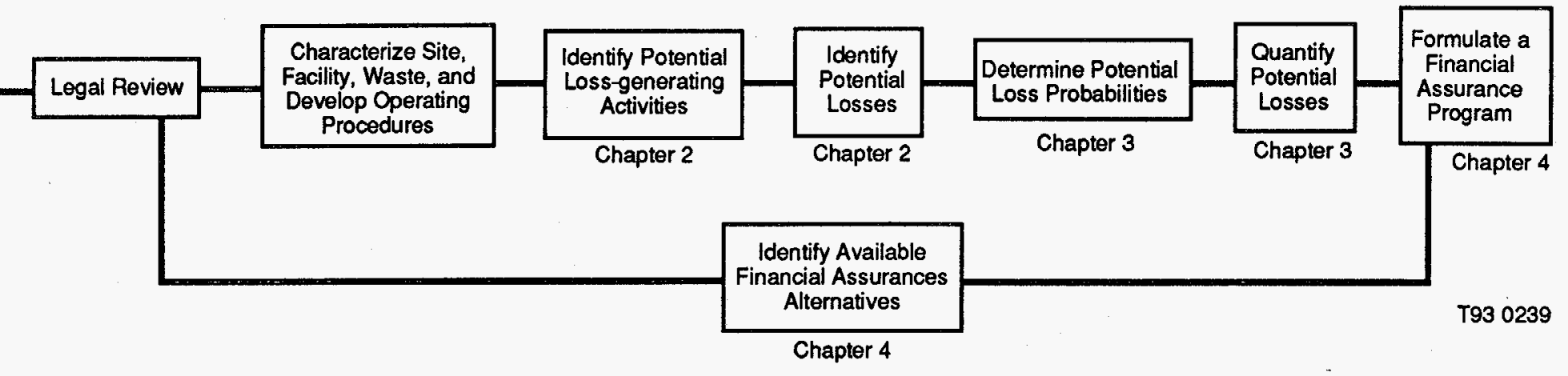

Figure 1. Steps in developing a financial assurance program. 
- Design/operations engineers

- Health physicists

- Environmental risk assessors

- Financial risk managers.

The information presented in this document can be useful in helping state and compact personnel:

- Understand the process of establishing a financial assurance program

- Prepare scopes of work for solicitation documents

- Evaluate proposals

- Oversee and evaluate the conduct of the work contractors.

A final note of caution regarding the use of Appendices A, B, and C: Because of the hypothetical nature of the facility (Reference 9) and site used as a basis for this investigation, values used in the example presented in Appendices $A$ through $C$ cannot be used in making decisions for any existing or planned disposal facility; however, the process used is valid for any disposal facility. Estimates of radiological and financial impacts, their timing, and probabilities are unique to each facility. Even if the hypothetical facility were an actual facility, generalizing the quantitative conclusions for application to other actual facilities would be invalid because of significant site-and facility-specific dependencies. 


\section{SURVEY OF POTENTIAL FINANCIAL LOSSES}

In order to satisfy the potential financial demands created by unusual activities, and claims by workers and the general public, LLW disposal facilities should establish appropriate financial assurances. However, the level of financial assurance must be determined before an appropriate financial assurance program or plan can be structured. The approach to determining this information is the topic of this and the following chapter. In this chapter the ways in which financial losses might occur are identified and characterized. In the following chapter, possible approaches to estimating adequate levels of financial assurance are presented.

\subsection{Summary of Potential Financial Losses}

It is assumed, for purposes of this report, that financial losses might occur as the result of several types of activities. These activities might include:

- Unusual operating conditions

- Extreme natural occurrences

- Premature disposal unit failure

- Trespass.

Other activities could be postulated, based on the particular circumstances of individual LLW disposal facilities and their physical and regulatory settings. Those offered above, while not a complete listing, are considered adequate for the purposes of this document to bound the activities that might produce potential financial losses. Other potential actions identified, but not evaluated in this document, include routine operations, social or labor unrest, large-scale land development, premature closure, and the routine closure and long-term maintenance of the facility.

If an activity listed above were to occur, damage might be sustained by facility workers, members of the general public, or onsite facilities. With this in mind, potential financial losses might be caused by:

- Injuries resulting from exposure to radioactive material

- Injuries wrongly perceived to have resulted from exposure to radioactive material

- Mitigating and preventing further injury or property damage (including remediation and public health screening and monitoring) to workers and nearby residents

- Defending suits alleging injury

- Compensation for reduced property values. 
Because these potential losses might occur at various times in the facility's life, their values in terms of today's dollars would depend on when or if they actually occur.

The first and second categories both refer to adverse judgments for claims alleging injuries due to exposure to radiation that are made by workers or members of the general public. While it is possible to distinguish between these categories in theory, it is difficult to distinguish between them in practice. For example, even if the disposal facility were not there, it is likely that some people in the area would develop health problems. It would be difficult, if not impossible, to distinguish between those people and others whose health problems may indeed be related to radiation exposure. While claims in the first category can be minimized through changes in the design and operation of the facility, there is little that can be done to minimize claims in the second category.

The last three categories involve the costs of dealing with an adverse activity in both the field and the courtroom. These costs might result from claims made by workers, members of the general public, or regulators.

\subsection{Potential Loss-Producing Activities}

Because potentially large linancial impacts might be incurred if the facility does not perform properly, the owner/operator has great incentive to ensure proper operation. To reduce this risk, asscssments are made throughout the life of the facility to identify potential weaknesses in the facility design, operating procedures, and plans for closure and postclosure care. If a weakness were found, modifications would be implemented to minimize the potential for damages. This continuing process of assessing the safety of a facility is a common and expected practice throughout the design and construction industries and creates an ever-decreasing potential that losses might occur.

Conservative performance assumptions are used that will generate an upper bound for the potential costs that a financial assurance program must address. For example, this document gives no credit for the routine correction of potential weaknesses discovered and corrected as described above. This document also assumes that even if the facility experiences no accidents or abnormal activities and meets all applicable regulatory standards, workers will claim that any cancers they suffer are due to their employment at the LLW facility.

\subsubsection{Unusual Operating Conditions}

It is assumed, for the purposes of this report only, that the following unusual conditions might oecur and subject facility workers, members of the general public, and the environment to unusual hazards. ${ }^{10}$

- Defective waste containers might arrive at the disposal facility

- A fire might occur during the process of repackaging a defective waste container

- A waste container might rupture during handling operations

- A concrete cover block used for shielding disposal units might be dropped onto disposed waste containers, causing several to rupture 
- A crane handling a waste container might malfunction with the container suspended such that the container must be transferred to another crane.

Although other activities could be projected, the preceding activities are judged to potentially produce the most severe impacts. Intentional acts that produce hazards to facility workers and the general public are described in Section 2.2.5.

The effects of these accidents and unusual conditions are assumed to include:

- Release of radioactive materials to building surfaces, soil surfaces, air, and water

- Transport of contamination from the facility to adjacent waterways, land areas, and buildings

- Unusual radiation exposures to facility workers or the general public because of inhaled or ingested radioactive materials or radiation from waste containers.

If any of these potential accidents were to occur, the following mitigative and remedial actions are representative of those that would be taken immediately to minimize the impacts to the facility and the surrounding area:

- Workers would wear protective devices

- Alarms would sound

- Emergency response support would be summoned

- Effects of the accident or unusual condition would be contained to the extent possible without unreasonably endangering facility workers

- Onsite and offsite cleanup efforts would be initiated as necessary and completed to remove the hazards and satisfy regulatory requirements.

The potential financial losses assumed is this report that might result from unusual operating conditions and other activities are listed in Table 1.

\subsubsection{Extreme Natural Occurrences}

The design of the LLW disposal facility assumes that several potentially disruptive natural events might occur. Such events include:

- $\quad$ Probable maximum precipitation event

- $\quad$ Probable maximum flood 
Table 1. Summary of assumed potential financial losses by activity.

\begin{tabular}{|c|c|c|c|c|}
\hline \multirow[b]{2}{*}{ Assumed Potential Financial Losses } & \multicolumn{4}{|c|}{ Assumed Activities } \\
\hline & 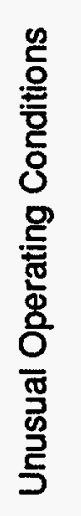 & 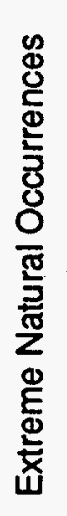 & 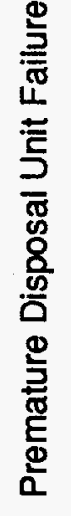 & 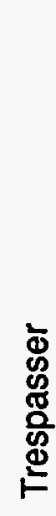 \\
\hline Bodily Injury by Workers & $\checkmark$ & $\checkmark$ & & \\
\hline Personal Injury by Workers & $\checkmark$ & $\checkmark$ & & \\
\hline Environmental/Compliance Monitoring & $\checkmark$ & $\checkmark$ & $\checkmark$ & \\
\hline Decontamination of Onsite Property & $\checkmark$ & $\checkmark$ & $\checkmark$ & $\checkmark$ \\
\hline Repair/Replace Disposal Unit & & $\checkmark$ & $\checkmark$ & \\
\hline Relocation Waste & & $\sim$ & $\checkmark$ & \\
\hline Bodily Injury by the General Public & $\checkmark$ & $\checkmark$ & $\checkmark$ & $\checkmark$ \\
\hline Personal Injury by the General Public & $\checkmark$ & $\checkmark$ & $\checkmark$ & $\checkmark$ \\
\hline Property Damage by the General Public & $\checkmark$ & $\checkmark$ & $\checkmark$ & $\checkmark$ \\
\hline Economic Losses by the General Public & $\checkmark$ & $\checkmark$ & $\checkmark$ & \\
\hline Devalued Property by the General Public & $\checkmark$ & $\checkmark$ & $\checkmark$ & $\checkmark$ \\
\hline Medical Monitoring & $\checkmark$ & $\checkmark$ & $\checkmark$ & $\checkmark$ \\
\hline Legal Defense Costs & $\boldsymbol{r}$ & $\checkmark$ & $\checkmark$ & $\checkmark$ \\
\hline Environmental Restoration & & $\checkmark$ & $\checkmark$ & \\
\hline
\end{tabular}

T93 0033 
- Design basis earthquake

- Tornados.

These natural events are factored into the engineering design basis, which is the predetermined set of critcria and conditions for which the disposal facility must be designed. By designing the disposal facility to withstand the effects of these conditions, reasonable assurance exists that the disposal facility will perform as intended and required under most conceivable conditions.

For the purpose of this report, however, it is assumed that these design conditions might be exceeded by an extreme natural occurrence. For example, a more intense rainfall event or an earthquake might occur with greater forces than were planned for in designing the facility. If such an extreme event were to occur, radioactive material might be released from the disposal facility. The potential losses from such a release would depend on the following:

- Facility design

- Severity of the extreme natural occurrence

- $\quad$ Timing of the occurrence in the facility lifetime.

The first two items require analyses based on individual facility characteristics and conditions incident to the extreme natural occurrence. The timing of the occurrence is discussed below.

During the operational period, an extreme tornado, rainfall, or flooding might produce releases from the disposal facility by transporting waste containers from the disposal unit to adjacent areas. It is possible, although unlikely, that waste containers so removed might release their contents to the environment, causing radioactive contamination.

Potential financial losses from an extreme earthquake during the operating period of the facility would likely be less than if it occurred later in the facility's lifetime. Although there would be less radioactivity in the postclosure period, the very systems designed to ensure the integrity and long-term care of the facility would make it much more difficult and expensive to identify and repair the damage from an extreme earthquake.

Any radioactive release from a damaged container would be pursued just as it would under the accident conditions described in Section 2.2.1. Any structural damage that might occur to the active disposal units would be repaired, or new disposal units would be constructed and disposed waste would be relocated from the damaged unit. Additionally, the performance of disposal units that have been previously closed would be carefully monitored to ensure that no radioactive releases resulted. To the extent that unacceptable damage or performance were observed, appropriate remedial action would be taken to preclude unacceptable releases from the facility.

It is reasonable to expect that no releases would occur from disposal units following facility closure as a result of extreme natural events because of the several feet of earthen cover materials that are placed over the disposal units when the disposal facility is closed. Furthermore, releases resulting from an extreme earthquake would occur relatively slowly, since a transport medium (such 
as water) is required for the release to occur. This slow movement of radioactive materials would allow time for additional decay and increased monitoring or remedial action, if necessary.

A summary of the assumed potential financial losses that might result from extreme natural occurrences and other activities is listed in Table 1.

\subsubsection{Premature Disposal Unit Failure}

The requirements of 10 CFR 61 specify that locations for LLW disposal facilities be selected based on natural site characteristics that would keep radioactivity from reaching the facility boundaries and posing a health and safety hazard to the public even if the disposal units were to fail prematurely. In line with other conservative assumptions made in this report, the natural site characteristics are not taken into account in this discussion of premature failure of a disposal vault.

Because most new LLW disposal facilities use concrete structures in the disposal units, the long-term durability of concrete is of particular interest. Concrete, made of Portland cement and other ingredients, has been used in modern structures for nearly 200 years, and a significant body of information exists to ensure that the concrete is properly formulated and that concrete structures are properly designed, constructed, and maintained. Based on this information, disposal units are designed, constructed, and maintained using "worst case" assumptions about the structural and environmental conditions under which the structure will be required to perform. The result is a facility with a projected design life well in excess of that required by the state or operator. Thus, the design organization might provide a design with a projected life of 1,000 years to ensure that a 500 -year design life specified by the owner or regulator will be met when the "worst case" assumptions are applied.

As disposal structures gradually lose their ability to perform, undesirable observations would appear well before a radioactive release occurs. For example, monitoring systems would likely detect abnormally high moisture levels in a disposal unit, indicating structural degradation. Such a finding would alert operators to a potential radioactive release. However, because most of the radioactivity in waste is short-lived and constantly decreasing, the likelihood of any disposal vault failure posing a health or safety hazard to the public becomes smaller as time passes. Measures taken to mitigate premature disposal unit failure and minimize its effects might include the following:

- Increased structural and environmental monitoring

- Immediate attention to repairs and maintenance

- Stabilization of degraded disposal units

- Installation and operation of systems to intercept, collect, and treat contaminated groundwater

- Construction of a groundwater diversion system

- Restoration of contaminated natural resources 
- Removal and relocation of waste in failed disposal units to newly constructed disposal units.

Because it is prudent to assume "worst conditions" to formulate an adequate financial assurance program, it is assumed (for the purposes of this report only) that no observations are made to warn of impending disposal unit failure and that radioactive releases to groundwater systems occur. A summary of the assumed potential financial losses that might occur as a result of premature disposal unit failure and other events is listed in Table 1.

\subsubsection{Trespassers}

Although all LLW disposal facilities will be developed with security systems, unauthorized intentional entry is assumed in this document. Two types of trespassers have been postulated that might receive radiation exposures: (a) Trespasser/Sleeper, and (b) Trespasser/ Scavenger.

Although postulated, these events are not considered realistic for actual LLW disposal facilities. They are, however, described in the following paragraphs.

Trespasser/S/eeper. It is assumed that a trespasser evades existing security measures during the opcrating life of the facility and seeks shelter in a disposal vault. He sleeps in the vault in relatively close proximity to filled waste containers and departs the disposal facility, undetected, before operations commence for the day.

The Trespasser/Sleeper is assumed to be exposed because of the time spent in the radiation field of the disposed waste. However, this trespasser is assumed not to open any waste container, so that his person is not contaminated with, nor does he inhale or ingest, any radioactive material.

Because the trespasser has intentionally evaded existing security measures in order to take refuge in the disposal facility, any legal basis for a claim of damage is questionable. Nevertheless, it is assumed that such a claim is made and that the plaintiff prevails in the action. Clearly, the possibility of such a development could be essentially eliminated with greater emphasis on a more capable security system than has been assumed in this document.

Trespasser/Scavenger. The second trespasser case assumes that a juvenile evades existing security measures and intentionally opens disposed containers of Class A waste. In the process, this person is assumed to become contaminated with radioactive materials. Further, when he departs, he contaminates his home, as well as the path he uses. The Trespasser/Scavenger is assumed to open only Class A waste containers because it is only Class A waste may be disposed of without being solidified with a material such as concrete or put in a container that would ensure extended physical stability.

After a nominal period of time, the resulting contamination is assumed to be discovered either because contamination is discovered at or near the disposal facility or because the juvenile's parents, friends, or teachers grow suspicious that he may have trespassed onto the facility. In response to detected contamination or suspicion, investigations reveal the trespass. 
A summary of the assumed potential financial losses that might occur as a result of trespassers and other activities is listed in Table 1.

\subsubsection{Other Activities Considered}

In addition to the activities described above, it is possible to postulate several additional activities. Four of these additional activities are described in the following paragraphs.

Routine Operations. Even if the facility experiences no accidents or abnormal activities and meets all applicable regulatory standards, workers and the public might claim that any cancers they suffer are due to the presence of the LLW facility. Operations at LLW disposal facilities are carefully planned, conducted, and regulated to minimize radiation exposures to facility workers and to prevent exposures to the public above what would have been experienced without the facility. A wide variety of measures are used onsite to ensure that radiation exposures are within federally prescribed limits. These measures include:

- $\quad$ Limiting the number of workers involved in activities where radiation exposure is present

- $\quad$ Providing radiation shielding

- Restricting the time allowed for activities that produce radiation exposures

- Increasing the distance between the source of radiation and the workers exposed to the radiation

- Requiring the use of respiration devices if there is a potential for airborne radioactive material

- Prohibiting the ingestion of food or drink in areas where radioactive materials are potentially present

- Carefully and consistently monitoring and documenting the radiation exposures received by facility workers

- Monitoring the facility and personnel for exposures and contamination

- Monitoring the environment (e.g., air, water, soil, flora, and fauna) in the vicinity of the disposal facility for potential releases from the facility.

The net effect of these and other measures is to ensure that the radiation exposures to facility workers, the general public, and the environment will be as low as reasonably achievable and well within federal and state limits. Because these limits are set very low and only a remote probability exists of adverse health impacts from exposures during routine operations, this potential loss is not given further consideration in this report. 
Large-Scale Land Development. According to 10 CFR 61, the disposal facility will remain under the control of the state or Federal Government at all times following its closure. Nevertheless, the NRC allows the state or owner to take credit for only 100 years of such institutional control of the facility following closure in the performance assessment aspects of licensing the facility to ensure that it will continue to isolate the waste as intended without reliance on active measures.

Consistent with the practice described above, it could be assumed that institutional control of the disposal facility is lost several decades after closure. Furthermore, it could be assumed that institutional and public knowledge of the hazards at the disposal facility are also lost. Under these conditions, it might be postulated that the land area of the closed disposal facility would be viewed as a resource for commercial development. If such development were to occur, it might take the form of an occasional individual residence, a housing development, or a large commercial development consisting of offices or even high-rise buildings.

However, the very terms of these postulated conditions are not consistent. For example, it is inconceivable that institutional and public knowledge of the hazards at the closed disposal facility could be lost under conditions that also allow extensive commercial developments could occur. It is possible that individual homes might be randomly developed at the closed disposal facility if institutional and public knowledge of the hazard is lost. It is not, however, reasonable to assume that broad commercial development of the area would occur under such conditions. Such an assumption must also allow the continuation of (and potentially enhanced) institutional, technical, and cultural practices. If such were the case, the hazards of the closed facility would be encountered and recognized, even if it were assumed that institutional and public knowledge of their existence had been lost.

The possibility remains that individual homes might be constructed at the closed disposal facility lollowing loss of institutional and public knowledge of its hazards. For consistency, this possibility must presume that knowledge of any available financial assurances would also be lost. Thus, if radiation exposures were to occur and personal injury resulted among such inadvertent intruders, there would not be a claim on the resources reserved by the financial assurance plan.

For the reasons stated above, the large-scale development of the closed disposal facility is considered unrealistic. Therefore, no further consideration is given to this activity in this document.

Social or Labor Unrest. In the course of normal facility operations, it is possible that relations could deteriorate with the facility's work force or with the local community. Strikes or demonstrations may be planned to exert pressure on the facility to meet their demands. If relations degrade sufficiently, strikes or demonstrations might produce violence at the disposal facility and cause damage to the facility.

Because these potential losses are expected to be minor compared to the other activities listed in Table 1, this prospect is not considered further in this report. 


\subsection{Potential Financial Losses from Listed Activities}

\subsubsection{Claims from Facility Workers}

Because facility workers are exposed to radiation in the performance of their jobs, this report assumes that they might have a slightly increased risk of cancer. They may also claim other injury that may or may not be related to the operation of and their role at the disposal facility. State laws require that workers be compensated for injury suffered on the job through Workers' Compensation (WC) insurance, which each employer is required to provide.

Until recently, the doctrine of exclusive remedy has limited the awards of injuries claimed under the coverage provided by WC insurance. However, in recent years this doctrine has been rejected in the courts of 32 states, allowing workers to seek additional compensation from their employers. Such claims are frequently covered by the employer liability insurance included in WC policies.

The types of claims from facility workers assumed in this document are summarized in Table 1.

\subsubsection{Onsite Claims}

Potential onsite costs occur when land, building, or disposal units at the facility are damaged or bccome contaminated. Onsite costs also include environmental and compliance monitoring. However, because the NRC requires these activities throughout the operations and institutional control periods, this report addresses only the nonroutine monitoring that might be required if a facility is damaged or becomes contaminated.

The types of potential onsite claims assumed in this document are summarized in Table 1.

\subsubsection{Offsite Claims}

This document assumes that offsite claims will be filed only following an abnormal occurrence at the disposal facility. However, some types of potential offsite claims, such as bodily injury and medical monitoring, are conservatively assumed to not require prool of actual damage to be successful. Other types of potential offsite claims, such as environmental restoration and property damage, are assumed to need quantifiable evidence of damage to determine the level of compensation.

The types of potential offsite claims assumed in this document are summarized in Table 1. 


\section{EVALUATION OF POTENTIAL FINANCIAL LOSSES}

In the preceding chapter, activities were assumed that might result in financial losses to the owner/operator or users of a LLW disposal facility. These activities were identified based on conservative conditions that are unlikely to occur. Identifying the ways in which financial losses might occur is an cssential first step. However, it must be followed by additional steps to characterize these potential losses in a way that facilitates preparing an adequate financial assurance program.

Unlike several other types of facilities, the potential for financial losses after a LLW disposal facility is closed becomes smaller as time passes. This is because most of the radioactivity contained in the waste is short-lived and is constantly decreasing. Financial assurance programs should take into account the decreasing risk posed by a constantly shrinking amount of radioactivity in the waste.

The process of determining the probabilities of occurrence and the magnitudes of potential linancial losses is addressed in the sections of this chapter. Section 3.1 provides an overview of this process. Determining the probabilities of an activity occurring is discussed in Section 3.2. Calculating the probable level of potential losses to workers, onsite damages, and offsite damages is discussed in Sections 3.3, 3.4, and 3.5, respectively. Section 3.6 summarizes and calculates the present value of potential losses.

The application of many elements of the approaches described in this chapter is illustrated in Appendix A, based on the hypothetical facility described in Appendices B and C.

\subsection{Overview of Evaluation Process}

As noted above, identifying the ways potential financial losses might occur is an important step in formulating an effective financial assurance program. Once they have been identified, it is necessary to quantify these potential losses. Ideally, the quantification process would approximate the cost, probability of occurrence, timing, and present value of each potential loss. Each of these characteristics provides information that could be important in determining how to best meet the objectives set for a particular financial assurance program.

Once the potential losses have been characterized, informed decisions can be made to minimize the linancial risks they pose. For example, attention should be given to reducing the probability a linancial loss might occur before attempting to determine how to protect against it. After risk reduction efforts have been completed, the search for financial assurance measures can begin. That is the subject of Chapter 4.

The process of approximating costs and probabilities is described in the sections that follow. General approaches are described in simple terms. In all cases, the costs are estimated as products of numerous factors that bear on specific aspects of each cost.

Although the approaches appear simple, their implementation may be extremely complex. For example, the determination of any probability involves referring to statistical and actuarial data that approximate the risks being evaluated. Data must also be developed on the extent and concentrations of contamination that might be released from the facility in the event of an accident. Such 
determinations require the support of persons with specialized experience in sophisticated computer modeling.

When considering the information presented in the following sections, care must be taken to ensure that the simplicity of the approach does not result in inadequate analyses. Many of the parameters in the various expressions presented in the following sections are complicated functions. For example, the radiation exposure to any member of the general public living near the disposal facility depends on several factors, including the following:

- Location relative to the disposal facility

- Topography of the area

- Material used to shield the radiation source

- Length of the exposure

- Nature of the radiation source (for example, during normal operations, under accident conditions, or following closure).

The importance of each potential loss in formulating a financial assurance program is also influenced by when the loss might occur. Money has a time value that takes into account such factors as inflation and alternate investment opportunities. This means a loss that might occur in the early years of a facility's operating life would have a larger impact on financial assurance planning than a comparable loss that does not occur until 100 years after the facility closes.

\subsection{Evaluating Probabilities of Activities}

Probabilities play a key role in developing a financial assurance program by providing a sense of how likely particular activities are to happen and providing a mechanism to calculate the probable value of potential losses. For example, if an activity actually occurred, the total potential loss would be the same as the probable value of the loss. If, however, an activity had a $50 \%$ likelihood of happening, the probable value of the loss would be $50 \%$ of the total potential loss. The probable value of the activity is calculated by multiplying the probability of the activity by the magnitude of the potential loss. Depending on other characteristics of the potential loss, and the objectives of the linancial assurance plan being developed, both the magnitude and the probable value of the loss can be important.

The following sections describe some approaches for characterizing the probabilities that specific activitics might occur. It should be understood that a variety of other approaches could be used and a specific approach might be difficult to select. Because there is little if any applicable data from the six commcrcial disposal facilities built to date, frequent reference is made to existing statistical and actuarial data bases maintained by industry associations or private companies. In these cases, it might be impossible to find a category that precisely represents an activity at a disposal facility for which the probability is sought. Therefore, experienced judgment must be used to identify a category that is related by specific functional characteristics, even though regulatory requirements for the identified 
category may not be as strict and other differences might exist. Because judgment is involved, there will always be differing opinions about the values chosen.

\subsubsection{Unusual Operating Conditions}

Determining the probabilities of unusual operating conditions depends on the nature of the conditions. If industrial equipment is involved, it is possible to obtain information about the failure of the equipment, the rates at which they are involved in accidents, and the impacts of such accidents.

Relatively little information exists to directly assess the probability of operational accidents at LLW facilities. This is because so few LLW facilities have been built and none have used the highly engineered technologies being designed for the future facilities. Probabilities can, however, be estimated by comparing LLW disposal facilities with other industries that perform similar functions and have a significant body of historical data.

Two basic sources supply information on the probability or relative frequency of industrial accidents. The first is the National Safety Council, which collects information on accident frequencies by industry and type of accident. These frequencies represent the number of accidents per worker, per year. Once a profile is developed of the types of operations that will be performed by workers at the facility, a list can be developed of the functions facility workers will perform. For each function, an assessment can be made of industries with individual activities that are similar to those of the LLW disposal industry. Accident statistics for these activities could then be developed and used to estimate the accident frequency at the LLW disposal facility.

A second source of information on industrial accidents is the National Council of Compensation Insurers (NCCI). The NCCI collects detailed information from insurance companies on workers' compensation claims and settlements. This information is divided by worker classification and accident scverity. Once an assessment is made of the NCCI classifications that most closely match the responsibilities of each worker at the facility, information can be obtained from the $\mathrm{NCCI}$ on the relative probability of accidents for those classifications.

\subsubsection{Extreme Natural Occurrences}

Determining the probabilities of extreme natural occurrences requires historical data and specific onsite information. Examples of extreme natural occurrences that this report assumes might release radioactive contamination into the environment are extreme precipitation or floods, earthquakes, and tornadoes. Because all these perils are insurable to some extent in most industries, insurance claims data are readily available for estimating these probabilities.

\subsubsection{Premature Disposal Unit Failure}

Computer models have been developed to project the behavior of concrete structures in response to degrading environmental influences. These models consider some of the following factors:

- Design characteristics of the structures and the characteristics of the concrete used

- Physical loading specilications to which the structure is built 
- Concentrations of environmental constituents that might cause degradation

- Meteorological conditions that might cause degradation

- Extent of cracking that might give rise to moisture and contaminant migration.

These models can estimate the progressive degradation of the structure until it fails. The migration of moisture and contaminants through the structural materials are estimated concurrently.

It is possible to determine the probability that a structure will fail in any particular year by using a computer technique that develops a probability distribution for the event and selects the probability that is most statistically significant. This technique is called a Monte Carlo simulation and is helpful in determining the probability that financial losses will be associated with the premature failure of disposal units. By using the annual probabilities and cumulative probability of failure, together with the magnitudes of the potential losses, it is possible to determine the probable value of losses associated with a specific activity.

\subsubsection{Trespasser}

One source of data for estimating the probability of a trespasser claim is liability insurance data collected by the Insurance Service Office (ISO). Based on historic information on insurance claims and settlements, ISO calculates the annual insurance rate (premium per 1,000 square feet of area) for policies covering liability claims against owners of vacant buildings. Historically, many of these claims have been made by trespassers.

\subsection{Claims by Workers}

As summarized in Section 2.3, workers might claim bodily injuries as a result of industrial hazards that do not involve radiological hazards. Workers might also claim bodily injury and personal injury as a result of the radiological hazards at the facility. In addition, there might be legal costs incurred as a result of claims associated with facility workers. In this section, possible approaches to estimating the magnitudes and probabilities of these potential losses are presented.

Although the potential losses described above might not be completely covered by WC insurance policies, they would be processed in conjunction with such claims. Employer liability provisions are conventionally bundled with WC insurance policies and may offer additional protection to employers under certain conditions.

\subsubsection{Bodily Injury to Workers from Industrial Hazards}

During normal disposal operations and in unusual situations, there are numerous hazards that have nothing to do with the presence of radioactive waste at the facility and involve only conventional industrial equipment and activities. It is assumed that workers might suffer bodily and personal injuries as a result of these industrial hazards. Under normal conditions, or at a conventional facility, claims of such injury would be compensated through the WC insurance that each employer must provide. 
Because the industrial hazard is not a function of the radioactive material at the facility, it is assumed that adequate coverage against potential losses is provided by WC insurance. Therefore, there is no need for financial assurance beyond that provided to the employer by WC insurance. Under individual conditions, such a conclusion might not be supportable. In such a case, consideration should be given to providing additional financial assurance.

\subsubsection{Bodily Injury to Workers from Radiological Hazards}

Because several workers at a disposal facility might be exposed to radiation, they may have a slightly increased risk of contracting cancer during their lifetimes. The EPA has developed a relationship between the cumulative radiation dose workers might receive at the disposal facility and their increased risk of developing fatal cancer. This relationship is given by:

$\mathrm{WR}=\mathrm{WD} \times \mathrm{RF}$

where

$$
\begin{aligned}
& \mathrm{WR}=\text { risk of cancer among disposal facility workers } \\
& \mathrm{WD}=\begin{array}{l}
\text { cumulative radiation dose received by all facility workers over the facility operating } \\
\text { life }
\end{array} \\
& \mathrm{RF}=\text { risk factor. }
\end{aligned}
$$

This expression is inherently probabilistic, because of the epidemiological basis upon which it was developed.

If a worker develops cancer, and the cancer is shown to be caused by the radiation exposure received at the disposal facility, it is assumed that the worker would receive compensation under WC insurance. Furthermore, it is assumed that the worker files a suit under employer liability provisions of WC insurance policies, for which he may receive additional compensation. Using Equation (3-1) and the information presented in this paragraph, the cost of bodily injury to workers as a result of the radiological hazard at the facility is expressed as:

$$
\mathrm{WRC1} \$=\mathrm{WD} \times \mathrm{RF} \times \mathrm{WCS} \times \mathrm{WSC} \times \mathrm{WC}
$$

where

$$
\begin{aligned}
& \text { WRC1\$ }=\text { probable cost of claims by workers } \\
& \text { WD } \quad=\text { cumulative dose received by all facility workers over the facility operating lifetime } \\
& \mathrm{RF} \quad \text { risk factor } \\
& \text { WCS } \quad=\begin{array}{l}
\text { probability a worker will file a suit for compensation beyond WC insurance } \\
\text { coverage }
\end{array}
\end{aligned}
$$


WSC $=$ probability the suit will be successful

WC\$ = additional compensation awarded that exceeds limits of employer liability coverage provided with WC insurance.

The values of these parameters can be determined from nationwide data bases using the cumulative worker dose received for the probabilities and the amount of compensation beyond WC insurance coverage. Worker doses are estimated using extensive data bases that describe the activities workers perform and the radioactive contents of waste containers to which workers are exposed. Computer models estimate the level of radiation exposure in each situation, all of which are summed to determine the cumulative worker exposure.

An alternative approach ignores the radiation dose actually received by workers in estimating the cost of bodily injury to workers as a result of the radiation exposure. Instead, if a worker contracts cancer, it is assumed to be caused by radiation received at work. Because the incremental risk of cancer from working at a LLW disposal facility is much smaller than the risk of cancer from all other causes, this approach conservatively overestimates the impact of radiation to facility workers. With the increasing cost of litigation, this approach might prove more cost effective and much simpler to implement.

The cost is conservatively estimated using the following relation:

$\mathrm{WRC} 2 \$=\mathrm{WN} \times \mathrm{PFC} \times \mathrm{WSC} \times \mathrm{WCS} \times \mathrm{WCS}$

where

$$
\begin{aligned}
& \text { WRC2\$ }=\text { probable cost of claims by workers } \\
& \text { WN }=\text { number of workers at disposal facility } \\
& \text { PFC }=\text { Irequency of cancer from all causes among public } \\
& \text { WSC }=\text { probability that worker with cancer will file suit } \\
& \text { WCS }=\text { probability of success for worker filing suit for cancer } \\
& \text { WC } \$=\begin{array}{l}
\text { additional compensation for cancer beyond employer liability coverage provided } \\
\text { with WC insurance. }
\end{array}
\end{aligned}
$$

The probabilities and amounts of additional compensation can be determined by referring to legal and insurance industry data bases.

\subsubsection{Personal Injury to Workers from Radiological Hazards}

Activities and hazards at the disposal facility might be blamed for "fear, phobias, and extreme mental and emotional concern." Such conditions have been used as a basis for claims of personal 
injury liability, resulting in financial losses to the facility owner/operator and users through either a negotiated settlement or a judgment of a court of law.

It is difficult to quantify the cause of personal injury. No direct relationship exists to relate the possibility of personal injury to the hazards associated with radioactive waste management activities. Therefore, reference might be made to claims experienced in a variety of industries to determine the probabilities that such claims might be made, the likelihood of monetary payments, and the magnitudes of such payments. This information might be used as follows to quantify the potential losses that might result from claims of personal injury among facility workers:

WRP\$ $=W N \times W S P \times W P S \times W P \$$

where
WRP\$ $=$ probable cost of personal injury claims by workers
WN $=$ number of workers at the disposal facility
WSP $=$ probability that worker will file suit claiming personal injury
WPS $=$ probability of success for worker filing suit for personal injury
WP\$ = additional compensation for personal injury beyond employer liability coverage provided with WC insurance.

The probabilities and amounts of additional compensation can be determined by referring to legal and insurance industry data bases.

\subsubsection{Legal Costs Resulting from Workers' Claims}

Because many of the claims described in this section involve negotiations or litigation, legal defense costs will also be incurred. In general, the costs of such defense can be estimated by determining the number of cases where legal services are required and the average cost of legal services per case. For costs associated with workers' claims, the costs can be estimated by:

$\mathrm{WLD} \$=\mathrm{WN} \times \mathrm{PFC} \times \mathrm{WSC} \times \mathrm{WSP} \times \mathrm{WLC} \$$

where

WLD\$ = probable cost of legal defense against all claims by workers

$\mathrm{WN}=$ number of workers at disposal facility

PFC $=$ frequency of cancer from all causes among public

WSC $=$ probability that worker with cancer will file suit 


$$
\begin{aligned}
& \text { WSP }=\text { probability that worker will file suit claiming personal injury } \\
& \text { WLC\$ }=\text { cost of legal defense per case filed for workers' claims. }
\end{aligned}
$$

The probabilities and amounts of compensation can be determined by referring to legal and insurance industry data bases.

\subsection{Onsite Losses}

In addition to the potential claims for worker injuries, this report assumes that other types of onsite losses might be caused by unusual operating conditions, extreme natural occurrences, or unacceptable performance of disposal units. If such an activity were to occur, compliance monitoring, decontamination of onsite facilities, and remedial action of the failed disposal unit would be undertaken immediately. Determining the potential costs for these types of actions is discussed in the following sections.

\subsubsection{Additional Environmental and Compliance Monitoring}

If there were reason to believe that an environmental medium had been contaminated or that regulatory limits were not being met, additional regulatory compliance monitoring might be required. Additional monitoring might also be necessary to provide assurance that the public health and environment are not at risk. Such monitoring would require installing additional groundwater monitoring wells and collecting more environmental media samples for analysis. The costs of additional monitoring activities can be estimated as:

$$
\mathrm{MS} \$=(\mathrm{MW} \times \mathrm{MWI})+(\mathrm{MNS} \times \mathrm{MC} \$ \mathrm{YENV})
$$

where

$$
\begin{aligned}
& \text { MS\$ }=\text { cost of environmental/compliance monitoring } \\
& \text { MW }=\text { feet of monitoring well to be installed } \\
& \text { MWI\$ }=\text { cost per foot of monitoring well installation } \\
& \text { MNS }=\text { Number of environmental samples to be collected and analyzed each year } \\
& \text { MC\$ }=\text { cost of collecting and analyzing environmental samples } \\
& \text { YENV }=\text { number of years environmental samples must be collected and analyzed. }
\end{aligned}
$$

The cost of installing wells depends on their depth, the medium in which the well must be installed, and the type of well. The required sampling might involve groundwater, surface water, sediments, soils, vegetation, and air. The cost to collect more samples will be a composite that reflects these various media for which each must be analyzed. 


\subsubsection{Decontamination of Onsite Facilities}

In the event of unusual operating conditions or extreme natural events, it is possible that land and buildings within the disposal facility boundaries might be contaminated. The extent of decontamination activities depends upon the type and level of contamination and the facilitics involved. For land decontamination, assuming simple surface contamination, the following expression can be used to estimate the cost:

$\mathrm{OL}=\mathrm{OL} \times \mathrm{LD} \$$

where

$$
\begin{aligned}
& \text { OL\$ } \quad=\text { cost of decontaminating onsite land area } \\
& \text { OL } \quad=\text { acres of contaminated onsite land area } \\
& \text { LD\$ } \quad=\text { cost per acre to decontaminate land areas. }
\end{aligned}
$$

Where buildings are involved, the costs can also be related primarily to the area of contaminated structures. In this case,

$\mathrm{OB} \$=\mathrm{BA} \times \mathrm{BD} \$$

where

$$
\begin{aligned}
& \mathrm{OB} \$ \quad \text { cost of onsite building decontamination } \\
& \mathrm{BA} \quad=\text { square feet of contaminated onsite building floor area } \\
& \mathrm{BD} \$ \quad=\text { cost per square foot of floor area to decontaminate onsite buildings. }
\end{aligned}
$$

The extent of contamination caused by unusual operating conditions or extreme natural occurrences must be estimated by computer modeling. These techniques project how much contaminant left the disposal facility and where it went. Greater levels of contamination would be found close to and downwind from the facility. Prior to decontamination, these projections would be checked by onsite contamination surveys. The cost of decontamination depends on the actual level of contamination at cach location.

\subsubsection{Remedial Action for Failed Disposal Units}

In the event that disposal units do not perform as required, remedial action might be necessary. This would likely include:

- Repair or replacement of failed disposal units

- Removal and relocation of disposed waste 
- Removal and treatment of contaminated groundwater.

All of the remedial action options are difficult to quantily without site- and lacility-specilic intormation. Generalizations can be made, but reasonably accurate estimates can only result if prepared on a specific basis. Thus, no approach, other than specially prepared engineering estimates, is suggested for quantifying these potential losses.

\subsection{Offsite Losses}

For the purposes of this report, if an activity occurred that caused the release of radioactive materials to areas around a disposal facility, potential offsite losses are assumed to result from claims of bodily and personal injury, property damage, economic losses, medical monitoring, environmental restoration, and the legal costs of settling the claims. This section describes some approaches to estimating the magnitudes of these potential losses.

\subsubsection{Claims of Bodily Injury to Members of the General Public}

If radioactive materials were released from the disposal facility, a few members of the general public might be affected. As described in Section 3.3.2, it is possible to estimate the dose received by such persons and the resulting cancer risk. The probable cost of compensation to such persons could be determined using the following equation:

$\mathrm{PRC} 1 \$=\mathrm{RF} \times \mathrm{PD} \times \mathrm{PSC} \times \mathrm{PCS} \times \mathrm{PC} \$$

where

$$
\begin{aligned}
& \text { PRC1\$ } \\
& \text { RF } \quad=\text { probable cost of compensation to public from cancer } \\
& \text { PD } \quad=\text { estimated cumulative radiation dose to public } \\
& \text { PSC } \quad=\text { probability that public with cancer will file suit } \\
& \text { PCS } \quad=\text { probability of success for public filing suit for cancer } \\
& \text { PC\$ } \quad=\text { compensation for cancer. }
\end{aligned}
$$

The dose received by members of the general public can be estimated using site-, facility-, waste-, and incident-specilic information. Computer models are needed to estimate the transport of radioactive materials through the atmosphere and to determine the radiation exposure that the gencral public might receive. Legal and insurance industry data bases can be used to determine the probabilities and amounts of additional compensation of similar cases.

Alternatively, it might be assumed that all cancers developed by potentially exposed members of the general public are attributable to the presence of the facility. In this case, the incidence of 
cancer among the persons residing near the facility can be assumed to be the same as for the population as a whole. With the number of fatal cancers estimated, a cost can be associated:

$\mathrm{PRC} 2 \$=\mathrm{PN} \times \mathrm{PFC} \times \mathrm{PSC} \times \mathrm{PCS} \times \mathrm{PC} \$$

where

$$
\begin{aligned}
& \text { PRC2\$ } \\
& \text { PN } \quad \text { probable cost of claims by public } \\
& \text { PFC } \quad=\text { frequency of cancer from all causes among public } \\
& \text { PSC } \quad=\text { probability that members of public with cancer will file suit } \\
& \text { PCS } \quad=\text { probability that suit for cancer in public will be successful } \\
& \text { PC\$ } \quad=\text { compensation for cancer. }
\end{aligned}
$$

The probabilities and amounts of compensation can be determined by referring to legal and insurance industry data bases.

\subsubsection{Claims of Personal Injury to Members of the General Public}

It is assumed that personal injury claims might be made by members of the general public who are distressed at the presence of or by releases from the disposal facility. No direct relationship exists to relate the possibility of personal injury to the hazards associated with radioactive waste management activities. Therefore, one basis for estimating the cost of this possibility is the claims experience from other industries. With this approach, the costs might be estimated as:

$$
P R P \$=P N \times P S P \times P P S \times P P \$
$$

where

$$
\begin{aligned}
& \text { PRP\$ } \quad=\text { probable cost of personal injury claims by public } \\
& \text { PN } \quad=\text { population near the disposal facility } \\
& \text { PSP } \quad=\text { probability that public will file suit claiming personal injury } \\
& \text { PPS } \quad=\text { probability of success for public filing suit for personal injury } \\
& \text { PP\$ } \quad=\text { compensation for personal injury. }
\end{aligned}
$$

The probabilities and amounts of compensation can be determined by referring to legal and insurance industry data bases. 


\subsubsection{Claims of Property Damage}

Claims of property damage may involve land areas and buildings that are contaminated and require remediation. The costs for decontaminating land areas might be estimated using:

$\mathrm{PDL} \$=\mathrm{PL} \times \mathrm{LD} \$$

where

PDL $\$=$ cost of decontaminating offsite land areas

$\mathrm{PL} \quad=$ acres of contaminated offsite land area

LD\$ $=$ cost of decontaminating land area per acre.

The costs of decontaminating offsite buildings might be estimated with this relationship:

$\mathrm{PDB} \$=\mathrm{PB} \times \mathrm{BD} \$$

where

PDB $\$=$ cost of decontaminating offsite buildings

$\mathrm{PB}=$ floor area in offsite buildings requiring decontamination (square feet)

BD\$ = cost to decontaminate buildings per square foot of floor area.

As with onsite land areas and buildings, it is necessary to project the extent and concentration of contamination using computer codes designed to estimate the transport of radioactive materials through the atmosphere. These codes project how much contaminant leaves the disposal facility and how far it travels. Land closer to and downwind from the facility will generally be subject to greater levels of contamination than will those farther away or upwind. The per-acre and per-square-foot costs of decontamination should be determined using information about the extent of the necessary decontamination effort and the land area and buildings to be decontaminated.

\subsubsection{Claims of Economic Losses}

It is assumed that economic losses might be claimed as a result of accidental releases from the disposal facility. These losses might take the form of lost production, lost ability to market goods, and decreased property value for land and buildings. For lost production the potential loss might be expressed as:

PEP\$ $=$ PLP $\times$ PLP\$ $\times$ YPROD $\times$ PSL $\times$ PLS 
where

PEP\$ = probable cost of lost production suffered by public

PLP $=$ annual quantity of lost production

PLP\$ = cost of lost production per unit of quantity

YPROD $=$ number of years of lost production

PSL = probability that public will file suit for lost production

PLS = probability that suits for lost production will be successful.

The potential loss of lost marketability can be represented as:

$\mathrm{PEM} \$=\mathrm{PLM} \times \mathrm{PLM} \$ \times \mathrm{YMARK} \times \mathrm{PSM} \times \mathrm{PMS}$

where

PEM $\$=$ probable cost of lost marketability suffered by public

PLM = annual quantity of lost marketability

PLM $\$=$ cost of lost marketability per unit of quantity

YMARK $=$ number of years of lost marketability

PSM $=$ probability that public will file suit for lost marketability

PMS = probability that suits for lost marketability will be successful.

Potential losses resulting from alleged or actual declines in land values can be estimated using:

PDVL\$ $=$ PDVL $\times$ DL $\$ \times$ PSV $\times$ PVS

where

PDVL\$ = probable cost of devalued land area

PDVL $=$ acres of land with depressed value

DL $\$=$ amount of value loss per acre with depressed value

PSV $=$ probability that public will file suit for depressed value

PVS $=$ probability that suits for depressed value will be successful. 
The potential losss of alleged or actual decreased building value may be found through:

PDVB\$ $=$ PDVB $\times$ DB $\$ \times P S V \times P V S$

where

PDVB $\$=$ probable cost of devalued buildings

PDVB $=$ square feet of floor area of buildings with depressed value

$\mathrm{DB} \$=$ amount of value lost per square foot of floor area with depressed value

PSV $=$ probability that public will file suit for depressed value

PVS $=$ probability that suits for depressed value will be successful.

The quantities of lost production or marketability and the extent of claimed devaluation must be determined using facility-specific information. The probabilities and amounts of additional compensation can be determined by referring to legal and insurance industry data bases.

\subsubsection{Costs of Medical Monitoring for the General Public}

Facility owners or operators may be required to pay for medical monitoring of those living within a given distance of the disposal site. The magnitude of these costs depends upon the number of persons whose health must be monitored, the cost of such monitoring, and the number of years during which the monitoring is performed. The cost of medical monitoring can be estimated as:

$\mathrm{PM} \$=\mathrm{PN} \times \mathrm{PMM} \$ \times \mathrm{YMED}$

where

$$
\begin{aligned}
& \text { PM\$ }=\text { cost of medical monitoring } \\
& \text { PN }=\text { population near the disposal facility } \\
& \text { PMM\$ }=\text { annual cost of medical monitoring per person } \\
& \text { YMED }=\text { number of years medical monitoring is provided. }
\end{aligned}
$$

The number of persons requiring annual medical checkups depends on the population density of the area around the facility. The cost of annual monitoring can be determined by referring to legal and insurance industry data bases. 


\subsubsection{Legal Defense Costs}

Associated with the potential for offsite claims is the potential legal delense cost. This cost would depend on the number of cases that must be negotiated or adjudicated. The following cxpression provides a means of estimating the legal defense costs:

$\mathrm{PLD} \$=[(\mathrm{PN} \times \mathrm{PFC} \times \mathrm{PSC})+(\mathrm{PN} \times \mathrm{PSP})+\mathrm{NPD}+\mathrm{NEL}+\mathrm{NDV}] \times \mathrm{PLC} \$$

where

$$
\begin{aligned}
& \text { PLDS } \quad=\text { probable cost of legal defense against all claims by the public } \\
& \text { PN } \quad=\text { population near the disposal facility } \\
& \text { PFC } \quad=\text { frequency of cancer from all causes among public } \\
& \text { PSC } \quad=\text { probability that public with cancer will file suit } \\
& \text { PSP } \quad=\text { probability that public will file suit claiming personal injury } \\
& \text { NPD } \quad=\text { number of property (land and buildings) damage claims } \\
& \text { NEL }=\text { number of claims of economic losses } \\
& \text { NDV }=\text { number of claims of property devaluation } \\
& \text { PLC\$ } \quad \text { cost of legal defense per case filed for public claims. }
\end{aligned}
$$

The probabilities and cost per case can be determined by referring to legal and insurance industry data bases.

\subsubsection{Cost of Environmental Restoration}

It is assumed that if an activity at the disposal facility causes environmental damage, regulatory agencies or courts might order environmental restoration at the expense of the disposal facility. This restoration might involve cleanup of groundwater systems, surface water systems, soil, vegetation, wildlife habitat, and other natural resources. Some costs already discussed (e.g., decontamination of offsite land areas and buildings) may also be considered environmental restoration costs.

The cost of such restoration activities is highly dependent upon their nature and extent. Therefore, an engineering cost estimate is suggested that identifies and quantifies the nature and extent of required remediation.

\subsection{Determining the Present Value of Potential Losses}

The process of quantifying the amounts and probabilities of potential financial losses was described in Sections 3.2 through 3.5. When this information is combined with estimates of when 
losses might occur, the present value of potential losses can be determined. Present value information is important in:

- Planning loss prevention/minimization efforts

- Ensuring lunds are available on a timely basis

- Using the financial assurance plan's resources efficiently.

As noted earlier, money has a time value that takes into account such factors as inflation and alternate investment opportunities. This means a loss that might occur in the early years of a facility's operating life would have a larger impact on planning financial assurances than a comparable loss that might not occur until 100 years after the facility closes. The following standard equation is used to determine the present value of a potential future cost:

$P V=F V(1+I R)^{-T}$

where

$$
\begin{aligned}
& \mathrm{PV}=\text { present value } \\
& \mathrm{FV}=\text { future value } \\
& \mathrm{IR}=\text { investment rate } \\
& \mathrm{T}=\text { time. }
\end{aligned}
$$

Using this formula, if a loss were to occur 15 years in the future and would cost approximately $\$ 50,000$, its present value would be about $\$ 34,523$ when invested at a rate of $2.5 \%$ per year above inllation. Based on this information, the financial assurance plan might call for $\$ 35,000$ to be put into an account earning at least $2.5 \%$ interest above the inflation rate to ensure the $\$ 50,000$ would be available in 15 years. In contrast, if the loss were not to occur until 100 years after closure (in 135 years), the amount needed would only be $\$ 1,783$. 


\section{STRUCTURING A FINANCIAL ASSURANCE PROGRAM}

In the previous chapters, broad categories of potential losses were identified together with examples of activities that might cause them. Also, this report has discussed how some characteristics of these losses might be evaluated. This chapter summarizes some ways the needs of a financial assurance program might be met. Terms peculiar to the insurance and risk management professions are defined in the Glossary (Appendix D).

\subsection{Summary of Financial Assurances}

As discussed in Chapters 2 and 3, potential losses assumed in this report can be divided into three groups:

- Claims by workers for bodily and personal injury

- Onsite property losses

- Claims by the general public for bodily and personal injury, property damage, and economic losses.

Claims by workers are routinely protected through the purchase of traditional Workers' Compensation insurance policies. These policies would be purchased during the operating phase of the disposal facility through traditional insurance sources such as brokers or direct writers. Because the insurance is written on an "occurrence" form, it covers losses that might result from activities during the operating phase of the facility, even if those losses do not appear for several years in the future. Therefore, the cost of WC insurance can be identified and charged directly to waste generators through the disposal fee.

Some worker claims may arise that exceed coverage provided by WC policics. These may be covered by cmployer liability insurance, which is generally written in connection with WC coverage. Strict limits apply to this coverage. Therefore, additional financial assurance is advisable, because employer liability insurance may be inadequate to meet the potential demands that exceed WC coverage.

Coverage for onsite losses is much more difficult, since it is not currently available from insurers. Therelore, such protection would need to be obtained through other means, most notably through self-insurance.

Offsitc liability protection is necessary for losses caused or alleged to have been caused to property or persons who are not employees of the facility. Although this type of loss is unlikely, it has the potential to be financially disabling and therefore requires special consideration. Offsite liability insurance for LLW disposal facilities is available from only one source and is limited to $\$ 25$ million. Any need for protection beyond that limit could be met through self-insurance.

Self-insurance has two important dimensions that should be considered when applied to LLW disposal facilitics: 
- Is cach facility self-insured individually or self-insured through an insurance pool?

- Is the self-insurance prefunded or postfunded?

Prefunding means collecting funds prior to a loss. Postfunding means collecting the necessary funds after the loss has occurred. In practice, prefunding and postfunding are often used in combination to cover various aspects of potential losses.

Factors that should be considered in designing a plan to provide financial assurances for LLW disposal facilities include the following:

- Financially disabling losses are extremely improbable

- Insurance is not available to provide coverage for all potential losses

- Financial assurances should be financially efficient (i.e., do not commit large amounts of capital to nonproductive purposes).

The information presented in Sections 4.2 through 4.5 is summarized in Table 2, together with a brief cvaluation of each financial assurance mechanism. The table indicates that insurance is available only to protect against potential claims by workers and the general public.

Generally speaking, individual self-insurance is easy to implement, while pooled self-insurance presents obstacles because of the diversity of the organizations involved. Prefunding arrangements provide greater assurance than postfunding. However, this assurance comes at the expense of financial efficiency and is an economic burden to generators for losses that might never occur.

\subsection{Currently Available Insurance for Onsite and Offsite Losses}

\subsubsection{Description}

Insurance is a financial arrangement where one party, recognized and licensed to do so by the states, agrees to compensate another party for a loss if it results from a specified activity. Insurance may also be defined as a device for reducing financial risks by combining a sufficient number of similar potential losses to make the losses statistically predictable. The predictable loss is then shared proportionately by all who might be insured.

Insurance is typically purchased to protect against several potential losses, including:

- Injury to workers

- Damage to onsite structures and land

- Injury to the public

- Damage to public structures and land. 
Table 2. Summary of available financial assurance mechanisms.

\begin{tabular}{|c|c|c|c|}
\hline $\begin{array}{l}\text { Coverage } \\
\text { required }\end{array}$ & $\begin{array}{l}\text { Assurance } \\
\text { option }\end{array}$ & $\begin{array}{l}\text { Funding } \\
\text { option }\end{array}$ & Comments \\
\hline \multirow[t]{2}{*}{ Worker Claims } & $\begin{array}{l}\text { Workers' Compensation } \\
\text { Insurance }\end{array}$ & $\overline{-}$ & $\begin{array}{l}\text { Required by law } \\
\text { Readily available up to limits of coverage }\end{array}$ \\
\hline & $\begin{array}{l}\text { Employer's Liability } \\
\text { Insurance }\end{array}$ & - & $\begin{array}{l}\text { May cover workers' claims in excess of Workers' Compensation } \\
\text { insurance } \\
\text { Strict limits on coverage }\end{array}$ \\
\hline \multirow[t]{6}{*}{ Potential Onsite Losses } & $\begin{array}{l}\text { Self Insurance - } \\
\text { Alone }\end{array}$ & Prefunded & $\begin{array}{l}\text { Relatively easy to implement } \\
\text { Potentially economically burdensome to generators } \\
\text { Economically inefficient } \\
\text { Useful for burning layer }{ }^{\mathbf{a}}\end{array}$ \\
\hline & $\begin{array}{l}\text { Self Insurance - } \\
\text { Pooled }\end{array}$ & Prefunded & $\begin{array}{l}\text { Relatively difficult to implement } \\
\text { Potentially economically burdensome to generators } \\
\text { Economically inefficient } \\
\text { Useful for burning layer }\end{array}$ \\
\hline & $\begin{array}{l}\text { Self Insurance - } \\
\text { Alone }\end{array}$ & Postfunded & $\begin{array}{l}\text { Relatively easy to implement } \\
\text { Economically attractive to generators } \\
\text { Economically efficient } \\
\text { Useful for excess layer } \\
\text { Uncertain source of future funds }\end{array}$ \\
\hline & $\begin{array}{l}\text { Self Insurance - } \\
\text { Pooled }\end{array}$ & Postfunded & $\begin{array}{l}\text { Relatively difficult to implement } \\
\text { Economically attractive to generators } \\
\text { Economically efficient } \\
\text { Useful for excess layer }{ }^{\mathbf{a}} \\
\text { Uncertain source of future funds }\end{array}$ \\
\hline & Surety Bond & - & $\begin{array}{l}\text { Limited utility because of long life of potential risk } \\
\text { Recovers losses only from the insured(s) }\end{array}$ \\
\hline & Financial Guarantees & - & $\begin{array}{l}\text { Limited utility because of long life of potential risk } \\
\text { Directly commits resources of the insured }\end{array}$ \\
\hline
\end{tabular}


Table 2. (continued).

\begin{tabular}{|c|c|c|c|}
\hline $\begin{array}{l}\text { Coverage } \\
\text { required }\end{array}$ & $\begin{array}{l}\text { Assurance } \\
\text { option }\end{array}$ & $\begin{array}{l}\text { Funding } \\
\text { option }\end{array}$ & Comments \\
\hline \multirow[t]{7}{*}{ Potential Offsite Losses } & Insurance & - & $\begin{array}{l}\text { Easy to implement } \\
\text { Currently available to } \$ 25 \text { million } \\
\text { Useful for burning layer }{ }^{2}\end{array}$ \\
\hline & $\begin{array}{l}\text { Self Insurance - } \\
\text { Alone }\end{array}$ & Prefunded & $\begin{array}{l}\text { Relatively easy to implement } \\
\text { Potentially economically burdensome to generators } \\
\text { Economically inefficient } \\
\text { Useful for burning layer }\end{array}$ \\
\hline & $\begin{array}{l}\text { Self Insurance - } \\
\text { Pooled }\end{array}$ & Prefunded & $\begin{array}{l}\text { Relatively difficult to implement } \\
\text { Potentially economically burdensome to generators } \\
\text { Economically inefficient } \\
\text { Useful for burning layer }^{\mathrm{a}}\end{array}$ \\
\hline & $\begin{array}{l}\text { Self Insurance - } \\
\text { Alone }\end{array}$ & Postfunded & $\begin{array}{l}\text { Relatively easy to implement } \\
\text { Economically attractive to generators } \\
\text { Economically efficient } \\
\text { Useful for excess layer } \\
\text { Uncertain source of future funds }\end{array}$ \\
\hline & $\begin{array}{l}\text { Self Insurance - } \\
\text { Pooled }\end{array}$ & Postfunded & $\begin{array}{l}\text { Relatively difficult to implement } \\
\text { Economically attractive to generators } \\
\text { Economically efficient } \\
\text { Useful for excess layer } \\
\text { Uncertain source of future funds }\end{array}$ \\
\hline & Surety Bond & - & $\begin{array}{l}\text { Limited utility because of long life of potential risk } \\
\text { Recovers losses only from insured(s) }\end{array}$ \\
\hline & Financial Guarantees & - & $\begin{array}{l}\text { Limited utility because of long life of potential risk } \\
\text { Directly commits resources of the insured }\end{array}$ \\
\hline
\end{tabular}

a. Defined in Glossary (Appendix E). 
Insurance accomplishes several risk management activities that are essential elements of a financial assurance program at LLW disposal facilities, namely:

- Transferring potential loss to someone else, up to the limit of the policy

- Transferring obligations of claims handling, claims settlement, and legal defense to an organization that is expert in those matters

- Limiting the insured's cost of a potential loss to that of premium payments.

Large, traditional insurance companies also have sufficient capital and cash flow capabilities to be as financially efficient as possible. Because insurance companies spread their losses over many different types of risks, the principles of statistics work in their favor. Thus, the insurance industry would only need, in an ideal situation, to collect enough premiums to pay the actual losses at all LLW disposal facilities, plus the insurance company's overhead (acquisition costs, claims handling costs, taxes, and other overhead) and profit. They would not need to collect substantial additional premiums for potential deviations from the probable value of potential losses because they would be paid by premiums collected from other lines of insurance.

\subsubsection{Applicability}

Insurance companics do not offer liability insurance for onsite losses because of the difficulty in distinguishing between contamination caused by proper disposal of LLW and contamination caused by activities such as those described in Chapter 2 . Although liability insurance is not currently available for onsite losses, it is available for offsite losses with specific restrictions. Traditional insurance could be an effective way to provide the needed financial assurance against potential oflsite liability losses of up to $\$ 25$ million.

\subsubsection{Availability}

Currently, the only available source of offsite liability insurance for LLW disposal facilities is American Nuclear Insurers (ANI, a consortium of traditional insurance companies). The ANI policy is continuous and covers any losses that occur during the active period of the contract and reported within 10 years of the policy cancellation (10-year discovery period). Historically, disposal facilities have opted to continue their coverage at reduced premium in the post-closure period to cover any occurrences in that period. By continuing coverage, the 10 -year discovery period is kept open and the facility would continue to be protected against potential offsite claims.

The ANI policy is "site-specific" and "omnibus." Site-specific refers to covering only those activities at a designated site and it is rated based on the specific attributes of that site; one policy does not cover more than one location. The coverage is omnibus in that it indemnifies the facility operator and any additional interests who might be held legally liable for property damage and bodily injury by the public. The limit of liability is a lifetime total that includes indemnity and legal costs. ANI can reinstate coverage for future claims (not the same claim) at its own discretion.

Other insurance sources may decide to compete with ANI. However, ANI is a consortium of many traditional insurance companies with vast resources. Therefore, it would be difficult, if not 
impossible, to assemble an alternate consortium of insurance companies even if the resources of the worldwide insurance market were used. Thus, LLW disposal facilities that choose to purchase offsite liability insurance are dependent upon the continued willingness of traditional insurance companies to provide capability and coverage through the ANI consortium.

In 1987, ANI instituted a moratorium on coverage for new LLW disposal facilities to strengthen the language in its policies and to affirm the scope of coverage as strictly offsite coverage for sudden and accidental liabilities. The suspension was caused by expanding environmental liabilities in general and a dispute over coverage limitations, as illustrated in the Maxey Flats litigation. Maxey Flats is a LLW disposal facility identified as a priority Superfund cleanup site. The facility operator has asserted that the ANI policy should cover onsite response and cleanup costs. ANI has vigorously insisted that its policy was designed to cover a client's legal liability for offsite property damages and bodily injury, not damages at the client's facility. On January 1,1990, ANI ended its moratorium and is currently offering coverage up to a limit of $\$ 25$ million for new LLW facilities.

General environmental liability insurance policies are difficult to secure, despite the large demand by U.S. industry for protection against liability suits alleging offsite pollution. In fact, environmental impairment liability (EIL) insurance is available almost exclusively through the American International Group (AIG) and Reliance Insurance Company. Their policies have several restrictive provisions, including a specific exclusion of any nuclear-related activities. AIG's policy will cover up to $\$ 20$ million in aggregate coverage for both sudden and accidental and gradual pollution only for claims made during the active period of the policy (claims-made insurance). Newcomers to the field, like the St. Paul Companies, Inc., and the Underwriters at Lloyd's of London, are offering more limited coverage. With little competition in the area of EIL insurance, the market remains extremely tight.

A variety of insurance experts (clients, brokers, and insurers) surmise that many potential clients are simply not attracted by available EIL insurance because of unfavorable terms (i.e., low limits and high costs). Most continue the practice of going bare (not maintaining insurance) or self-insuring. Finally, traditional EIL insurance policies do not cover onsite losses, although this may be changing.

Traditional insurance companies might be attracted to the possibility of providing insurance for the LLW disposal industry because it possesses several attributes that insurance companies look for in the current marketplace:

- It represents a new insurance market

- There is a sizeable dollar value of potential insurance to be sold

- Disposal facilities appear to be reasonably predictable in terms of potential losses; therefore, insurance for these could be profitably priced

- There is an opportunity to generate a large investment income from reserves held for potential losses that have a very low probability of happening and would be payable at some time in the distant future. 
However, there are two major issues related to this type of insurance that make it unlikely that traditional insurance would be available at a reasonable cost. First, insurance companies have had very unfavorable experiences in areas relating to environment and health. For example, the insurance industry has greatly reduced the coverage for pollution-related claims since 1973. Despite the insurance companies' apparent attempts to reduce coverage for environmentally related claims, they have still suffered large losses. They have also had insurance exclusions interpreted much more broadly by the courts than was intended. Thus, insurance industry executives are reluctant to pursue new insurance markets for environmental hazards, despite the apparently large profit potential.

Second, insurance companies normally pursue markets where there is substantial opportunity for investment income by providing coverage where the premium would be collected well in advance of potential losses. However, the rapidly changing legal and social atmosphere has caused insurance companies to be reluctant to pursue such long-term coverages despite the best efforts of highly qualified insurance experts to predict the cost of future potential losses.

Because of the insurance industry's reluctance to provide pollution insurance, there has been substantial growth in the private insurance market. Total expenditures for these alternative mechanisms (for all types of coverage in all markets) have grown from about $\$ 30$ billion in 1980 to $\$ 55$ billion in 1989 . The attraction has been the availability of coverage, increased coverage (or less limitation on coverage), and lower prices.

Foreign insurers may be interested in the risk, but typically, foreign insurers are quite concerned about the broad legal interpretations of the U.S. court system and the ability of the courts to override exclusions that insurance companies believe are very explicit. Therefore, foreign insurance companies probably will not be attracted to the U.S. market at reasonable premiums.

\subsubsection{Rating/Premium Costs}

In determining policy rates for LLW disposal facilities, underwriters would consider several factors such as the following:

- Volume of the waste

- Radioactivity of the waste

- Natural characteristics of the site

- $\quad$ Engineered structures

- $\quad$ Procedures for operation, closure, and postclosure of the facility.

Insurance rate-making is founded on historical data to estimate loss costs and expenses for a class of potential losses. Past experience can be modified and trended to provide enough funding to pay the potential losses, cover related expenses, and produce a profit to the insurer for its risk-taking.

Because of the relative newness of the environmental insurance area, the uncertainty caused by various court decisions, and the associated expansions of coverage by the courts, it is difficult for 
insurers to price coverage attractively, if they choose to make it available. Therefore, insurance prices are volatile and reflect the high margin of risk assumed by the insurer. The lack of data from actual claims and the financial implications of potential losses explain the lack of a conventional insurance market for nuclear-related activities.

\subsubsection{Limiting Conditions}

ANI currently offers liability insurance for LLW disposal facilities with a lifetime aggregate limit of $\$ 25$ million for any one facility. Coverage offered is strictly limited to offsite damages.

One of the major limiting conditions on liability insurance for LLW disposal facilities is that states have little, if any, control over liability insurance coverage and availability. The recent ANI moratorium on providing any new LLW disposal facilities is a case in point. Even though ANI has traditionally shown a high level of cooperation with the nuclear industry, they control the level of scope and length of coverage, exclusions, and claims handling, and may only address a portion of the total needs of a LLW disposal facility.

Few, if any, insurance companies can be expected to enter the onsite or offsite insurance markets until conditions become much more stable. In fact, the environmental impairment insurance market might continue to deteriorate to where it would not be a useful financial assurance mechanism.

\subsection{Self-Insurance (Each Facility Alone)}

\subsubsection{Description}

An alternative to traditional insurance is self-insurance. Self-insurance is defined as a formal decision to develop a method for dealing with potential losses alone or in a group rather than transfer that responsibility. A self-insurance program is distinguished from noninsurance by establishing policies and procedures that provide for the payment of losses if they occur.

Sometimes self-insurance involves a combination of assuming and transferring risk. For example, many self-insurance programs are protected against events of unusual frequency or severity through the purchase of reinsurance. This transfers some aspects of the risk to specialized parts of the traditional insurance industry by paying a premium.

\subsubsection{Applicability}

Self-insurance is most appropriate when the following conditions exist:

- Insurance is too expensive compared to the transferred risk

- Insurance is unavailable

- Losses are frequent and small

- $\quad$ Losses are infrequent. 
Because insurance is not available for all the potential losses a disposal facility might encounter and there is no guarantee that currently available insurance will not be modified before the end of a facility's institutional control period, it is necessary to consider self-insurance as an alternative.

Self-insurance programs involve many characteristics of traditional insurance; the major difference is that self-insurance involves risk retention, rather than risk transfer. The self-insured would still contract as needed for several of the services that are provided by insurance companies, such as engineering, underwriting, actuarial support, claims handling, and reinsurance.

Self-insurance for each facility could be used to provide a source of funds that would be available to satisfy losses, should they occur. Prefunding may be selected, wherein funds are collected from waste generators through a mechanism such as a surcharge on disposed waste that is deposited in a fund and paid out if a loss occurs. Waste generators could pay a surcharge based on particular aspects of the waste disposed of at the facility. One basis for setting the cost of a surcharge might be the amount of radioactivity of the waste, representing the relative risk created by various generators. In this case, generators of highly radioactive LLW would pay a higher fee per cubic foot than those disposing of low-radioactive LLW. An alternative approach is to base charges simply on the volume of waste. Facilities currently disposing of LLW in the U.S. use a combination of waste volume and waste characteristics as a basis for determining waste disposal charges.

Alternatively, losses could be postfunded. This option would entail legally binding arrangements with generators to pay assessments if losses occur. In a postfunded plan, funds are not collected until the loss occurs. However, firm contractual arrangements must be made to ensure future funding, should the need develop.

A major reservation with postfunding potential financial losses is the prospect that not all generators that used the disposal facility would be available, capable, or even in existence when a loss might need funding. Many small generators (such as some industrial users of radioactive materials) might no longer exist or be able to provide their share of the required funds. However, other generators such as nuclear utilities, universities, hospitals, and government generators (or their successors) are much more likely to exist and be capable of providing the needed support. Because these generators are responsible for the majority of LLW volume and the vast majority of radioactive content, there is reasonable assurance that adequate financial support could be generated at a potential future time of need.

A combination of prefunding and postfunding could combine the advantages of each option. For example, it might be preferable to prefund to a level that would provide for losses with the highest probabilities of occurring. At the same time, enforceable postfunding provisions would be made to provide additional funds in case a loss were to occur that exceeded the prefunding limits. Such a combination would ensure that sufficient funds are in place for immediate use and ensure that additional funds would be available as needed. This could be one way of striking a balance between the often competing demands of financial efficiency and public and regulatory acceptability. 


\subsubsection{Availability}

Individual self-insurance is available for each facility because it is created by the insured, rather than purchased from an insurer.

\subsubsection{Rating/Premium Cost}

The premium cost for self-insuring each facility would be quite high in relation to the total risk. Generators should pay the full amount necessary to ensure adequate coverage for the reasonably foreseeable potential losses (burning layer losses). Protection against potential losses that are highly improbable but require coverage (excess layer losses) could be provided by generator guarantees to provide funds at the future time of need. However, due to the uncertainties inherent in projecting future events, generators might alternatively be required to pay an assessment to protect against both the burning and excess layers of losses. Later, they could receive a dividend if losses did not occur.

Prefunded self-insurance for each facility might be impractical for excess layer losses. It might be more reasonable for the burning layer losses or unnecessary if insurance can be purchased from an insurer.

\subsubsection{Limiting Conditions}

The need to protect against highly improbable, but potentially significant, financial losses may present a large economic burden on generators using a facility if prefunding is required. If postfunding is chosen, firm, legally enforceable commitments must be obtained from all generators to pay the needed assessments if financial losses occur. The ability of generators in existence at the time of the need to pay the assessments would remain a major uncertainty in considering the soundness of the plan.

\subsection{Self-Insurance (Insurance Pool)}

Self-insurance of each facility, described in Section 4.3, seems to be a logical solution to the lack of traditional insurance, except for the inherent lack of a statistically sound basis. This shortcoming can be overcome by sharing the risk through an insurance pool (many or all LLW disposal facilities together).

\subsubsection{Description}

Insurance pools are a variation of self-insurance involving several members. Insurance pools are much like traditional insurance companies but are developed for specific purposes, such as insuring one type of manufacturer or providing a special type of insurance. Many traditional insurance companies, such as the Factory Mutual Insurance Group, started this way and provide less expensive, broader coverage for members of the pool than is available through other means.

An insurance pool could take several forms:

- An unregulated insurance pool for host states and members of LLW compact regions that is sponsored by a central body, such as the Federal Government 
- A risk retention group owned by the disposal facilities

- A captive insurance company owned by the disposal facilities.

An insurance pool needs a sponsor that can develop the pool, lead its implementation, and provide for its continued operation. Typically, associations provide the impetus for establishing a pool and for providing the organizational support to continue the pool. In addition to such associations that may exist or be formed for LLW disposal facilities, the Federal Government might also sponsor the development and maintenance of such an insurance pool if appropriate authorizations were in place. Rather than being involved in risk financing or being responsible for providing funds to cover losses, the Federal Government might simply sponsor the organization and ensure continuation of the pool.

Risk retention groups are a legally different form of an insurance pool. They are formed as an insurance company in a state and are subject to regulation by the insurance commissioner of that state. The risk retention group has an advantage over pools in that it can offer an insurance policy that clients could use to demonstrate the existence of insurance. Because the financial assurance mechanism ultimately selected might behave quite differently from a typical insurance company, however, it might be preferable to avoid state regulation.

Captive insurance companies are somewhat like risk retention groups, except they are established in a jurisdiction that desires to attract such insurance activity (such as Vermont, Bermuda, and others). Such a captive insurance company can provide coverage for almost any type of potential loss and is only loosely regulated by the jurisdiction where it was established. Although a captive insurance company could be formed to provide insurance for LLW disposal facilities, there are no real advantages to using this form of organization, particularly where the operating costs of a captive insurance company can be much greater than those of a pool.

\subsubsection{Applicability}

An insurance pool would be able to provide the financial assurance necessary to fund potential onsite and offsite losses. Insurance pools, such as ANI, have been used by the nuclear power industry for insurance purposes. An insurance pool would have all of the same characteristics of a specialized insurance company, including engineering capabilities, underwriting facilities, actuarial services, claims handling services, and reinsurance.

The major difference between an insurance pool and traditional insurance companies would be the specialized nature of the pool, providing coverage only for LLW disposal facilities rather than insuring several different types of risk. If the potential exists for a significant loss, it might be difficult for an insurance pool to develop prefunded coverage that is adequate without being excessive in cost.

The insurance industry relies on spreading risk over several types of exposures to protect against variances in risk. The theory is that in any given year some types of risks will have higher than expected losses, while others will have lower than expected losses. A typical insurance company also relies on its capital and surplus to protect against unusually high losses. 
By their nature, insurance pools cannot spread risk over several types of exposures. They can, however, use reinsurance to help reduce the risk being born by the pool itself. Because of their size, insurance pools are usually limited in their ability to accumulate capital and surplus. For these reasons, pools would typically require a level of funding more conservative than that of traditional insurance companies to protect against excess demands on the fund.

Because most radioactivity (and volume of LLW) is produced by relatively stable institutions (e.g., utilities, hospitals, and universities), it may be possible to consider postfunding if it is impossible to obtain insurance for needed excess layers from the insurance industry (refer to Section 4.3.2). An insurance pool could apportion a loss requiring postfunding among its viable generators, as is currently done under the Comprehensive Environmental Response, Compensation, and Liability Act (CERCLA) cleanup projects.

\subsubsection{Availability and Limiting Conditions}

The availability and limiting conditions are interrelated in discussing the group self-insurance option. As stated in Section 4.3, self-insurance is created by the interested parties and is always available as an option. A pool is easier to create than risk retention groups and captive insurance companies, which must meet insurance regulatory criteria.

An important limiting condition is the challenge of obtaining agreement from all or several states or compact regions to participate in a pooled arrangement. In any group situation there are more competing interests to satisfy than if each individual state acts alone. The current LLW industry tends to be somewhat fragmented with some centralized or shared planning between states and compact regions. This points to the possibility of some central body, such as the Federal Government, that might sponsor and implement the pooled sharing of risks for many or all new LLW disposal facilities.

\subsubsection{Rating and Premium Cost}

The cost of pooled self-insurance would be similar to that of self-insurance for individual facilities. However, pooling eliminates inefficiencies inherent in a system of several independent but parallel self-insurance programs.

\subsection{Other Financial Assurance Mechanisms}

Sections 4.2 through 4.4 discuss the primary financial assurance mechanisms likely to be available or successful to meet the needs of LLW disposal facilities. However, when financial assurance mechanisms are necessary to protect against unlikely losses, some insured institutions in other industries use mechanisms other than insurance to provide necessary guarantees. The insurance industry can be expensive when protecting against low likelihood, high-loss-potential risks where there are several unknowns. Therefore, many companies choose instead to guarantee that they will pay for unlikely potential losses if they occur. Effectively, they are choosing to pay losses after they occur, rather than paying in advance to establish a contingency fund.

Two mechanisms are typically used for these purposes: surety bonds and financial guarantees. A surety bond is similar to an insurance policy in that an insurance company (called the "surety") 
guarantees to pay losses as defined in the surety bond. Unlike insurance policies, however, the surety has the right to recover these losses against the insured. A surety, in effect, is a guarantor of the financial ability of the insured to make good its promise to pay losses. Therefore, it is heavily dependent upon the financial ability of the insured and the surety company's ability to tap those resources to recover any claims that it might pay. Typically, surety bonds are used in performance contracts, contractor's projects, and similar situations.

A surety bond would be appropriate as a financial assurance mechanism if the surety companies could be convinced that the waste facility operator or waste generator would be financially sound at the time of a loss and that the funds necessary to settle the loss could be recovered. Because of the relatively long-term nature of risks associated with LLW disposal facilities, it is very doubtful that surety companies would have interest in this type of risk. In this investigation, no examples were found of similar uses of surety bonds by the waste disposal industry.

Financial guarantees are any form of promise, backed by a financial instrument, to pay for losses or lack of performance at some future time. It is up to the contractor to maintain the financial instruments and make them available for the intended purposes when needed. These less-structured mechanisms include having a contractor maintain earmarked cash funds, post a bank letter of credit, or pledge stocks or bonds to pay for losses if they occur. This differs from surety, which uses an independent guarantor with large resources of its own to back the guaranty.

Surety bonds and financial guarantees are unlikely solutions because of the relatively long-term nature of risks associated with LLW disposal facilities. Further, it would be very difficult to secure enough financial assurance to satisfy potentially significant losses, if protection is needed.

\subsection{Formulating a Financial Assurance Program}

Figure 2 summarizes the sequence of choices in formulating a financial assurance or risk management program for each type of potential loss. In formulating such a program, the following risk management options are available:

- $\quad$ Reduction

- Transfer

- Retention.

Risk reduction is any action that reduces the potential loss to the facility owner or operator. In practice, risk reduction amounts to risk avoidance. Such actions might focus on reducing the probability of an activity, the magnitude or severity of a potential loss, or both. Loss reduction at a LLW disposal facility can typically be accomplished by paying particular attention to such items as design, construction quality, and operating procedures.

Risk transfer includes all means of shifting the cost of a loss to someone else. The most common form of risk transfer is insurance, although risk can also be transferred by contract to other parties. The essential difference between risk reduction and risk transfer is that the probability or severity of the potential loss is reduced in the former, but not in the latter. 

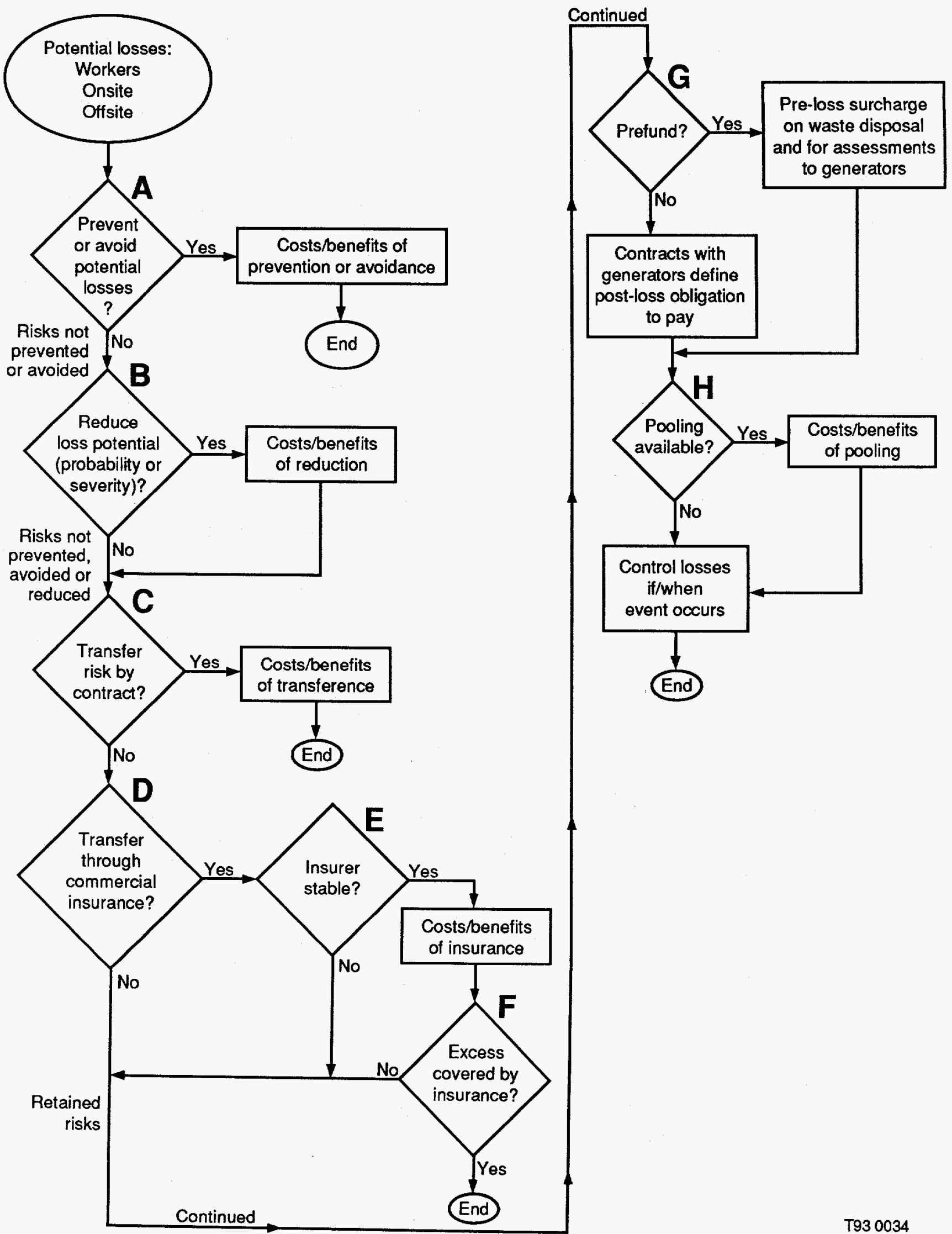

Figure 2. Flow chart of options and outcomes in formulating a financial assurance program. 
Risk retention results when risks are not eliminated or transferred. Those risks not eliminated using risk reduction or transfer techniques are retained.

As frequently mentioned in the discussion of Chapter 2, conditions may be recognized during the design, construction, operation, and maintenance of disposal facilities that might cause bodily or personal injury or property damage, or otherwise result in financial losses to the owner or operator. As this understanding develops, actions are assumed to be taken to reduce or eliminate the potential losses. There may be practical limits, however, on such actions.

After the risks of potential losses are eliminated or reduced to the extent judged reasonable or practical they must be either transferred or retained. Assuming there is a party willing to accept the risk, it might be transferred if any of the following statements are true:

- The risk is too large for the owner or operator to retain

- Transfer is mandated by law (e.g., WC insurance)

- The risk is more efficiently managed by transfer.

Risk transfer can occur by contract or through the purchase of insurance. As observed in earlier sections of this chapter, insurance is available only for potential offsite liabilities. Therefore, even though one or more of the three conditions listed above are satisfied, the opportunity for transfer may be so limited that it cannot occur or can only be partially transferred.

All risks that are not eliminated or transferred become a retained risk. Risks are retained either because there is no means of transfer, no planning has occurred, or an informed decision was made to do so. If planning is omitted, incomplete, or overlooked, potential losses might impose an unnecessary economic hardship on the facility owner or operator. The result might be the inability of a facility to perform as expected throughout its lifetime. Therefore, careful attention is needed to ensure that all potential losses are recognized and that appropriate preparations are made in case they occur.

For risks that are retained, decisions must be made as to whether they will be funded before (i.e., prefunded) or after (i.e., postfunded) a loss occurs. These possibilities are discussed in the sections that follow.

\subsubsection{Claims for Injury to Workers}

As a site owner reviews potential risks, worker injuries must not be overlooked. WC insurance is required by all state laws. Therefore, the site owner must meet the state requirements to provide proof of insurance or qualify as a self-insurer with the labor department in that state. This responsibility cannot be avoided or contractually transferred except to the extent that an employer can lease employees.

A decision to be insured or self-insured for WC insurance is based on the size of the potential cost (payroll and claims rate). There are a number of variations between fully self-insured and fully 
insured, which should be evaluated to determine their cost-effectiveness for a particular site owner. A facility with 50 employees, such as would be typical of LLW disposal facilities, might be forced by its small staff size to obtain traditional guaranteed cost insurance.

Standard WC insurance policies contain a section called Employer Liability. This section applies to claims not covered by the statutes. This is an important coverage because the courts have awarded compensation in recent years in excess of that provided by standard WC insurance policies. If standard limits are insufficient to meet the needs of the facility owner, higher limits should be requested.

Even though the facility might have no choice in how it funds worker injuries, it must still minimize losses through prevention and loss control activities. Loss control efforts are essential for all risks, regardless of the funding method selected.

The process of developing a financial assurance program for losses associated with injuries to facility workers is described in Figure 2 . While it might not be possible to prevent or avoid all potential losses (Decision A), it might be possible to reduce their probabilities and magnitudes (Decision B). Whatever potential losses remain after risk reduction that may not be transferred by contract (Decision C) must be transferred through insurance (Decision D) because of the requirements of state law.

WC limits might be exceeded under some conditions (Decision F). Therefore, some excess worker-related risk is retained by the facility owner or operator for which a decision must be made about the method of funding, i.e., prefunded vs. postfunded (Decision G).

To the extent that options exist to address worker-related potential losses, the costs and benefits of each decision can be evaluated. For example, tradeofls between further reductions in risk and the probability that the limits of WC insurance coverage will not be exceeded can be evaluated to determine the preferred risk management program.

\subsubsection{Onsite Losses}

As noted earlier, actions can be and are taken to reduce the risk of onsite losses by improvements in design, construction, operation procedures, and other areas. However, the entire risk of onsite losses can never be avoided.

Because insurance is not available, self-funding is the only available option. The decision to prefund or postfund the loss must consider the financial implications each choice would have for the site operators, potential cost to generators, and political and institutional acceptability. Because of public and regulatory concern about the financial stability of LLW disposal facilities, postfunding might not be acceptable for some types of losses.

If prefunding is chosen, a facility operator might not be able to pay a significant loss in the early operational years because it would not have had enough time to accumulate adequate funds. Funding should be sufficient at a later date to prefund most if not all of the more likely losses. 
The creation of a shared funding mechanism for excess losses would be an economically efficient use of capital. However, because of the relatively fragmented nature of the LLW disposal industry, risk sharing options might not be available without the leadership of some central body, such as the Federal Government.

Figure 2 also describes the process of developing a financial assurance program for potential onsite losses. Some potential losses might be completely avoided (Decision A) and others might be minimized (Decision B). As previously discussed, most onsite risks cannot be transferred (Decisions C and D) and, therefore, must be retained. Funding these retained risks may be provided either before or after a loss (Decision G). Pooling (Decision H), however, might be difficult to accomplish.

If an activity occurs that produces losses, efforts should be made to limit or contain the extent of damage that results, as shown at the conclusion of the flowchart in Figure 2.

As with worker-related risks, there are numerous choices available in formulating a financial assurance program for onsite losses. The cost and benefits of these choices to the owner or operator, generators, public health, environment, and state should be considered. For example, it might be preferable, though possibly more costly, to expend extra effort to reduce a risk rather than retain it.

\subsubsection{Claims for Injury or Property Damage by Offsite Parties}

Some of the risks to offsite parties can be avoided. Limiting site access to workers only, for example, might help avoid onsite injuries to nonworkers and damage to offsite property while it is at the facility.

Although not substantiated by the historical record to date, it is assumed that liabilities might arise from an accidental or unexpected discharge into the surrounding air or water. Methods for reducing the probability and potential severity of such discharges might include creating backup systems for all parts of the process that might exceed approved operating limits.

It is possible that waste generators using the facility will fund any offsite losses if they occur. Still, it is the responsibility of the facility owner or operator to determine whether to obtain insurance or to self-fund potential losses. At this time, a limited amount of coverage is available, up to $\$ 25$ million through ANI. In the early years, it makes sense to purchase this insurance. If insurance is unreasonably priced or provides inadequate coverage, efforts should be made to establish a selfinsurance fund with the intent of phasing out the purchased coverage. Whether insurance or selfinsurance is provided, the adequacy of the $\$ 25$ million limit should be examined in relation to the needs of the facility.

Facilities could work together to create an excess liability pool. Although it could only offer a limited amount of insurance in the early years, it could become an extremely cost-effective method of sharing risk. 
Insurer insolvencies have skyrocketed in the last few years. As a result, Congress is considering federal regulation of insurers. (Reference 9). The Dingell Report to Congress ${ }^{a}$ cites major problems in the U.S. insurance industry. These concerns need to be considered by the facility owner when purchasing insurance from a traditional insurer or alternative insurer such as a captive or risk retention group. There are several reliable industry sources that evaluate or rate the potential for insurer solvency. In addition, acceptable values of standard financial ratios are published for both captive and traditional insurers (i.e., premium to surplus ratio).

In searching for adequate and appropriate coverage, a facility owner should explore the current position of the Underwriters at Lloyd's of London. Their Nuclear Syndicate has over 1,000 members, although it was only recently established. ${ }^{b}$ This syndicate is continuing to expand its opportunities and might provide coverage to LLW facilities beyond that currently being provided by ANI.

Nuclear decontamination and premature decommissioning coverages are offered to the utility industry by Nuclear Mutual Ltd. (established 1973) and by the Nuclear Electric Insurance Ltd. (established 1980). ${ }^{c}$ Where these captive insurers were created by the utility industry to meet their specific needs, they eventually might offer some kind of insurance coverage in the LLW disposal marketplace.

The flowchart in Figure 2 describes the options available in preparing a risk management program for offsite losses. Some, but not all, potential losses can be prevented or avoided (Decision A). Those not prevented or avoided might be reduced (Decision B). Some risks not prevented, avoided, or reduced may be transferred by contract (Decision C) or by insurance (Decision D). The stability of offsite liability insurance must be considered (Decision E) and preparations must be made for the possibility of losses in excess of coverage offered by insurance (Decision F).

All retained risks must be prefunded or postfunded (Decision G). Pooling for coverage of retained offsite risks (Decision $H$ ) is possible. In the event that offsite losses occur, efforts to contain or limit the extent of the losses should be pursued, as depicted at the conclusion of the flowchart.

a. "Failed Promises: Insurance Company Insolvencies," a report by the Subcommittee on Oversight and Investigations of the Committee on Energy and Commerce, U.S. House of Representatives, February 1990.

b. "A New View From Lloyd's," an address by Michael G. Dawson, Underwriter, The Nuclear Syndicate, Lloyd's of London, to the Nuclear Insurance Conference, January 15, 1991.

c. Presentation by Robert Frownfelker, Director of Corporate Insurance, Consumers Power Co., at the USLEA Nuclear Insurance '91 Conference, 1991. 


\section{REFERENCES}

1. "Atomic Energy Act of 1954," PL 83-703, August 1954.

2. Federal Register, 47 FR 248, "Licensing Requirements for Land Disposal of Radioactive Waste (10 CFR Part 61)," U.S. Nuclear Regulatory Commission, December 27, 1982, pp. 57463-57477.

3. "Low-Level Radioactive Waste Policy Act," PL 96-573, December 1980.

4. "Low-Level Radioactive Waste Policy Amendments Act," PL 99-240, January 1985.

5. New York State, Final Generic Environmental Impact Statement for Promulgation of 6 NYCRR, Subpart 383-6, Financial Assurance Requirements for Low-Level Radioactive Waste Disposal Facilities (two volumes), New York State Department of Environmental Conservation, Division of Hazardous Substances Regulation, Bureau of Radiation, September 1991.

6. Environmental Protection Agency, Background Document-Final Rule: Closure, Post-Closure Care, and Financial Responsibilities Requirements-Hazardous Waste Treatment, Storage, and Disposal Facilities, EPA Office of Solid Waste, EPA/530-SW-86-009, April 1986.

7. "Financial Assurance Workshop Proceedings," Northeast Interstate Low-Level Radioactive Waste Commission, July 1989.

8. "Financial Responsibility for Liability and Cleanup for Radioactive Materials Licensees and Low-Level Radioactive Waste Permittees," submitted by the State of Washington, Department of Ecology, Low-Level Radioactive Waste Program, to the 50th Legislature, December 1987.

9. U.S. Department of Energy, Prototype License Application: Safety Analysis Report, Belowground Vault, Low-Level Waste Management Program, DOE/LLW-72T, Volumes I and II, October 1988.

10. "The Sky May Not Fall In, But ..." Business Week, January 14, 1991. 
Appendix A

Sample Application of Approaches to Developing a Financial Assurance Program 



\section{Appendix A}

\section{Sample Application of Approaches to Developing a Financial Assurance Program}

The sole purpose of this appendix is to provide an example of how the approaches described in Chapters 2, 3, and 4 of this document might be applied. This discussion is for illustrative purposes only, realizing that development of values for an actual financial assurance plan would require greater rigor in detail, documentation, and completeness.

All values reported or estimated here are based on characteristics of the hypothetical low-level radioactive waste (LLW) disposal facility described in Appendix B and Reference A-1. Although no attempt should be made to relate the values presented in this appendix to any actual or potential $L L W$ disposal facility, the approaches described and illustrated by this document can provide some insight on approaches that could be used to identify, quantify, and manage potential financial liabilities at $L L W$ disposal facilities.

This appendix quantifies three types of potential loss scenarios (unusual operating conditions, premature vault failure, and extreme natural occurrences). These three scenarios were designed and evaluated to illustrate how a financial assurance plan might be structured using mechanisms designed to address potential onsite, worker, and offsite liabilities.

It should be made clear that even though these three types of liabilities are evaluated separately in this example, they could appear in combination (as shown by Table 1 of the main text) following a loss-producing activity.

\section{A-1. WORKER CLAIMS-UNUSUAL OPERATING CONDITIONS}

This evaluation of potential losses due to worker claims caused by unusual operating conditions is based on conventional industrial accident frequency data. It is hypothesized that a worker might be involved in an accident at a disposal facility and later develop cancer, whereupon the worker claims that the cancer is a result of the accident at the disposal facility. Although this claim would rightly be covered by Workers' Compensation insurance, it is assumed that successful claims are made against the facility. The cost of the claim, including the cost of its defense, is based on insurance statistics for industrial liability.

Table A-1 shows the potential costs of claims related to unusual operating conditions. These claims are for all cancers that occur among facility workers involved in an industrial accident without regard to their actual causes. As shown in Table A-1, Column (3), it is assumed that over the life of the facility, two or three workers might receive awards for cancer beyond compensation provided by Workers' Compensation insurance. It is assumed that the average cost per award would be about $\$ 375,000$, including the costs of defense and claims handling. The potential cost per occurrence would 
depend upon the number of workers who are injured, develop cancer, and bring successful damage claims. The total probable cost for this example is calculated to be approximately $\$ 1,015,000$.

Table A-1. Unusual operating conditions-summary of estimated potential cost.

\begin{tabular}{|c|c|c|c|c|c|c|c|}
\hline & $\begin{array}{l}\text { Col } \\
\text { (1) }\end{array}$ & $\begin{array}{l}\text { Col } \\
\text { (2) }\end{array}$ & $\begin{array}{l}\text { Col } \\
\text { (3) }\end{array}$ & $\begin{array}{l}\text { Col } \\
\text { (4) }\end{array}$ & $\begin{array}{l}\text { Col } \\
\text { (5) }\end{array}$ & $\begin{array}{l}\text { Col } \\
(6)\end{array}$ & $\begin{array}{l}\text { Col } \\
\text { (7) }\end{array}$ \\
\hline $\begin{array}{c}\text { Period } \\
\text { (years after } \\
\text { operations begin) }\end{array}$ & Workers & $\begin{array}{c}\text { Annual } \\
\text { accident } \\
\text { frequency } \\
\text { rate per } \\
\text { worker }\end{array}$ & $\begin{array}{l}\text { Potential } \\
\text { damage } \\
\text { claims }\end{array}$ & $\begin{array}{l}\text { Average } \\
\text { cost per } \\
\text { claim } \\
(\$ 000)\end{array}$ & $\begin{array}{c}\text { Total } \\
\text { probable } \\
\text { cost } \\
(\$ 000)\end{array}$ & $\begin{array}{l}\text { Present } \\
\text { value } \\
\text { factor }\end{array}$ & $\begin{array}{c}\text { Present } \\
\text { value of } \\
\text { potential } \\
\text { cost } \\
(\$ 000)\end{array}$ \\
\hline $0-5$ & 50 & $3.383 \%$ & 0.6 & 375 & 225 & 0.649 & 146 \\
\hline $6-30$ & 50 & $1.759 \%$ & 1.5 & 375 & 563 & 0.448 & 252 \\
\hline $31-32$ & 20 & $3.231 \%$ & 0.1 & 375 & 38 & 0.321 & 12 \\
\hline $33-35$ & 15 & $3.231 \%$ & 0.1 & 375 & 38 & 0.302 & 11 \\
\hline $36-45$ & 10 & $0.954 \%$ & 0.1 & 375 & 38 & 0.257 & 10 \\
\hline $46-60$ & 7 & $0.954 \%$ & 0.1 & 375 & 38 & 0.189 & 7 \\
\hline $61-135$ & 5 & $0.954 \%$ & 0.2 & 375 & 75 & 0.062 & 5 \\
\hline Total $^{\mathbf{a}}$ & & & 2.7 & & 1,015 & & 443 \\
\hline
\end{tabular}

Notes

Col (1) See Appendix B, Table B-5.

Col (2) See Table A-2.

Col (3) Col (1) $\times$ Col (2) $\times$ number of years in period $\times 1 / 3 \times 0.8 \times 0.25$. Assumes $1 / 3$ of all injured workers will contract cancer during their lifetimes, $80 \%$ of workers with cancer will file suit, and $25 \%$ of the suits result in losses.

Col (4) $\$ 300,000 \times 1.25$. Assumes the average award will be $\$ 300,000$ and the costs of defending the suit and claims handling will be an additional $25 \%$.

$\mathrm{Col}(5) \mathrm{Col}(3) \times \mathrm{Col}(4)$

Col (6) 1.025 -(mid-year of the period +15 years). Assumes a discount rate of $2.5 \%$ per year and a cancer latency period of 15 years.

$\mathrm{Col}(7) \mathrm{Col}(5) \times \mathrm{Col}(6)$.

a. Total may not equal the sum of all components due to rounding. 


\section{A-1.1 Details of Calculations}

Table A-2 shows accident frequencies by type of accident for several industry groups. For each type of accident, a range of accident frequencies is shown corresponding to the frequencies for the most and least hazardous industries in that category. Based on these frequencies, accident rates were selected for the three major phases of facility operation: construction and initial operation (0-5 years), normal operation (6-30 years), closure (31-35 years), and long-term monitoring ( $36-135$ years).

The total selected accident frequencies from Columns (5) through (8) of Table A-2 are copied onto Column (2) of Table A-1. The other columns in Table A-1 are calculated as described in the notes. 
Table A-2. Operational accidents $\rightarrow$ selection of accident frequencies.

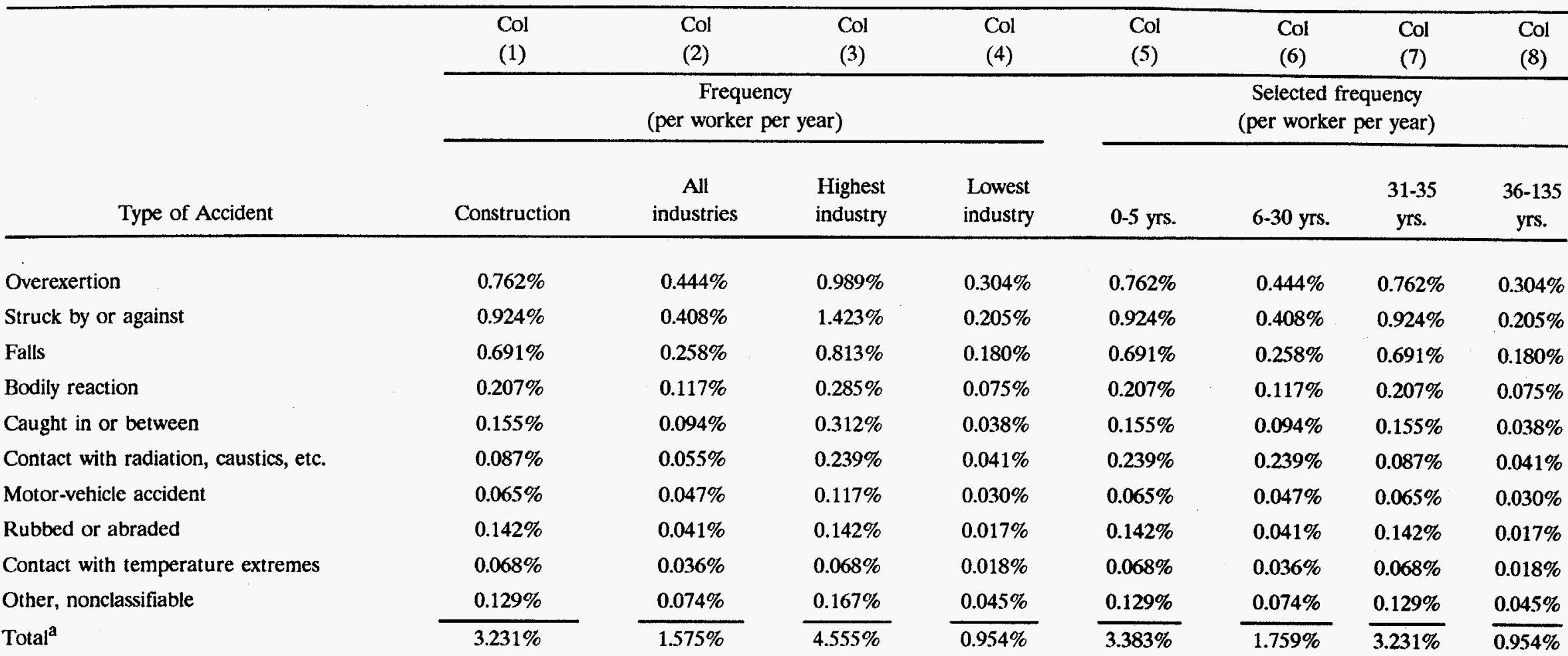

$\underline{\text { Notes }}$

Cols(1)-(4) From the National Safety Council's "Accident Facts," 1989 Ed., pp. 32-33.

Col (5) "Construction" accident frequencies were selected for the first 5 years of the site operations period except for the "contact with radiation, caustics, etc." hazard. For this type of accident, the highest industry frequency rate was used.

$\mathrm{Col}$ (6) "All industries" accident frequencies were selected for the last 25 years of the site operations period except for the "contact with radiation, caustics, etc." hazard. For this type of accident, the highest industry frequency rate was used.

Col (7) "Construction" accident frequencies were selected for the site closure period.

Col (8) "Lowest industry" accident frequencies were selected for the site institutional control period. 


\section{A-2. ONSITE LOSSES-PREMATURE VAULT FAILURE}

The probabilities of a vault failure at various times after facility closure have been estimated using a Monte Carlo probability simulation as described in Appendix $C$. In the event of a vault failure, three remedial action scenarios were evaluated to determine potential onsite losses. These actions range from repairing the vault (least expensive) to relocating all waste from one vault to another (most expensive).

\section{A-2.1 Probability and Cost of Vault Failure}

The probability of vault failure is shown in Table A-3, Columns (1) and (2). Note that no failures are predicted until 20 years after the operational period of the facility (year 50 ). Also, vault failures after year 135 are not considered. The details and methodology of the vault failure analysis are contained in Appendix C. Table A-4 shows the potential cost of vault failure. Following vault failure, four basic remedial actions are possible. For purposes of this report, only the first three were evaluated.

1. Vault repair

2. Vault repair and treatment of contaminated groundwater

3. Relocation of waste from one vault

4. Relocation of all waste.

Engineering estimates of the costs associated with each of the first three possible actions range from $\$ 600,000$ for vault repair to $\$ 10$ million for relocation of all the waste from one vault to another. The remedial action actually taken will depend on a number of factors including the extent of structural damage, how soon the failure was detected, and public reaction. In Table A-4, Columns (2) and (3) show selected probabilities for the three remedial actions. Based on these probabilities, the average potential costs per failure for Class $\mathrm{A}$ and for Class $\mathrm{B} / \mathrm{C}$ vaults are estimated to be $\$ 1,360,000$ and $\$ 2,490,000$, respectively.

As shown in Table A-3, the chance of failure for a Class A vault is about $8 \%$ and about $4 \%$ chance for the Class B/C vault during the first 135 years of the facility's life. In the event of failure, it was assumed that contamination would be released from the disposal vault, although the natural characteristics of the site are expected to keep it well within the boundaries of the facility. The vault would be repaired or otherwise remediated. When the various remedial alternatives are combined with their respective probabilities, the total probable cost is estimated to be about $\$ 208,000$. 
Table A-3. Premature vault failure-summary of estimated cost.

\begin{tabular}{|c|c|c|c|c|c|c|}
\hline \multirow[b]{3}{*}{$\begin{array}{c}\text { Period } \\
\text { (years after } \\
\text { operations begin) }\end{array}$} & $\begin{array}{l}\text { Col } \\
(1)\end{array}$ & $\begin{array}{l}\text { Col } \\
(2)\end{array}$ & $\begin{array}{l}\text { Col } \\
(3)\end{array}$ & $\begin{array}{l}\text { Col } \\
(4)\end{array}$ & $\begin{array}{l}\text { Col } \\
(5)\end{array}$ & $\begin{array}{l}\text { Col } \\
(6)\end{array}$ \\
\hline & \multicolumn{2}{|c|}{$\begin{array}{l}\text { Vault failures within period; } \\
\text { incremental probability (\%) }\end{array}$} & \multicolumn{2}{|c|}{$\begin{array}{l}\text { Total probable cost } \\
(\$ 000)\end{array}$} & \multirow[b]{2}{*}{$\begin{array}{l}\text { Present } \\
\text { value } \\
\text { factor }\end{array}$} & \multirow{2}{*}{$\begin{array}{l}\text { Present value } \\
\text { of potential } \\
\text { cost } \\
(\$ 000)\end{array}$} \\
\hline & $\begin{array}{l}\text { Class A } \\
\text { waste }\end{array}$ & $\begin{array}{l}\text { Class } B / C \\
\text { waste }\end{array}$ & $\begin{array}{l}\text { Class A } \\
\text { waste }\end{array}$ & $\begin{array}{l}\text { Class } B / C \\
\text { waste }\end{array}$ & & \\
\hline $0-30$ & 0.0 & 0.0 & 0 & 0 & 0.691 & 0 \\
\hline $31 \cdot 50$ & 0.0 & 0.0 & 0 & 0 & 0.372 & 0 \\
\hline $51-70$ & 0.6 & 0.4 & 8 & 10 & 0.227 & 4 \\
\hline $71-90$ & 0.8 & 0.6 & 11 & 15 & 0.139 & 4 \\
\hline $91-110$ & 1.8 & 0.4 & 24 & 10 & 0.085 & 3 \\
\hline $111-135$ & 5.0 & 2.5 & 68 & 62 & 0.049 & 6 \\
\hline Total $^{a}$ & 8.2 & 3.9 & 111 & 97 & & 17 \\
\hline
\end{tabular}

$\underline{\text { Notes }}$

$\overline{\mathrm{Col}}(1)$ and (2) Based on a Monte Carlo computer simulation using the BARRIER model of concrete degradation.

Col (3) Col (1) $\times \$ 1,360,000$. $\$ 1,360,000$ taken from Table A-4, Col (4).

Col (4) Col (2) $\times \$ 2,490,000$. $\$ 2,490,000$ taken from Table A-4, Col (5).

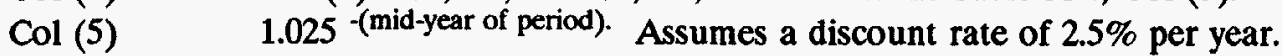

Col (6) $\quad[\mathrm{Col}(3)+\mathrm{Col}(4)] \times \mathrm{Col}(5)$.

a. Total may not equal sum of components due to rounding. 
Table A-4. Premature vault failure-potential cost per failure.

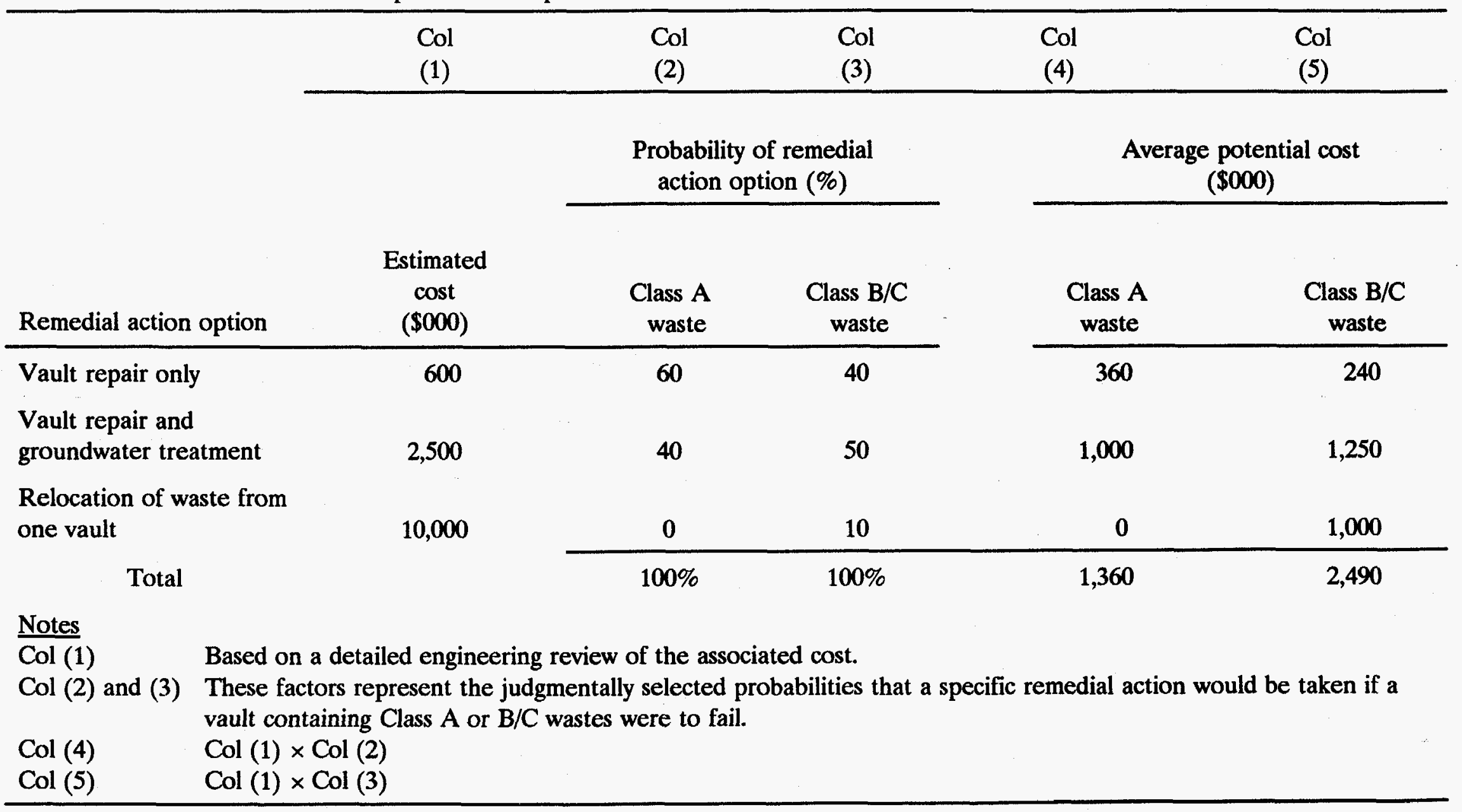




\section{A-3. OFFSITE LOSSES-EXTREME NATURAL OCCURRENCES}

In this report, extreme natural occurrences include severe windstorms or floods. Based upon an engineering evaluation of the hypothetical facility described in Appendix B, which included major design and operational procedures, disposal vault size, construction, closure, and how waste would be off-loaded and placed in the vaults, it was concluded that, for purposes of this report, a major earthquake or fire would not produce offsite contamination. This report does assume that offsite contamination would be caused by a severe windstorm or flood during the operational period of the facility. It also assumes that such an occurrence would cause neighboring residents to demand compensation for health effects (defined as cancers), periodic health monitoring, cleanup of contaminated areas, and decreased property values as shown on Table A-5.

The potential cost per occurrence is calculated to be approximately $\$ 44,744,000$, as indicated on Table A-5. Table A-6 shows that once the probability of an extreme natural occurrence is factored in, the probable cost due to extreme natural occurrences during the lifetime of the facility is about $\$ 1,343,000$. The following is a discussion of the assumptions and methods used to develop these figures.

\section{A-3.1 Probability of Occurrence}

The average expected annual probability of a severe windstorm or flood has been estimated to be $0.1 \%$, based on International Standards Organization (ISO) data for "extended coverage" insurance. The details of this calculation are shown in Tables A-7 and A-8.

\section{A-3.2 Cost Per Occurrence}

It is assumed that during operations a severe windstorm might spread contamination beyond the facility boundary within the most populous 45 -degree sector up to a distance of 4 kilometers. For consistency, it is assumed that a flood might also spread contamination beyond the facility boundary over an area equal to that of the windstorm and potentially expose the same number of persons.

Based on actuarial data for medical claims, it is assumed that one-third of those potentially exposed in the contaminated area (see Table A-9) would develop cancer during their lifetime and $80 \%$ of them would file suit claiming the cancer was caused by the occurrence. Of those filing suit, it is assumed that $25 \%$ receive compensation averaging $\$ 300,000$. The cost of defending these suits and handling the claims is assumed to add $25 \%$ to the average amount received. After discounting the costs of cancer claims by $2.5 \%$ per year for an assumed latency period of 15 years, the total potential cost of health effects per occurrence is estimated to be about $\$ 5,541,000$, as indicated on Table A-5.

A second potential cost following an extreme natural occurrence is health monitoring. These costs assume that all exposed persons in the contaminated area would receive annual health checkups for 25 years at $\$ 200$ each. This yields a total potential cost of approximately $\$ 1,605,000$ per occurrence, as shown on Table A-5. 
A third potential cost following an extreme natural occurrence is cleanup of the contaminated area. As shown on Table A-5, it is estimated that the cleanup costs per windstorm or flood would be about $\$ 15,700,000$. This cost is based on the assumptions that:

1. The average cost of removing and disposing of the contaminated matter from the surface of the earth is $\$ 2.50$ per square meter.

2. The surface area to be cleaned is contained within a 45-degree sector having a radius of 4 kilometers. The area of this surface equals approximately $6,280,000$ square meters.

The cleanup cost would be calculated as $\$ 2.50 \times 6,280,000$, or $\$ 15,700,000$.

A fourth cost resulting from an extreme natural occurrence is the devaluation of residential property near the facility. This cost is estimated to be about $\$ 21,928,000$. Tables A-9 and A-10 show the details underlying the calculation of this cost over the years of facility operation. The calculations are based on the following assumptions:

- The average number of people per household is 2.75 .

- The average value of each devalued property is $\$ 150,000$.

- The degree of devaluation is a function of the distance from the facility. For consistency, the degree of devaluation at each distance from the disposal facility is assumed to be the same as the probability of exposure used on Table A-9 for determining the potentially exposed population. 
Table A-5. Extreme natural occurrences-potential cost per occurrence.

\begin{tabular}{llllll} 
Col & Col & Col & Col & Col & Col \\
$(1)$ & $(2)$ & $(3)$ & $(4)$ & $(5)$ & $(6)$ \\
\hline
\end{tabular}

Potential cost per occurrence

Windstorm, flood

\begin{tabular}{cccccc}
$\begin{array}{c}\text { Exposed } \\
\text { population }\end{array}$ & $\begin{array}{c}\text { Health } \\
\text { effects } \\
(\$ 000)\end{array}$ & $\begin{array}{c}\text { Medical } \\
\text { monitoring } \\
(\$ 000)\end{array}$ & $\begin{array}{c}\text { Cleanup } \\
(\$ 000)\end{array}$ & $\begin{array}{c}\text { Property } \\
\text { devaluations } \\
(\$ 000)\end{array}$ & $\begin{array}{c}\text { Total }^{\mathrm{a}} \\
(\$ 000)\end{array}$ \\
\hline 321 & 5,541 & 1,605 & 15,700 & 21,928 & 44,744
\end{tabular}

$\stackrel{P}{\stackrel{2}{N}}$

\section{$\underline{\text { Notes }}$}

Col (1) See Table A-9, Col (4).

Col (2) Col (1) $\times 1 / 3 \times 0.8 \times 0.25 \times \$ 300,000 \times 1.25 \times 1.025^{-15}$. Assumes $1 / 3$ of those exposed to contamination will contract cancer during their lifetime, $80 \%$ of those with cancer will file suit, $25 \%$ of the suits result in losses, each successful suit will cost an average of $\$ 300,000$, defending the suits and handling claims will be an additional $25 \%$ to the average cost of each successful claim, a discount rate of $2.5 \%$ per year, and a cancer latency period of 15 years.

$\mathrm{Col}(3) \quad \mathrm{Col}(1) \times \$ 200 \times 25$. Assumes yearly medical monitoring costing $\$ 200$ each for 25 years.

$\mathrm{Col}(4) \quad \$ 2.50 \times 6,280,000$. Assumes an average cleanup cost of $\$ 2.50$ per square meter and contamination of a $6,280,000$-square-meter area.

Col (5) See Table A-10, Col (5).

$\mathrm{Col}(6) \quad \mathrm{Col}(2)+\mathrm{Col}(3)+\mathrm{Col}(4)+\mathrm{Col}(5)$.

a. Total may not equal sum of components due to rounding. 
Table A-6. Extreme natural occurrences $\rightarrow$ summary of estimated cost.

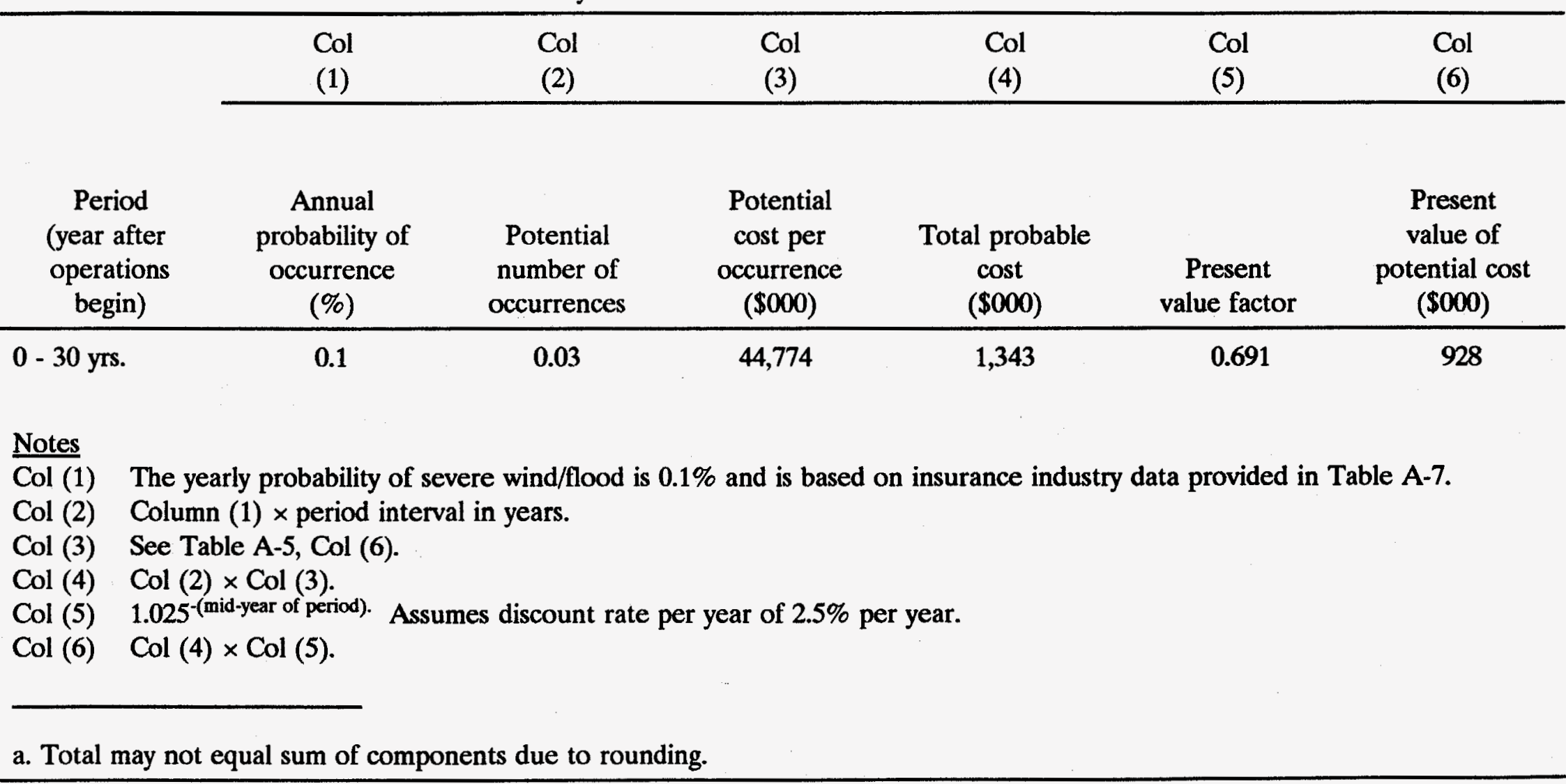


Table A-7. Extreme natural occurrences-severe windstorm/flood probabilities.

Amounts of insurance $\$ 500,001-\$ 1,000,000$

(1) Selected rate per $\$ 100$ of value

(2) Estimated average amount within band

(3) Average premium (1) $\times(2) / 100$

(4) Loss and loss adjustment (\% of premium)

(5) Estimated average claim size

(6) Wind/flood frequency per year $(3) \times(4) /(5)$

(7) Portion of wind/flood which are "major"

(8) Major wind/flood probability (6) $\times(7)$

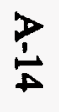

(9) Selected major wind/flood probability
High

0.150

$\$ 750,000$

$\$ 1,125$

$55.0 \%$

$\$ 30,000$

$2.06 \%$

$1.38 \%$

$5.0 \%$

$0.10 \%$

$0.10 \%$

Note

Row (1) Selected after a review of published extended coverage rates for a number of types of operations (a selection of which are shown in Table A-8).

Row (4) Based on the "permissible loss ratio" built into Insurance Services Office rates.

Row (5) Selected based on the average claim sizes for $\$ 500,000-1,000,000$ of insurance.

Row (7) Judgmentally selected. 


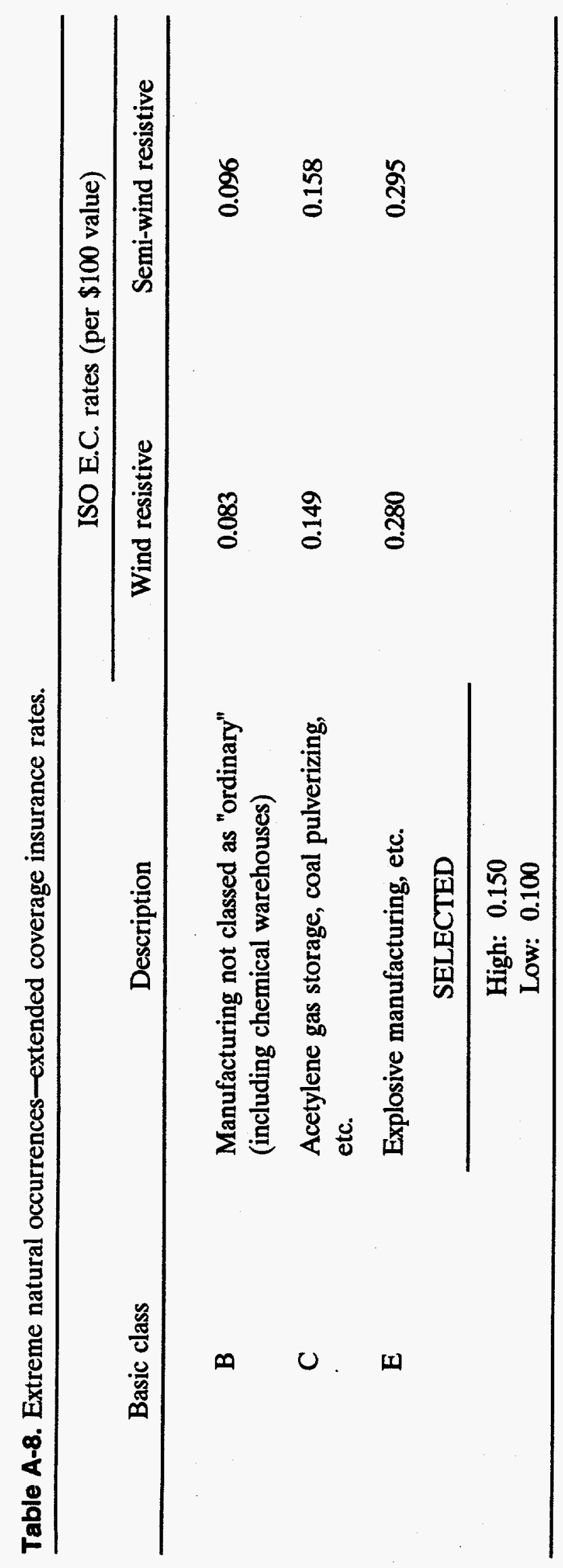


Table A-9. Extreme natural occurrences-potential population exposure per occurrence.

\begin{tabular}{lllll}
\hline Col & Col & Col & Col \\
$(1)$ & $(2)$ & $(3)$ & $(4)$ \\
\hline
\end{tabular}

\begin{tabular}{lcccc} 
& $\begin{array}{c}\text { Radius } \\
\text { around } \\
\text { facility } \\
(\mathrm{km})\end{array}$ & $\begin{array}{c}\text { Incremental } \\
\text { population }\end{array}$ & $\begin{array}{c}\text { Probability } \\
\text { of } \\
\text { exposure }\end{array}$ & $\begin{array}{c}\text { Potentially } \\
\text { exposed } \\
\text { population }\end{array}$ \\
\hline Severe windstorm/flood & 1 & 0 & $100 \%$ & 0 \\
& 2 & 3 & $85 \%$ & 3 \\
& 3 & 51 & $65 \%$ & 33 \\
& 4 & 1,140 & $25 \%$ & 285 \\
Total $^{\mathrm{b}}$ & 5 & 3,705 & $0 \%$ & 0
\end{tabular}

\section{Notes}

Col (2) See Section B.2.2, Appendix B. Based on the most populous $45^{\circ}$ sector up to a distance of 4 kilometers of the reference facility.

Col (3) These figures represent the judgmentally selected probability of measurable radioactive contamination given an extreme natural occurrence.

$\mathrm{Col}(4) \quad \mathrm{Col}(2) \times \mathrm{Col}(3)$.

a. Based upon an engineering evaluation of the hypothetical facility described in Appendix B, it is assumed that a major earthquake is not expected to produce offsite contamination.

b. Total may not equal sum of components due to rounding. 
Table A-10. Extreme natural occurrences-potential property devaluation, cost per occurrence.

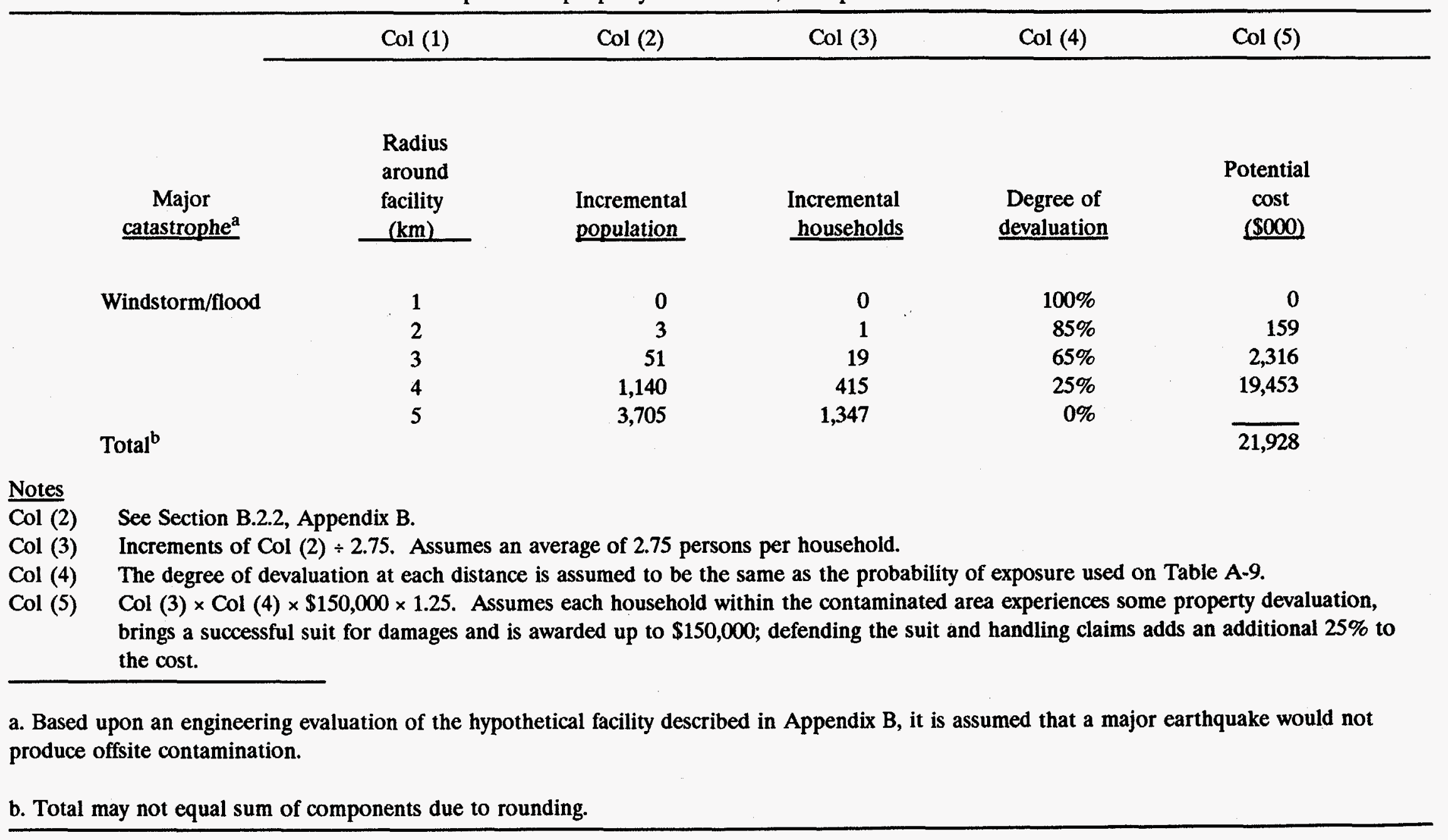




\section{A-4. SUMMARY OF SAMPLE APPLICATION}

Table A-11 shows that the potential cost per occurrence of the financial loss scenarios evaluated in this appendix might be as high as $\$ 44.7$ million if a severe windstorm or flood were to occur. However, when the present value of the potential costs are determined, the values become much smaller. For instance, the present value of the example noted above is about $\$ 0.9$ million. The present value figure is significantly smaller because it takes into account both the probability of the occurrence actually happening and how far in the future it is likely to occur. The present value for all activities evaluated in this appendix is approximately $\$ 1.4$ million.

Table A-11. Financial summary-estimated potential costs. ${ }^{a}$

\begin{tabular}{|c|c|c|c|}
\hline Financial loss scenario & $\begin{array}{l}\text { Potential } \\
\text { cost per } \\
\text { occurrence } \\
(\$ 000)\end{array}$ & $\begin{array}{l}\text { Total } \\
\text { probable } \\
\text { cost } \\
(\$ 000)\end{array}$ & $\begin{array}{l}\text { Present } \\
\text { value of } \\
\text { potential } \\
\text { cost }(\$ 000)\end{array}$ \\
\hline $\begin{array}{l}\text { Worker claims-unusual operating } \\
\text { conditions }\end{array}$ & $375^{\mathrm{b}}$ & $\$ 1,015$ & $\$ 443$ \\
\hline Onsite losses-premature vault failure & 3,850 & 208 & 17 \\
\hline $\begin{array}{l}\text { Offsite losses-extreme natural } \\
\text { occurrences }\end{array}$ & 44,744 & $\underline{1,343}$ & $\underline{928}$ \\
\hline Total $^{\mathrm{c}}$ & & 2,566 & 1,388 \\
\hline \multirow{2}{*}{\multicolumn{4}{|c|}{$\begin{array}{l}\text { a. Because of the hypothetical nature of this facility and the site at which it is located, caution } \\
\text { and judgment must be exercised in using the results presented in this table. } \\
\text { b. Potential cost per successful claim. The potential cost per occurrence would depend upon } \\
\text { how many workers are injured, develop cancer, and bring successful damage claims. }\end{array}$}} \\
\hline & & & \\
\hline \multicolumn{4}{|c|}{ c. Total may not equal the sum of individual components because of roundoff error. } \\
\hline
\end{tabular}




\section{A-5. DEVELOPMENT OF A FINANCIAL ASSURANCE PLAN}

A plan for providing the needed financial assurance for the hypothetical facility (Appendix B) is described in this section. These results are presented to illustrate the application of the approaches presented in Chapters 2 through 4 of the main body of the report. No generalization of specific volumes presented in these results or conclusions can be made to either existing or potential $L L W$ disposal facilities.

\section{A-5.1 Discussion}

Any financial assurance plan must begin with quantitative data such as that provided in Sections A.1-5. In addition, policy decisions must be made as to what the financial assurance plan is intended to accomplish. For example, a financial assurance plan that is to provide resources for all potential losses-regardless of how likely the individual losses might be-would be structured very differently than one designed to cover the present value of losses having the greatest probability of happening. Such decisions would be based on several factors including State regulations, available financial assurance mechanisms, resources of LLW generators, and the preferences of bodies influencing the facility development process (e.g., citizen advisory groups, siting commissions, and oversight committees).

The financial assurance plan described in this appendix is intended to provide coverage for the greatest, nondiscounted potential loss that might occur for each of the three categories of losses (worker-, onsite-, and offsite-related damages). It is assumed that the characterization of the three scenarios evaluated in this appendix is sufficient for purposes of this example.

It should be noted that, following facility closure, the potential for offsite liability claims decreases significantly. This is primarily due to three factors:

1. The disposal structures containing the waste are closed in a manner that incorporates barriers specifically designed to protect against intrusion by both man and nature.

2. The disposal area is surrounded by a buffer zone that utilizes the natural characteristics of the area to contain the waste onsite.

3. The amount of radioactivity at the disposal facility constantly deceases over time in accordance with the natural law of radioactive decay.

\section{A-5.2 Structure}

A combination of currently available insurance, self-insurance, and an industry insurance pool has been used to form the basic structure of a financial assurance plan for the potential losses shown on Table A-11. This structure provides a sequence of coverages, starting with insurance for potential worker and offsite losses, continuing with individual self-insurance for onsite losses, and concluding with a post-funded industry insurance pool for unlikely potential losses that might exceed the limits for commercial insurance or individual self-insurance. This structure is discussed below and summarized in Table A-12. 
Table A-12. Summary of a potential financial assurance program for a hypothetical LLW disposal facility.

\begin{tabular}{ll}
\hline Potential loss type & \multicolumn{1}{c}{ Provide assurance by: } \\
\hline Claims from workers & Workers Compensation Insurance \\
Onsite cleanup costs & $\begin{array}{l}\text { Individually self-insured (prefunded) to } \$ 2.5 \text { million } \\
\text { Individually self-insured (postfunded) for potential losses in } \\
\text { excess of } \$ 2.5 \text { million }\end{array}$ \\
& $\begin{array}{l}\text { Commercially insure to available limit (currently } \$ 25 \text { million) } \\
\text { Offsite liability claims }\end{array}$ \\
& $\begin{array}{l}\text { Self-insure either individually or through an industry } \\
\text { sponsored pool for potential losses in excess of the } \\
\text { commercial insurance limit. }\end{array}$ \\
\hline
\end{tabular}

\section{A-5.2.1 Workers' Compensation Insurance}

Workers' Compensation insurance can be readily purchased on a "no limits" basis from several different insurance companies. Workers' Compensation coverage does not require purchasing a certain limit of protection; rather, it covers the benefits determined by State law. The Coverage B section (Employers Liability) of the Workers' Compensation policy does require specifying a limit. As noted in the text, if workers sued for injury beyond that covered under Workers' Compensation insurance, judgements would likely be paid under the Employer's Liability section. Although this portion of the insurance policy is rarely utilized (the vast majority of claims comes under the traditional Workers' Compensation Coverage A section), a limit of $\$ 1.1$ million should be sufficient for the cumulative $\$ 1.0$ million loss estimated for worker claims from operational accidents.

\section{A-5.2.2 Onsite Costs}

Onsite costs cannot currently be covered by the insurance market. Therefore, an alternative mechanism must be developed. Use of prefunded, site-specific self-insurance of $\$ 2.5$ million would cover most of the potential $\$ 3.9$ million onsite loss for premature vault failure. Prefunding beyond $\$ 2.5$ million could be economically counterproductive, and additional protection might be better accomplished through an individually self-insured, postfunded pool.

\section{A-5.2.3 Offsite Liability}

Currently, insurance is available only from American Nuclear Insurers (ANI) for potential losses to offsite parties, up to a $\$ 25$ million limit. Purchase of such coverage is an efficient method of covering most of the potential $\$ 44.7$ million offsite loss if an extreme natural event were to occur. The remainder could be provided for by self-insuring either individually or through an industry sponsored pool.

If offsite liability insurance were not available, most conventional industries would look seriously at self-insuring this unlikely potential loss through a postfunded mechanism. Such a mechanism would 
likely use enforceable postfunding agreements with users of the facility or others in the self-insurance group.

Because of the hypothetical nature of the facility used in this evaluation, the values presented in these results cannot be generalized. A financial assurance program for any actual $L L W$ disposal facility must be determined on the basis of site-specific analyses and policy decisions. The availability of an industry insurance pool is contingent upon agreement among Compacts and States. To date no discussions have been held to seriously consider this possibility.

\section{A-6. IMPLEMENTATION AND ADMINISTRATION OF FINANCIAL ASSURANCE PLAN}

It is assumed in this report that the financial assurance mechanisms chosen must stay in place and be available to pay potential losses for at least 100 years after closure.

The implementation and administration of the chosen mechanisms vary greatly. The following sections discuss how to implement either insurance, self-insurance, or an insurance pool, and the administrative issues relating to these mechanisms.

\section{A-6.1 Currently Available Commercial Insurance}

Commercial insurance would be the easiest mechanism to implement and administer. It would require three things:

- $\quad$ Determining the type and level of insurance needed

- Ensuring availability of the needed insurance

- Monitoring to ensure the type and level of insurance needed is maintained.

For purposes of this illustration, three types of commercial insurance are needed, but only two are currently available. Insurance is needed to cover potential claims for job-related injuries by workers, onsite damages, and offsite damages. As previously noted, however, only insurance for job related worker injuries (Workers Compensation) and offsite damages (ANI) can currently be obtained. It is assumed that the needed Workers Compensation coverages will remain readily available because it is required by all States. Therefore, this discussion focuses primarily on planning continued insurance coverage for potential offsite damages.

If commercial insurance is utilized, the insurance should be purchased by the facility operator as part of its responsibilities under the management contract, through traditional insurance sources (e.g., insurance brokers). The only company currently offering offsite liability insurance, ANI, deals exclusively through insurance brokers, which would ease the administrative burden on the facility operator.

Premiums for the insurance could be paid by a surcharge on the disposal fee. The charge to the generator could be based upon the actual contribution to the insurance premium resulting from 
disposal of a particular type of waste. Thus, the surcharge on Class $A$ waste might be different from the surcharge on Class B or Class $\mathrm{C}$ waste, as established by the facility operator.

Currently, offsite liability insurance provides coverage for 10 years after the policy is terminated. Therefore, if the operator of a facility were to cancel its insurance upon closure, only claims made within 10 years after closure would be covered. Because claims could be made anytime after closure, some form of coverage should be maintained for a minimum period established by the facility regulator.

Ensuring continued insurance coverage, however, might be difficult to accomplish for two reasons. First, insurers might withdraw from the market and, second, facilities must ensure payment of insurance premiums after the site is closed and no revenue is being generated. The best way to address the first issue is to have a less-than-expected claims rate. Developers, operators, and regulators are confident that this will be the case for all new disposal facilities.

Ensuring payment of insurance premiums after site closure is difficult because of the rapid changes in legal, social, and insurance interpretations of environmental liabilities. Therefore, a conservative estimate would need to be developed of the total premium needed. This estimated amount would be collected by the site operator during operations and placed in a fund for the future purchase of required insurance.

Another option for maintaining a form of insurance after closure might involve the purchase of so-called "tail" coverage. Tail coverage is purchased once the insured's activities cease and covers long-term potential liabilities originally insured under claims-made insurance forms. To maintain tail coverage, a facility operator might be required to renew the insurance periodically during the ensuing 100 years, or to simply make one final insurance premium payment.

The major risk in paying for insurance coverage after closure is that the early projections of premium costs may prove inadequate. One way to minimize this risk to the disposal facility is to collect a surcharge substantially above the level that is expected to be necessary. At the end of the post-closure period, excess funds could be returned to generators that can still be located.

Alternatively, a less-structured postclosure financial guarantee could be established. For example, if the postclosure insurance premium is higher than expected, the waste generators would make up the difference, even though some waste generators may be too small to provide acceptable guarantees or may no longer be in business when the extra money is needed.

As financial assurance mechanisms for LLW disposal facilities are developed, negotiations should be conducted with the insurance industry, facility operators, and waste generators to establish a reasonable, economically efficient, safe insurance charge. Currently, only limited pricing information on insurance is available to develop a methodology for collecting sufficient funds to pay premiums during facility operations and after facility closure. If the insurer is unable or unwilling to revise its underwriting procedures and insurance policy form to automatically include post-closure coverage, a fund would need to be established to hold excess premiums collected during the active life of the facility to make premium payments after closure. The income from these deposits should be invested conservatively to earn interest that can help protect against potential increases in premium rates. 


\section{A-6.2 Self-Insurance}

Self-insurance for an individual facility will be somewhat more complex than using commercial insurance. To implement a self-insurance program, specific actuarial and underwriting studies would need to be conducted for each facility to develop a summary of estimated costs. A self-insurance administration company would probably not be needed to run the self-insurance program since there would be little or no claims activity. However, a team of consulting experts would be necessary for each facility. This team would include:

- $\quad$ Actuaries

- Legal support

- Risk management consultant

- Engineering consultant.

All of these experts would be readily available and not particularly expensive in relation to the premiums collected for the self-insurance fund.

A periodic audit of the adequacy of the funds would be necessary to assure State and federal regulators of the soundness of the financial assurance program. An audit of premium adequacy and underwriting procedures should be conducted approximately every three years. This is particularly important since self-insurance programs often operate without the oversight of State insurance regulators.

The tendency in most self-insurance programs that have few or no losses is to believe that losses will never occur. This generates pressure to reduce or eliminate new contributions. However, this would be improper and dangerous, since the actuarial projections expect very few, if any, losses but show the need to have sufficient funds available. Thus, an audit of premium adequacy and underwriting procedures on a regular basis needs to occur to protect against the tendency to assume charges are excessive or unnecessary.

\section{A-6.3 Insurance Pool}

The most complex and possibly the most effective financial assurance option is the use of an insurance pool protecting most or all LLW facilities against potentially large losses. Such a pool would effectively operate as a small, single-purpose insurance company that would only provide liability protection for LLW facilities. Because it would protect many facilities, it would need to operate more formally than an individual self-insurance program. Thus, it would require a staff, outside services, administrative offices, and marketing resources.

If an insurance pool were established for several LLW facilities, it would take substantially more implementation time than either the purchase of insurance or self-insurance. Insurance and selfinsurance can be arranged almost immediately before initial start-up of a facility. In contrast, an insurance pool would need to be developed and in place well in advance of facilities being 
established. It would take one to two years to put a pool in place from the time the concept is approved by the appropriate bodies.

Funding is needed to create such a pool since costs would be incurred for underwriting, engineering, risk management, and actuarial work, in addition to the staff needed to organize and implement the pool. It is assumed that a single staff person with secretarial support would probably be necessary during the first year of startup. Funding would be necessary not only for personnel costs but also for travel and consultants. An annual budget of about $\$ 200,000$ would be appropriate during the startup phase, broken down as shown in Table A-13.

Table A-13. Annual budget for startup phase.

Staff salary and overhead

Secretarial support and overhead

Office space, travel budget, etc.

Consultants

Total Startup Costs
$\$ 75,000$

$\$ 30,000$

$\$ 25,000$

$\$ 70,000$

One alternative is to establish a pool under the management of $\mathrm{ANI}$, the only company offering insurance for LLW disposal facilities. This may be an effective way to secure the necessary expertise and services if ANI is unwilling to provide the needed coverage.

At this stage, there is no indication that ANI or any other insurance company is willing to operate a pool on behalf of the LLW disposal facility operators. It is possible they would find this prospect appealing, since they would have the benefit of continuing to provide services for potential liabilities, without the risk of financial losses. If it were ultimately determined that a combination of insurance and pooled self-insurance were appropriate, administration of the pool by an insurance company would be very logical. 


\section{A-7. REFERENCES}

1. U.S. Department of Energy, Prototype License Application: Safety Analysis Report, Belowground Vault, Low-Level Waste Management Program, DOE/LLW-72T, October 1988. 


\section{Appendix B}

Reference Disposal Facility Description 


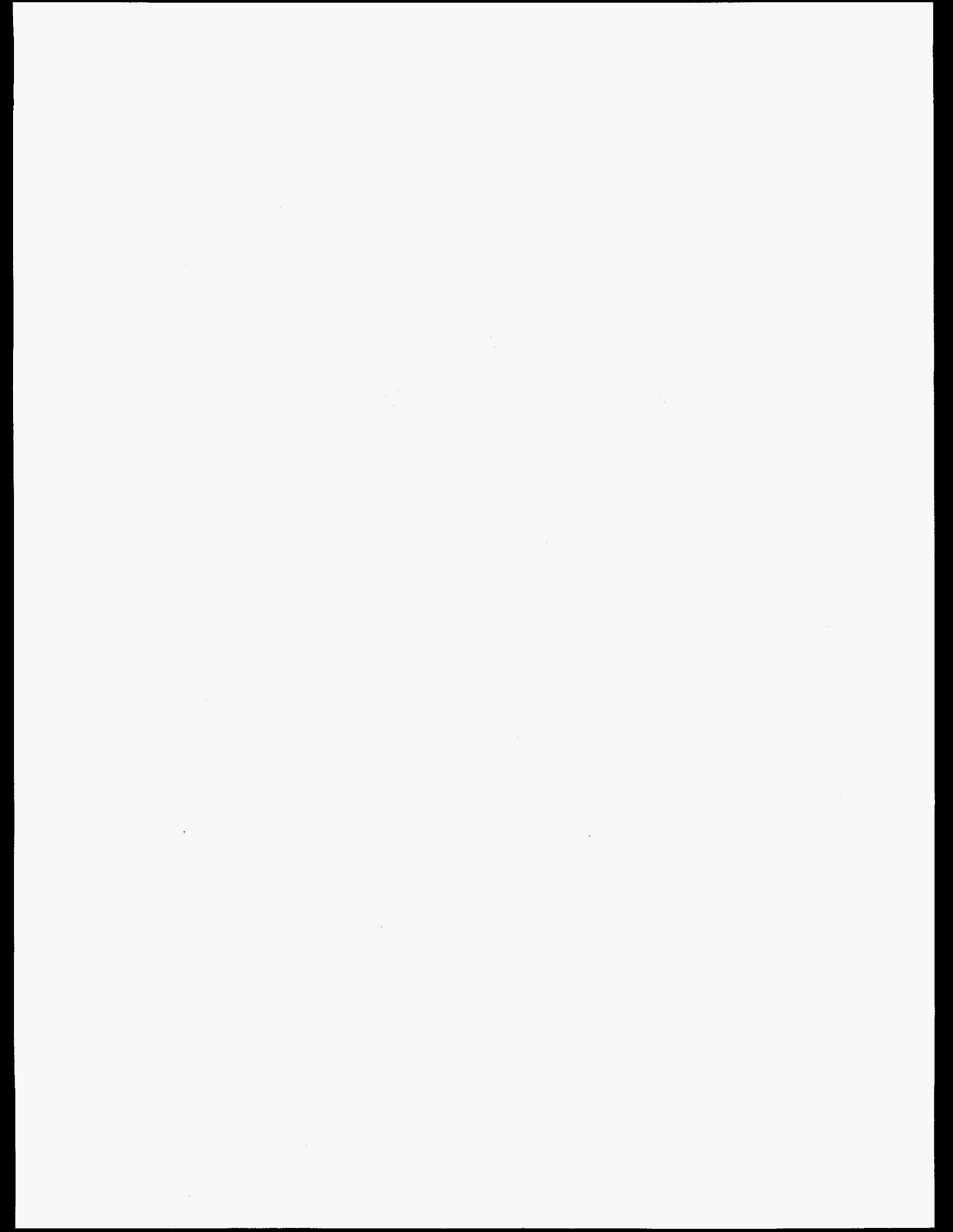




\section{Appendix B}

\section{Reference Disposal Facility Description}

\section{B-1. INTRODUCTION}

This appendix provides a description of the belowground vault (BGV) disposal system, which is the reference disposal concept used in preparing this report. Information is included about the reference site, the reference disposal facility, the radioactive waste inventory, and the chronology of potential financial liability mechanisms. This information is based on the site and facility description in the prototype license application for belowground vault disposal prepared for the U.S. Department of Energy's Low-Level Waste Management Program. ${ }^{1}$

Belowground vault disposal consists of placing the waste in engineered concrete structures located below natural grade. The structures consist of reinforced concrete floors, walls, and roof. In addition, since the vaults are constructed below grade, they are covered with an earthen cover. A schematic representation of a BGV unit is shown in Figure B-1.

The reference disposal facility is assumed to be located in a rural setting in the northeastern United States. The BGV is designed for an annual disposal capacity of $235,000 \mathrm{ft}^{3} / \mathrm{yr}$ and operates for 30 years. Only commercial low-level radioactive waste (LLW) is accepted at the facility. No mixed hazardous and low-level radioactive waste (mixed waste), or greater-than-Class C LLW will be accepted. Waste from decontamination and decommissioning of the disposal facility at the end of its operational lifetime will be disposed of on site and can be accommodated within the volume for which the facility is designed.

Class A waste, as defined by 10 CFR 61, is placed in Class A disposal units. The Class A disposal units have a design life of at least 100 years and are physically separate from the Class $\mathrm{B} / \mathrm{C}$ disposal units. The Class $\mathrm{B} / \mathrm{C}$ disposal units, which contain all Class $\mathrm{B}$ and $\mathrm{C}$ wastes, have a design life of at least $\mathbf{5 0 0}$ years. The individual disposal units are constructed sequentially, as needed, using "cut and cover" construction. Individual units are sized to accommodate approximately one year of Class $A$ waste, and two years of Class B and $C$ waste.

\section{B-2. SITE DESCRIPTION}

\section{B-2.1 Location of the Facility}

The disposal site is in a rural location in the coastal plain region of the northeastern United States. The disposal site is a 217 -acre rectangular parcel of land that includes a 328 -ft wide buffer zone around the operational area. Approximately 134 acres are used for disposal. 


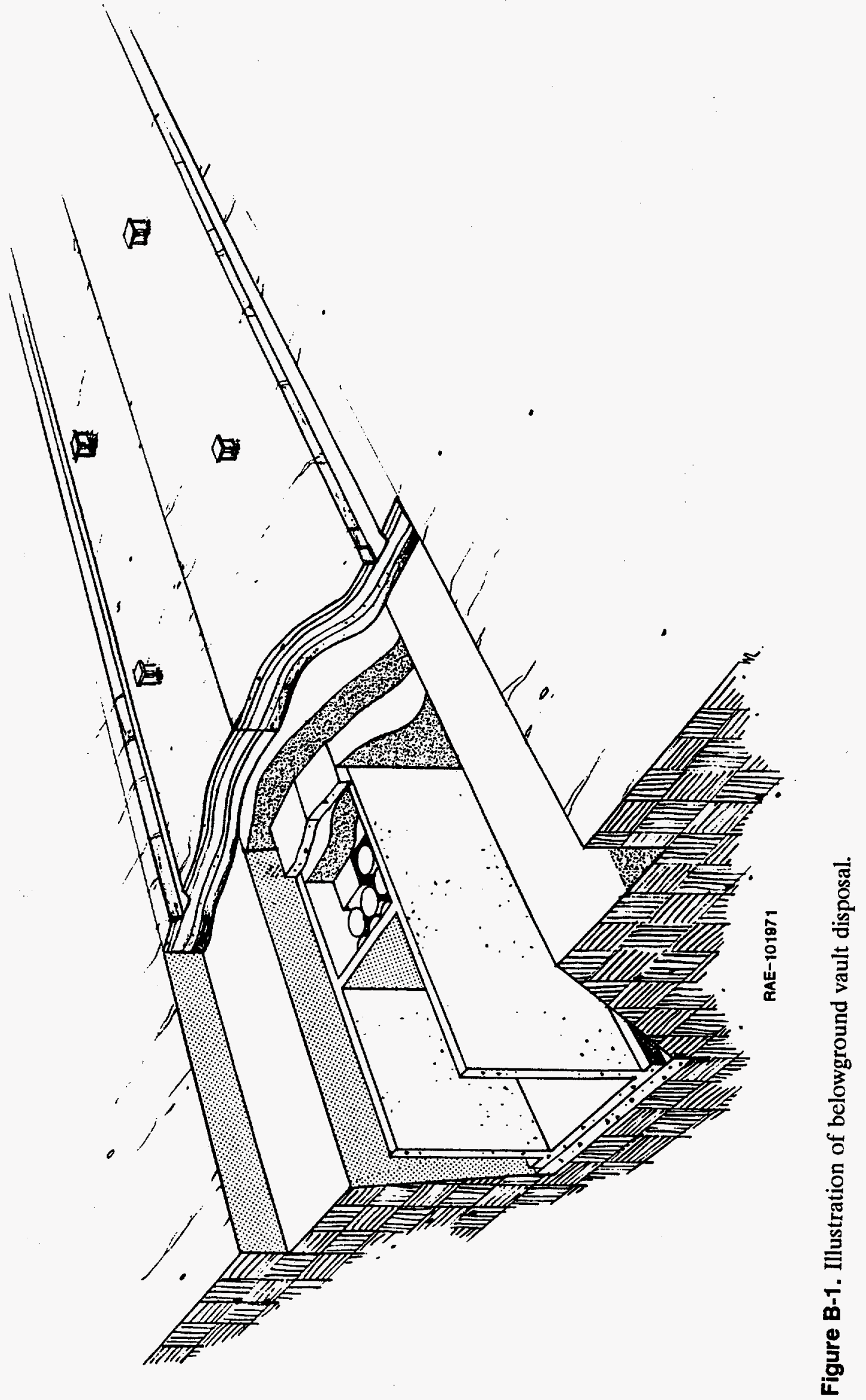




\section{B-2.2 Population Distribution}

The closest incorporated area is located $2.2 \mathrm{mi}$ to the north and has a resident population of 4,285. Another village is located $5.5 \mathrm{mi}$ east-northeast and has a resident population of 1,113 . The closest residence to the site is a farm approximately $1.0 \mathrm{mi}$ from the site boundary. The population distribution for the area within $\mathbf{6 . 2}$ mi of the site is tabulated by distance and direction in Figure B-2. As shown in the figure, the density of the population in the immediate area surrounding the site is low. Most workers at the disposal site commute from the villages or from other cities within a $31 \mathrm{mi}$ radius of the site. The total population within a 31 -mi radius of the site is about 250,000 persons.

\section{B-2.3 Meteorology and Climatology}

The general climate is typical of the humid continental climate encountered in the northeastern United States and is characterized by moderate to severe winters, long periods of mild weather in the autumn, somewhat more windy but mild weather in spring, and warm summers.

Mean annual precipitation is 46.7 in. per year. Heavy precipitation associated with thunderstorms is fairly common in late summer. The maximum recorded 24 -hr precipitation is 7.84 in. The number of heavy hail greater than 0.25 in. in the site area is approximately seven in 13 years, or once in two years. Fastest mean monthly winds occur in winter ( 7 to $8 \mathrm{mph}$ ). The speed of the fastest wind during a 20 -year period is $62 \mathrm{mph}$. Strong winds associated with thunderstorms, with wind speeds up to $35 \mathrm{mph}$, are observed in late summer and early autumn. Hurricane-force winds do not extend inland on the site. There is no history of flooding at the site. An analysis of the effects of potential dam failures showed that probable maximum flood conditions would not inundate the disposal site, as shown in Figure B-3.

\section{B-2.4 Seismology}

All historically reported earthquakes of magnitude greater than or equal to modified Mercalli intensity IV or magnitude 3.0 are shown in Figure B-4. An explanation of the modified Mercalli intensity scale is given in Table B-1. Best data indicate that a major earthquake at the site would range in intensity from VI-VII to VII. Probabilistic estimates for the seismic region in the vicinity of the disposal site indicate that an earthquake resulting in a $0.20 \mathrm{~g}$ acceleration has a 250 year return interval with a $90 \%$ probability of not being exceeded.

\section{B-2.5 Hydrology}

The disposal site is located on a drainage divide with minimal upgradient drainage area. Aquifers in the site area form a simple-layered groundwater system. The unconfined aquifer is recharged by rainfall. About $18 \mathrm{in.} \mathrm{of} \mathrm{water} \mathrm{annually} \mathrm{percolates} \mathrm{and} \mathrm{recharges} \mathrm{the} \mathrm{aquifer.} \mathrm{The}$ confined aquifer is recharged from outcrops and stream beds more than $11 \mathrm{mi}$ northwest and upgradient of the disposal site. A clay layer, approximately $10 \mathrm{ft}$ thick at the disposal site location separates the two aquifers and serves as an aquitard. All of the disposal units at the disposal site are located in the unsaturated zone above the unconfined aquifer. 


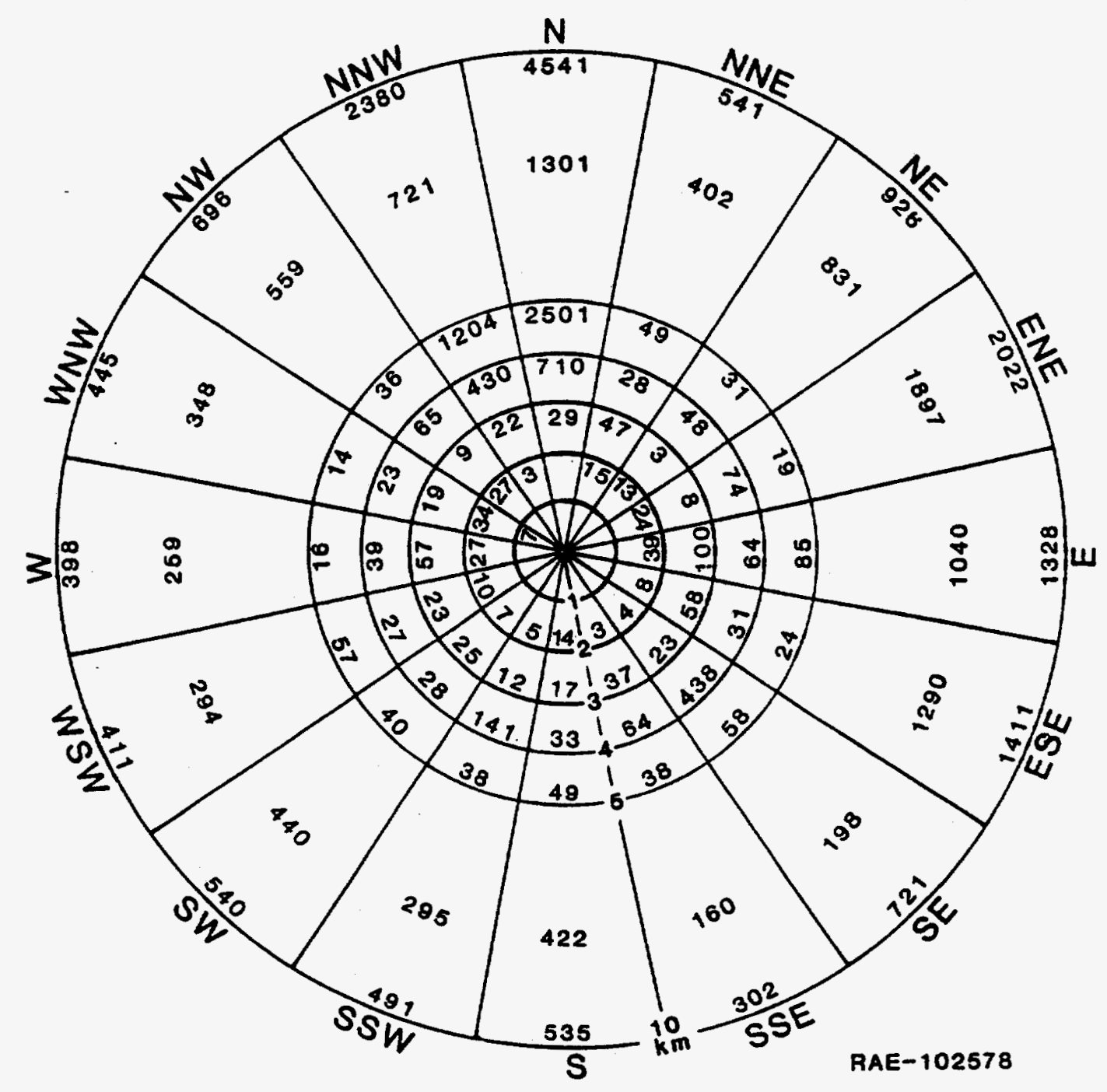

Figure B-2. Population estimates by sector for 1980 census data (annular distances in kilometers). 


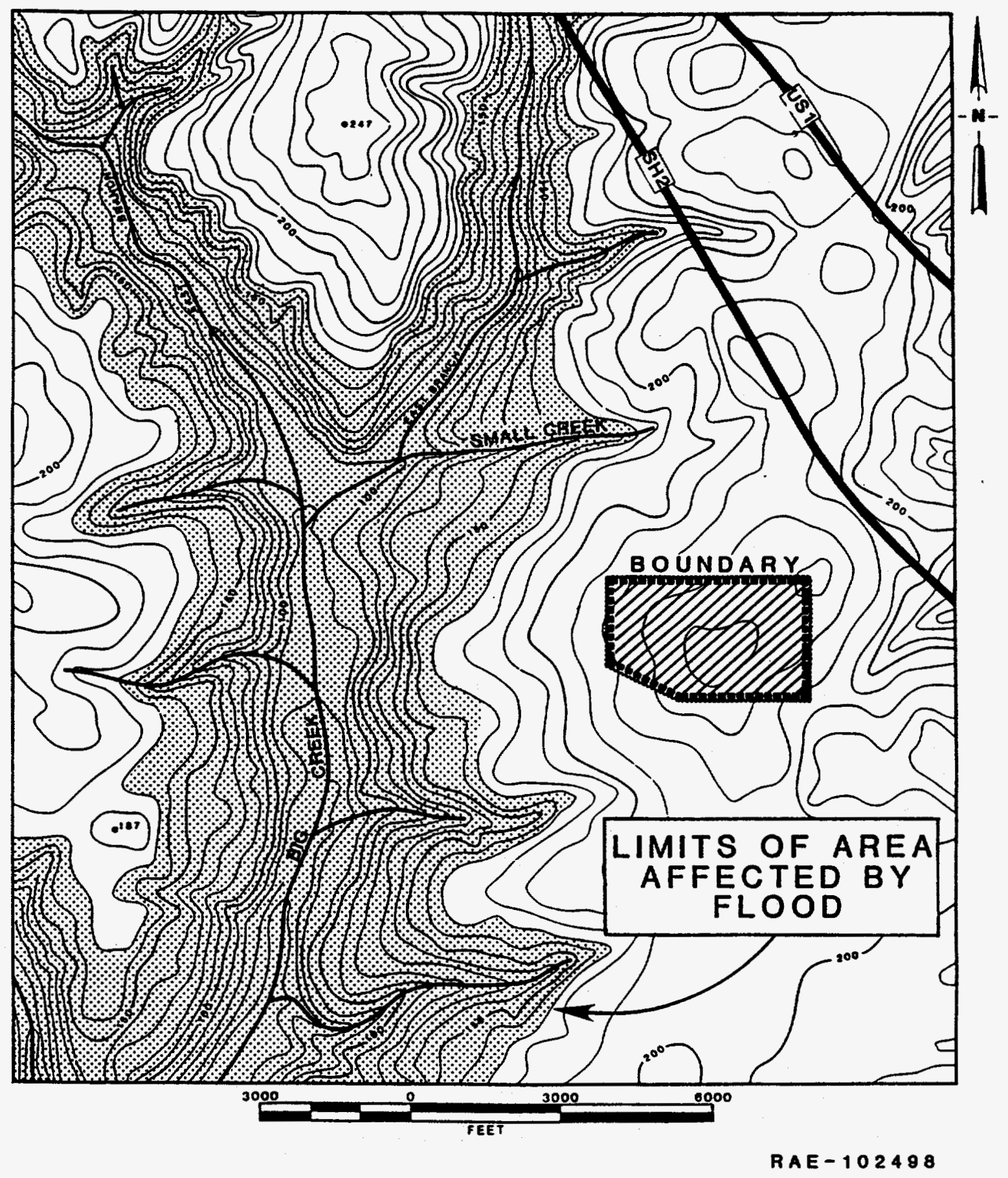

Figure B-3. Area affected by maximum flood conditions. 


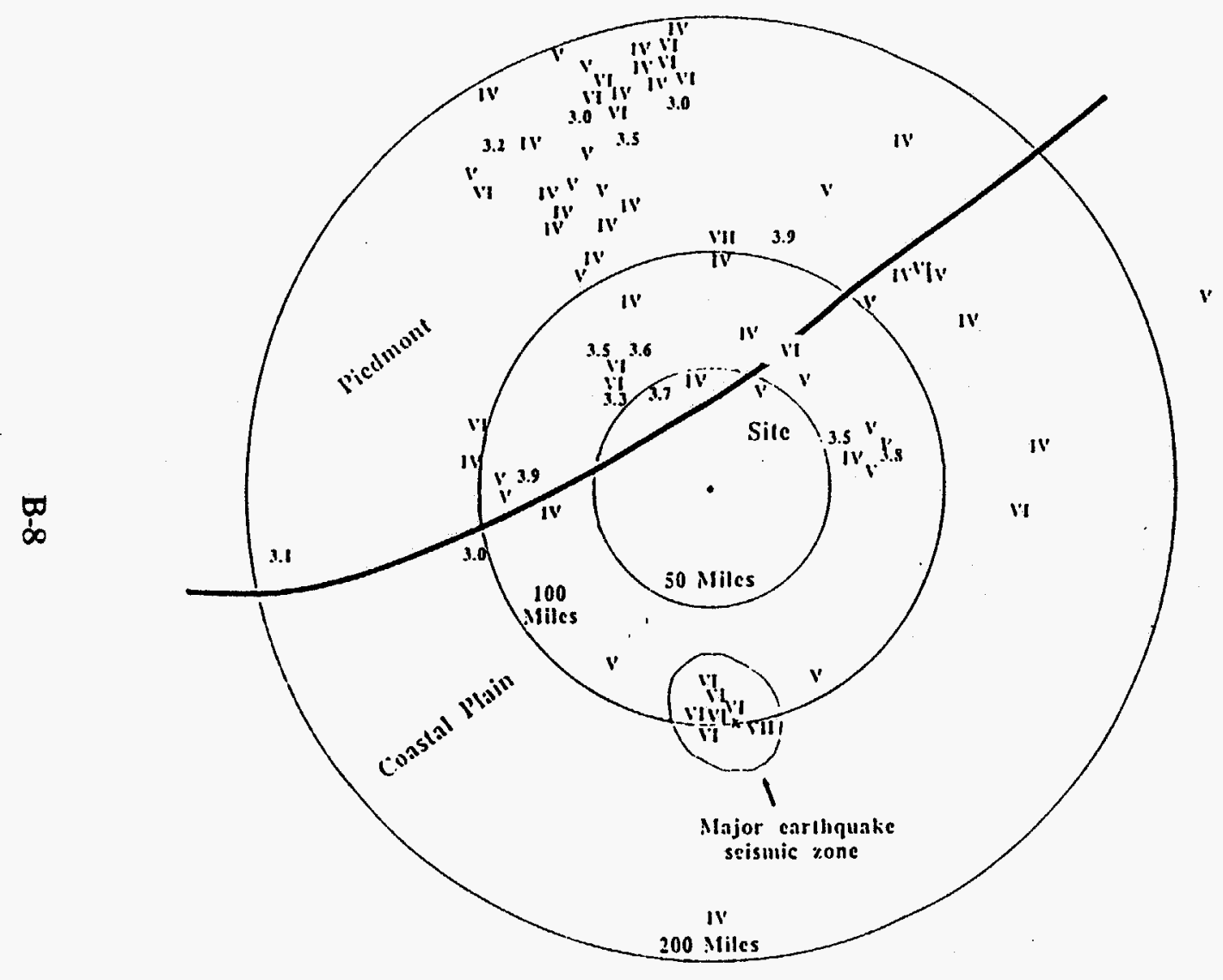

Explanation

- Boundary of scisnic source areas used in sile selcetion

v Modilled Mcrealli intensily plotted at the eartinquake epicenter

3.0 Magnilude plutied of lise e cpicemer

dII cartigquakes betucen liz and 10sz with intensity prealer or toual 10 mo are sher

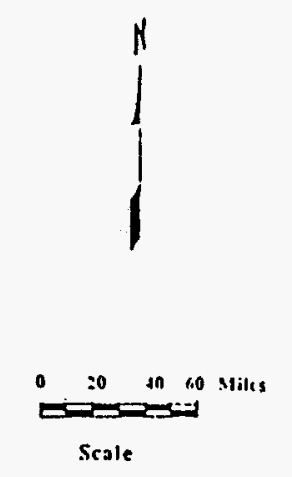

RAE- 102438

Figure B-4. Location of significant seismic activity in the region surrounding the site. 
Table B-1. Modified Mercalli Intensity Scale of 1931 (abridged).

I. Not felt except by a very few under especially favorable circumstances (I Rossi-Forel Scale).

II. Felt only by a few persons at rest, especially on upper floors of buildings. Delicately suspended objects may swing (I to II RossiForel Scale).

III. Felt quite noticeably indoors, especially on upper floors of buildings, but many people do not recognize it as an earthquake. Standing motor cars may rock slightly. Vibration like passing truck. Duration estimated (III Rossi-Forel Scale).

IV. During the day felt indoors by many, outdoors by few. At night some awakened. Dishes, windows, doors disturbed, walls make creaking sound. Sensation like heavy truck striking building. Standing motorcars rocked noticeably (IV to V Rossi-Forel Scale).

V. Felt by nearly everyone, many awakened. Some dishes, windows, etc. broker, a few instances of cracked plaster. Unstable objects overturned. Disturbance of trees, poles, and other tall objects sometimes noticed. Pendulum clocks may stop (V to VI RossiForel Scale).

VI. Felt by all, many are frightened and run outdoors. Some heavy furniture moved, a few instances of fallen plaster or damaged chimneys. Damage slight (VI to VII Rossi-Forel Scale).

VII. Everybody runs outdoors. Damage negligible in buildings of good structures. Considerable in poorly built or badly destined structures. Some chimneys are broken. Noticed by persons driving motorcars (VIII Rossi-Forel Scale).

VIII. Damage slight in specially designed structures; considerable in ordinary substantial buildings with partial collapse, great in poorly build structures. Panel walls thrown out of frame structures. Fall of chimneys, factor stacks, columns, monuments, walls. Heavy furniture overturned. Sand and mud ejected in small amounts. Changes in well water. Disturbs persons driving motorcars (VII to IX Rossi-Forel Scale).

IX. Damage considerable in specially designed structures; well designed frame structures thrown out of plumb; great in substantial buildings, with partial collapse. Buildings shifted off foundations. Ground cracked conspicuously. 
The closest discharge of groundwater to the surface occurs more than $5,000 \mathrm{ft}$ from the disposal site boundary. There is some pumping from the unconfined aquifer for water supply purposes, but this is only from small wells that serve single residences or small farms. Most of the large groundwater users tap the confined aquifer. A survey was made of groundwater use in an area within about $20 \mathrm{mi}$ from the site. This survey found that the groundwater is the primary source of water for domestic, industrial, municipal, and agricultural use in the vicinity of the site. The survey identified 24 municipal users and 20 agricultural and industrial users. The locations of these groundwater users are shown in Figure B-5.

Values of the parameters used to characterize the groundwater pathways for radiological impacts from the reference disposal facility are presented in Table B-2.

\section{B-3. FACILITY DESCRIPTION}

\section{B-3.1 General Information}

The BGV disposal facility site plan is shown in Figure B-6. Approximately $235,000 \mathrm{ft}^{3}$ of lowlevel radioactive waste will be sent to the disposal facility annually for 30 years. Waste classified as Class $\mathrm{A}$ will be disposed of in disposal vaults that are separated from the vaults used for the disposal of Class B and $C$ waste. The individual disposal vaults will be constructed sequentially, as needed, and will be sized to accommodate approximately one year of Class A waste, and two years of Class B and $C$ waste. As shown in Figure B-6, there will be three large clusters of Class $A$ waste vaults, 10 vaults to a cluster, and 15 Class $B / C$ vaults.

The administrative area between the outer and inner fences contains facilities for administrative functions, waste receipt and inspection, environmental sample analysis, and surface water treatment. Environmental monitoring and surface water drainage control are also performed in this buffer zone area.

The area inside the inner fence includes the general support area and the Class $\mathrm{A}$ and Class $\mathrm{B} / \mathrm{C}$ disposal areas. The general support area includes facilities for disposal area access control, temporary waste storage, waste testing, vehicle decontamination, contaminated water treatment, drainage retention, and health physics support. Environmental monitoring and surface water drainage control are also performed within the disposal area inside the inner fence.

\section{B-3.2 Physical Security}

Physical security for the facility is provided by the two chain-link fences and security personnel. The fence is patrolled several times each day and no electronic surveillance is maintained. The vehicle gate into the waste disposal area is monitored and controlled 24 hours per day, seven days per week by security personnel in the Operations Support Building. There are two personnel entrances into the waste disposal area, one through the security station in the Operations Support Building and one through the control point in the Receiving and Storage Building. This entrance point and its normal exit point are visible from the security station. There is also a security officer in the guard house located at the outer fence during operating hours. After hours the entrance gate at the outer fence is closed and monitored from the security station. Alarms are activated at the 


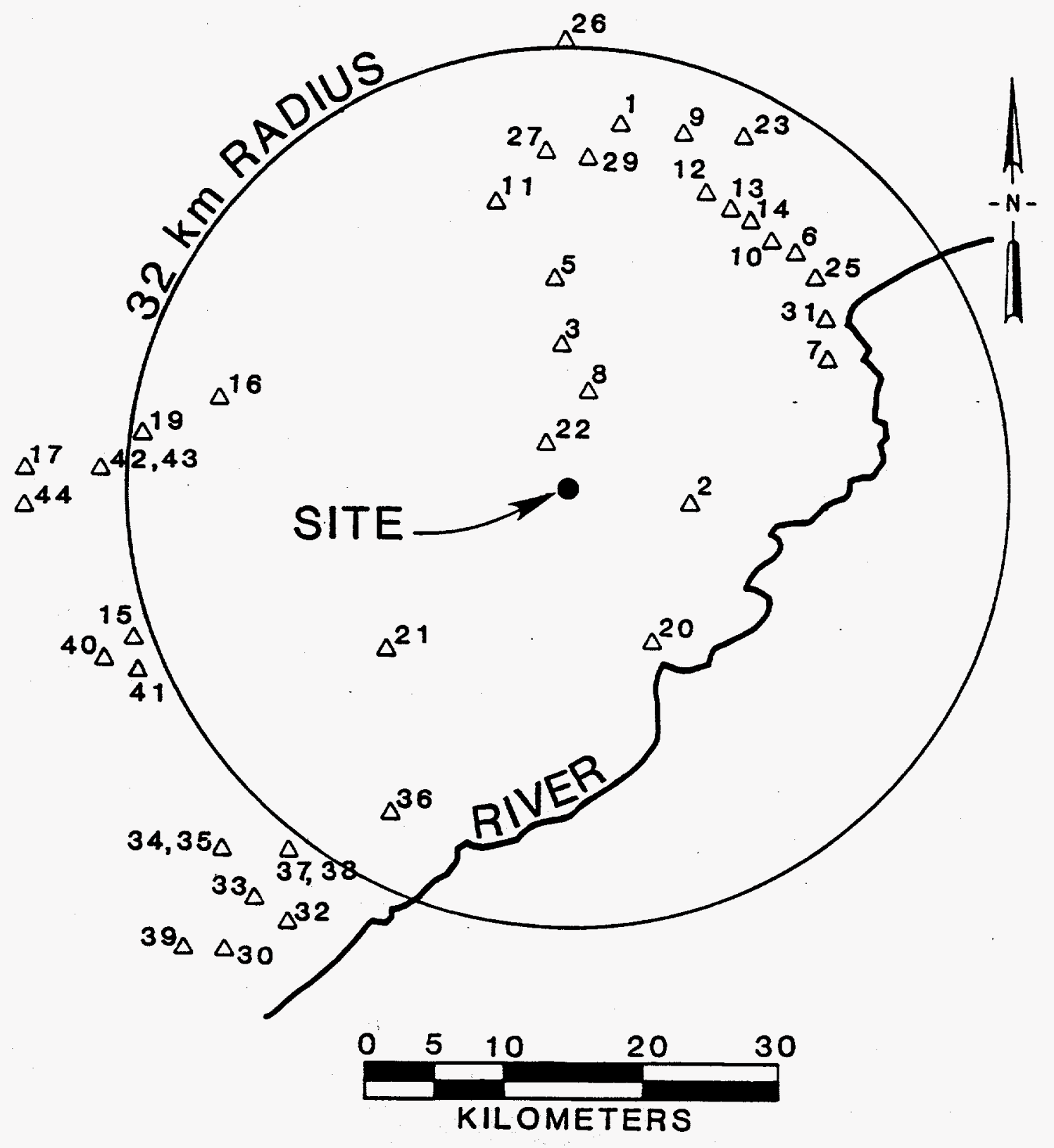

RAE-102506

Figure B-5. Location of industrial, agricultural, and municipal groundwater users. 
Table B-2. Groundwater pathway parameters.

Parameter

Value

Distance from water to aquifer

Class A vaults

$25 \mathrm{ft}(7.6 \mathrm{~m})$

Class $B / C$ vaults

$18 \mathrm{ft}(5.5 \mathrm{~m})$

Percolation through cover

Class A vaults

10 in. $(25 \mathrm{~cm} / \mathrm{yr})$

Class $B / C$ vaults

1.5 in. $(4 \mathrm{~cm} / \mathrm{yr})$

Vault design lifetime

Class A

$200 \mathrm{yr}$

Class B/C

$500 \mathrm{yr}$

Porosity of unsaturated zone

0.48

Average moisture in unsaturated zone

74 percent

Average vertical water velocity

$3 \mathrm{ft} / \mathrm{yr}(1 \mathrm{~m} / \mathrm{yr})$

Percolation through watershed

$18 \mathrm{in} . / \mathrm{yr}(45 \mathrm{~cm} / \mathrm{yr})$

Hydraulic conductivity of aquifer

$5.0 \mathrm{E}-04 \mathrm{~cm} / \mathrm{sec}$

Hydraulic gradient in aquifer

0.006

Porosity of aquifer

0.30

Aquifer velocity

$10 \mathrm{ft} / \mathrm{yr}(3 \mathrm{~m} / \mathrm{yr})$

Distance to well

$328 \mathrm{ft}(100 \mathrm{~m})$

Distance to river

$1.4 \mathrm{mi}(2,300 \mathrm{~m})$

River flow rate

$3.3 \mathrm{E}+11 \mathrm{ft}^{3} / \mathrm{yr}$

$\left(9.3 \mathrm{E}+09 \mathrm{~m}^{3} / \mathrm{yr}\right)$ 


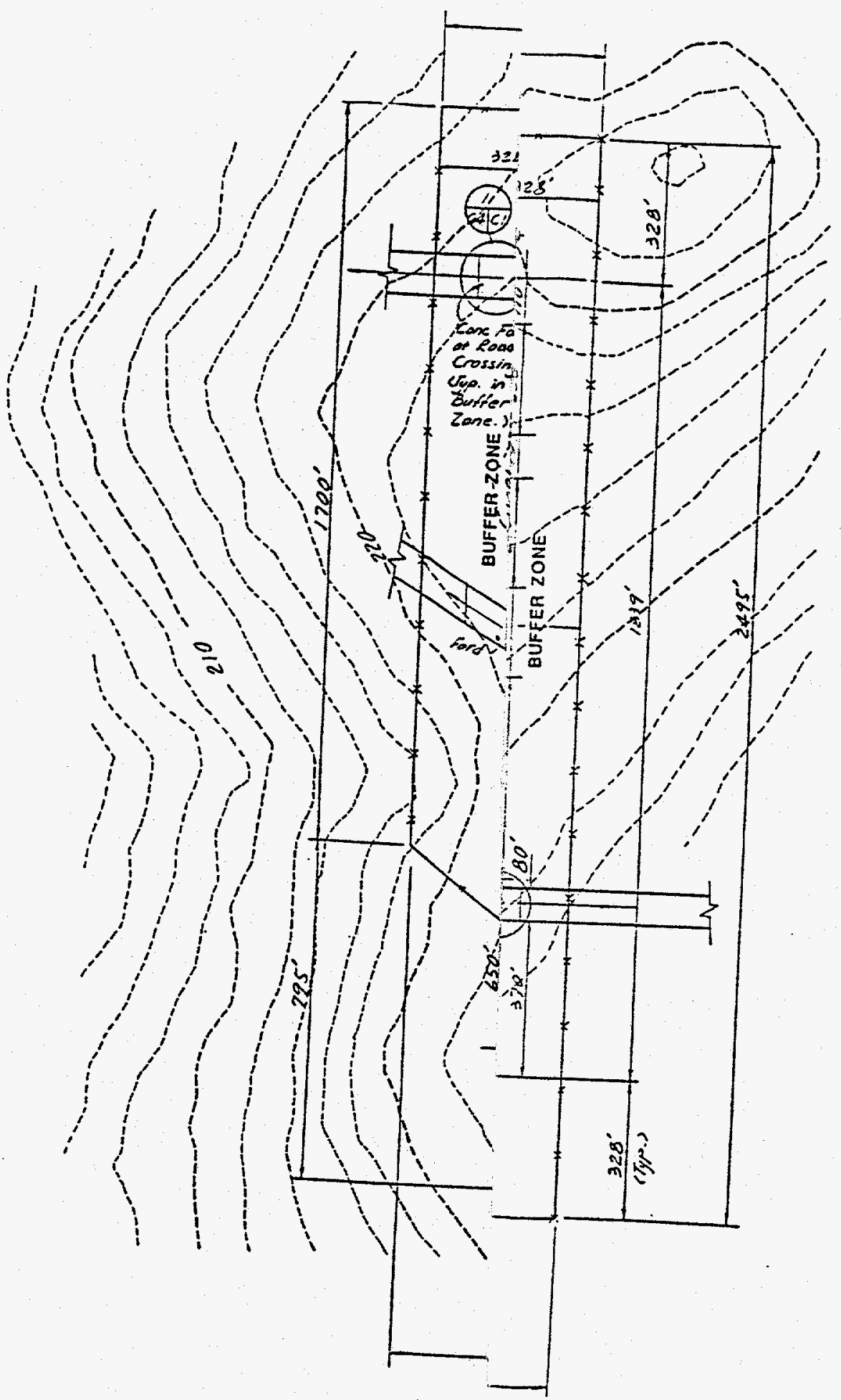

1

SYMBOL:

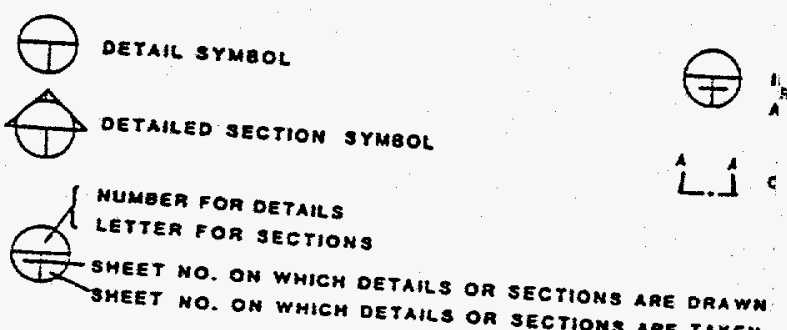

Figure B-6. Prototype licensing project-belowgrour AUCTION

\begin{tabular}{|c|c|}
\hline \multicolumn{2}{|c|}{\begin{tabular}{|c|} 
Rogers \& Associates Engineering Corporation \\
p.o. Box
\end{tabular}} \\
\hline 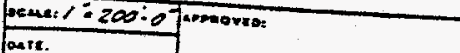 & 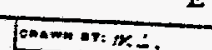 \\
\hline EG\&G Idahn & neroses: \\
\hline $\begin{array}{l}\text { Prototype Licensing Project } \\
\text { Below Ground Veult }\end{array}$ & $\begin{array}{l}\text { DISPCSAL } \\
\text { SITE PLAN } \\
\end{array}$ \\
\hline
\end{tabular}


security station and the guard house whenever a door to an emergency exit is opened. Security personnel perform a total perimeter inspection three times a day.

\section{B-3.3 Disposal Units}

Containers of radioactive waste received at the facility are disposed in steel-reinforced concrete vaults located wholly below natural grade and covered with an earthen cover system after the waste is disposed. Parameters that characterize the concrete disposal vaults are presented in Table B-3. Class A vaults are designed to contain the waste without loss of structural integrity for at least 100 years. Class $A$ vaults are constructed of steel-reinforced concrete and are coated with a thick layer of asphalt for additional protection against infiltration. Each group of nine cells is closed with the construction of a concrete roof when all cells have been filled with waste containers and voids backfilled with pea gravel.

Class $\mathrm{B} / \mathrm{C}$ vaults are designed to contain the waste without loss of structural integrity for at least 500 years. The concrete roofs over the Class $\mathrm{B} / \mathrm{C}$ vaults also serve as inadvertent intruder barriers. These vaults are constructed of steel-reinforced concrete. Each vault is comprised of two structurally independent groups of three disposal cells each, making six disposal cells per vault. The Class $\mathrm{B} / \mathrm{C}$ vaults employ water resistant coatings on both exterior and interior surfaces to protect the concrete and limit water infiltration. Each group of three disposal cells is provided with a steel-reinforced concrete roof after it is filled with waste containers and the voids are backfilled with pea gravel.

\section{B.3.4 Disposal Unit Cover Systems}

As soon as possible after a vault is filled and its roof constructed, the earthen cover system is placed over the vault. Initially, an interim cover system is placed. After structural stability and acceptable environmental performance have been demonstrated through monitoring and surveillance, the top portion of the interim cover system is removed and the final cover system is placed.

\section{B-3.5 Surface Water Drainage System}

A surface water drainage system is provided to minimize run-on of water that originates in land areas outside the disposal site, to conduct precipitation that falls on the disposal site away from the disposal units, to limit the amount of precipitation that can infiltrate into the disposal units, and to limit the potential for erosion caused by water as it drains from the site.

The surface water drainage system includes the natural contours of the site, a system of drainage ditches around each disposal unit, and a system of storm drainage collection channels. The ditches are sized to conduct all runoff water resulting from the 100-year 6-hour rainfall event without overflowing. Because of the topography of the site, there is no need to provide the site with berms to prevent run-on.

\section{B-3.6 Monitoring}

Environmental monitoring programs are conducted during the operational, closure, and postclosure periods of the facility to ensure early detection of any releases of radionuclides from the 
Table B-3. Parameters used to characterize concrete disposal vaults.

Value

Parameter

Cell dimensions ( $\mathrm{L} \times \mathrm{W} \times \mathrm{H})$

Exterior wall thickness

Internal wall thickness

Floor overhang from external wall

Static load on roof

Roof thickness

Floor thickness

Arrangement of waste cells in construction unit

Concrete cover thickness on steel

Roof

Floor

Steel radius

Steel spacing
Class A

$286 \times 286 \times 290$ in.

$(7.3 \times 7.3 \times 7.4 \mathrm{~m})$

26 in. $(66 \mathrm{~cm})$

18 in. $(45 \mathrm{~cm})$

41 in. $(104 \mathrm{~cm})$

$6.7 \mathrm{psi}$

26 in. $(66 \mathrm{~cm})$

38 in. $(97 \mathrm{~cm})$

$3 \times 3$

3. in $(7.6 \mathrm{~cm})$

3.5 in. $(8.9 \mathrm{~cm})$

$.438 \mathrm{in} .(1 \mathrm{~cm})$

12 in. $(30 \mathrm{~cm})$
Class B/C

$288 \times 294 \times 294$ in.

(7.3 x $7.5 \times 7.5 \mathrm{~m})$

30 in. $(76 \mathrm{~cm})$

18 in. $(45 \mathrm{~cm})$

39 in. $(99 \mathrm{~cm})$

7 psi

30 in. $(76 \mathrm{~cm})$

40 in. $(102 \mathrm{~cm})$

$3 \times 1$

4 in. $(10 \mathrm{~cm})$

4 in. $(10 \mathrm{~cm})$

.438 in. $(1 \mathrm{~cm})$

12 in. $(30 \mathrm{~cm})$ 
facility so appropriate remedial measures may be taken. Radiation levels in soil, sediment, vegetation, air, and surface and groundwater are measured on a periodic basis and compared with background levels established through the pre-operational monitoring program.

\section{B-3.7 Support Facilities}

The locations of various buildings and facilities that house support activities are shown in Figure B-6. These buildings include:

- Administration/Health

- Operations Support

- Maintenance/Equipment Storage

- Concrete Batch Plant

- $\quad$ Receiving and Storage.

Additional facilities include a water treatment plant, truck wash station, and buildings and areas set aside for storage of equipment and supplies.

\section{B-3.8 Facility Operations}

When a truck arrives at the disposal facility it is directed to the truck waiting area outside the main gate to await the sequencing of waste receipt, inspection, and disposal within the facility. When the disposal unit is ready to receive the waste, the truck is admitted through the main gate to a waiting area between the inner and outer fences. Shipping documents are examined to confirm the expected arrival of the shipment. To the extent possible, the shipping documents are checked with the actual packages of the shipment. A radiation survey is conducted to confirm that the shipment complies with U.S. Department of Transportation and U.S. Nuclear Regulatory Commission shipping regulations. Packages received on open trucks are surveyed and wiped unless they are contained in shielded shipping containers.

If the shipment is not accepted, the truck, with its load, is returned to the truck parking lot outside the main gate to await further action. If a damaged package is found that has released radioactivity, the package is sent to the Receiving and Storage Building for decontamination and repackaging. If, for some reason, a waste package is damaged and must be decontaminated and/or repackaged after it enters the disposal area, there is a truck bay on the inside of the fenced area of the Receiving and Storage Building for unloading that waste into the decontamination and repackaging area.

Shipments with waste packages contained in shielded shipping containers or in vans proceed to the receiving bay of the Receiving and Storage Building. For shielded packages, the shield lid is removed, the package is monitored and wiped to determine compliance with shipping regulations, and the lid is replaced for transport of the waste to the disposal unit. For vans containing packages of 
waste, the van is unloaded and each package of waste is inspected. Packages that have been unloaded from the van and accepted for disposal are placed on a flatbed truck for transport to the disposal unit.

Inclement weather or temporary unplanned cessation of disposal operations may require interim storage of the waste. This waste is placed in the temporary storage area of the Receiving and Storage Building. Separate areas are provided for waste that does not require shielding and for waste that does require shielding during storage.

At the Class $\mathrm{A}$ disposal unit, Class $\mathrm{A}$ wastes are unloaded using a gantry crane that straddles the vault. Three layers of waste packages each about $6 \mathrm{ft}$ thick can be held in each cell. Waste packages and pallets of waste are disposed of "as is" without removing the waste from the pallets. Packages are picked up and released using automatic systems to minimize manual involvement and radiation doses to workers. Class $\mathrm{A}$ wastes arriving in shielded transportation casks are placed in one of the two lower waste layers in the Class A disposal vaults. Void spaces between the waste packages are filled with dry, free flowing gravelly sand.

Class $\mathrm{B}$ and $\mathrm{C}$ wastes are off-loaded using a boom crane. Only two waste layers are placed in the Class $B / C$ disposal cells. All Class $B / C$ waste is removed from pallets that may have been used during transport. As with Class $A$ waste, packages of Class B and C waste are carefully placed to avoid damage and minimize void spaces. Void spaces are filled with sand. Shielding is used as necessary to protect workers during the placement of Class B and C waste. Three feet of earthen shielding material is placed between the two layers of Class $B / C$ waste, and $6 \mathrm{ft}$ of shielding and roof bedding is placed on top of the second layer of waste.

\section{B-4. WASTE CHARACTERIZATION}

The annual waste volume received at the site is assumed to be $235,000 \mathrm{ft}^{3}$. Approximately $95.6 \%$ of the volume $\left(224,600 \mathrm{ft}^{3}\right)$ and $15.7 \%$ of the activity $(4,000 \mathrm{Ci})$ is Class $\mathrm{A}$ waste. Approximately $4.4 \%$ of the volume $\left(10,400 \mathrm{ft}^{3}\right)$ and $84.3 \%$ of the activity $(21,500 \mathrm{Ci})$ is Class $\mathrm{B} / \mathrm{C}$ waste. Approximately two-thirds of the waste is from five pressurized water reactor (PWR) nuclear power plants and five boiling water reactor (BWR) nuclear power plants located in the region served by the disposal facility. There are approximately 200 industrial, academic institution, and medical institution waste generators that supply the remaining one-third of the LLW received at the facility. The annual waste volumes received, listed by waste source and general waste group, are shown in Table B-4.

The major radionuclides in the waste include four nuclides: $\mathrm{H}-3, \mathrm{Fe}-55$, Co-60, and Cs-137. 
Table B-4. Waste generators and annual disposal volume.

Waste source and type

Annual volume

Power Reactor

PWR - Dry

33,000

PWR - Wet

14,000

BWR - Dry

67,000

BWR - Wet

47,000

Total power reactor

161,000

Institutional

Trash

17,000

Process wastes

6,000

Total institutional 23,000

Industrial

Trash

38,000

Process waste

13,000

Total industrial

Total annual volume (all generators) 


\section{B-5. CHRONOLOGY}

A chronology of potential financial losses, showing the time period when the loss might occur, who or what might be adversely affected and how the loss is caused, is shown in Table B-5. In Table B-5, the 30-year operating life has been separated into two periods-the period from 0 to 5 years when operations at the facility are new or unfamiliar and accidents may be more likely to occur, and the period from 6 to 30 years when operational procedures are well-established and accidents are less likely. The five-year site closure period has also been separated into two periods-the period from 31 to 32 years during which actual closure and stabilization of the site takes place, and the period from 33 to 35 years during which the disposal facility operator is required to continue to monitor and maintain the site. The 100 -year post-closure period has been divided into three time periods -36 to 45 years, 46 to 60 years, and 61 to 135 years. As the post-closure period progresses, if no releases of radioactivity to the environment are detected, it is assumed that the level of surveillance and monitoring and the number of persons engaged in these activities will be reduced.

It should be noted that, following facility closure, the potential for offsite liability claims decreases significantly. This is primarily a result of the following factors:

1. The disposal structures containing the waste are closed in a manner that incorporates barriers specifically designed to protect against intrusion by both man and nature.

2. The disposal area is surrounded by a buffer zone that utilizes the natural characteristics of the area to contain the waste onsite.

3. The amount of radioactivity at the disposal facility constantly deceases over time in accordance with the natural law of radioactive decay. 
Table B-5. Chronology of potential financial losses.

\begin{tabular}{|c|c|c|c|}
\hline Time period & Phase & Who/what & How \\
\hline \multirow[t]{4}{*}{$0-5$} & $\begin{array}{l}\text { Startup and } \\
\text { operations }\end{array}$ & Workers (50) & $\begin{array}{l}\text { Startup accidents } \\
\text { Operational accidents }\end{array}$ \\
\hline & & Neighbors & $\begin{array}{l}\text { Releases (atmospheric, surface water) caused by } \\
\text { extreme natural occurrences }\end{array}$ \\
\hline & & Site damage & $\begin{array}{l}\text { Startup accidents } \\
\text { Extreme natural occurrences }\end{array}$ \\
\hline & & Trespasser & $\begin{array}{l}\text { Exposure to radiation } \\
\text { Carries contamination offsite }\end{array}$ \\
\hline \multirow[t]{4}{*}{$6-30$} & Operations & Workers (50) & $\begin{array}{l}\text { Operational accidents } \\
\text { Cancers }\end{array}$ \\
\hline & & Neighbors & $\begin{array}{l}\text { Releases (atmospheric, surface water) caused by vault } \\
\text { failure or extreme natural occurrences }\end{array}$ \\
\hline & & Site damage & Operational accidents or extreme natural occurrences \\
\hline & & Trespasser & $\begin{array}{l}\text { Exposure to radiation } \\
\text { Carries contamination offsite }\end{array}$ \\
\hline \multirow[t]{2}{*}{ 31-32 } & Closure & Workers (20) & $\begin{array}{l}\text { Industrial accidents } \\
\text { Cancers }\end{array}$ \\
\hline & & Neighbors & Releases due to vault failure \\
\hline \multirow[t]{2}{*}{ 33-35 } & Closure & Workers (15) & $\begin{array}{l}\text { Industrial accidents } \\
\text { Cancers }\end{array}$ \\
\hline & & Neighbors & Releases due to vault failure \\
\hline \multirow[t]{3}{*}{ 36-45 } & Maintenance & Workers (10) & $\begin{array}{l}\text { Industrial accidents } \\
\text { Cancers }\end{array}$ \\
\hline & & Neighbors & Releases due to vault failure \\
\hline & & Site damage & Vault failure \\
\hline \multirow[t]{3}{*}{$46-60$} & Maintenance & Workers (7) & $\begin{array}{l}\text { Industrial accidents } \\
\text { Cancers }\end{array}$ \\
\hline & & Neighbors & Releases due to vault failure \\
\hline & & Site damage & Vault failure \\
\hline \multirow[t]{3}{*}{$61-135$} & Maintenance & Workers (5) & $\begin{array}{l}\text { Industrial accidents } \\
\text { Cancers }\end{array}$ \\
\hline & & Neighbors & Releases due to vault failure \\
\hline & & Site damage & Vault failure \\
\hline
\end{tabular}




\section{B-6. REFERENCES}

1. U.S. Department of Energy, Prototype License Application: Safety Analysis Report, Belowground Vault," National Low-Level Waste Management Program, DOE/LLW-72T, October 1988. 


\section{Appendix C}

\section{Vault Failure Analysis}

C-1 


\section{Appendix C}

\section{Vault Failure Analysis}

The possibility of premature disposal vault failure was assessed using the BARRIER computer code. The BARRIER code $^{1}$ combines a standard structural analysis with concrete degradation mechanisms to predict the long-term performance of concrete structures used for waste disposal. The BARRIER code can also model variations or uncertainties in the input parameters and the effect of these variations on vault performance. The following paragraphs provide a brief description of the BARRIER code and the data and methodology used for the vault failure analysis.

The BARRIER code considers several degradation mechanisms for reinforced concrete. These include dissolution by sulfate attack, loss of strength by calcium hydroxide leaching, and corrosion of reinforcing steel. As these degradation processes occur, the concrete and reinforcing steel gradually lose their integrity and the structure ultimately fails. In this context, failure means that the structure loses its capacity to isolate waste from percolating water. Failure generally means that the structure has cracked to the extent that water may enter the disposal vault.

There are often uncertainties associated with the input parameters required to perform a BARRIER analysis. In order to address the effects of these uncertainties, the data may be entered into the BARRIER code as probability distributions. The data may be entered as uniform, normal, log-uniform, or log-normal probability distributions. The uniform and log-uniform distributions are specified by giving the range of variation of the parameter. The normal and log-normal distributions are specified by entering the mean value and the standard deviation or geometric standard deviation.

Once these distributions have been specified, the computer code performs a Monte Carlo analysis by calculating vault failure times for a number of statistical samples. Input data values for each sample are randomly selected from the input probability distributions. For the present analysis, 500 samples were evaluated and the cumulative probability of vault failure was evaluated as a function of time.

The mean values of parameters used to characterize the disposal units are taken from the Prototype License Application Belowground Vault report. ${ }^{2}$ Both Class A and Class B/C disposal units are included in this analysis. Table $\mathrm{C}-1$ shows the probability distributions for site-independent data. Uniform probability distributions were selected for all of these parameters. Table C-2 shows the distributions for site-dependent chemical concentrations used in the degradation analysis. Log-normal distributions were used for all of these parameters.

Failure times were calculated for 500 random statistical samples. Of these, failure was indicated in 303 of the Class A samples and 258 of the Class B/C samples. The cumulative failure probabilities for the first 500 years are shown in Table C-3.

The major concern associated with vault failure is the possibility of groundwater contamination. Following failure of a disposal vault, radionuclides might eventually migrate to groundwater. Individuals who use the contaminated groundwater could potentially receive a radiological dose that 
Table C-1. Distribution of site-independent parameters.

\section{Parameter}

Diffusion coefficients:

Calcium hydroxide

Oxygen

Sulfate

Weight percent of

$(\mathrm{CaO})_{3} \mathrm{Al}_{2} \mathrm{O}_{3}$ in cement

Initial compressive strength

of concrete

Modulus of subgrade reaction
Distribution

Range

Uniform

Uniform

Uniform

Uniform
4200 to 6200 psi

1.E-7 to $1 . \mathrm{E}-5 \mathrm{~cm}^{2} / \mathrm{s}$

1.E-7 to $1 . E-5 \mathrm{~cm}^{2} / \mathrm{s}$

3.E-8 to $3 . E-6 \mathrm{~cm}^{2} / \mathrm{s}$

1 to 7 percent

100 to $160 \mathrm{pci}$

Table C-2. Distribution of site-dependent parameters.

Geometric

Standard

Parameter

Distribution

Mean Value (mg/l)

Deviation

Chloride concentration:

Vault roof

Vault floor

Magnesium concentration:

Vault roof

Vault floor

Log normal

Log normal

Log normal

Log normal

4.8

4.8

2.5

2.5

Sulfate concentration:

Vault roof

Vault floor

Oxygen concentration
Log normal

Log normal

Log normal 
Table C-3. Cumulative vault failure probabilities.

\begin{tabular}{|c|c|c|c|}
\hline \multirow{2}{*}{$\begin{array}{l}\text { Time from } \\
\text { start (yr) }\end{array}$} & \multirow{2}{*}{$\begin{array}{l}\text { Time after } \\
\text { closure }(y r)\end{array}$} & \multicolumn{2}{|c|}{ Cumulative failure probability } \\
\hline & & Class A & Class B \\
\hline 50 & 20 & .000 & .000 \\
\hline 70 & 40 & .006 & .004 \\
\hline 90 & 60 & .014 & .010 \\
\hline 110 & 80 & .032 & .014 \\
\hline 130 & 100 & .074 & .032 \\
\hline 150 & 120 & .106 & .060 \\
\hline 170 & 140 & .152 & .086 \\
\hline 190 & 160 & .190 & .120 \\
\hline 210 & 180 & .218 & .150 \\
\hline 230 & 200 & .242 & .184 \\
\hline 250 & 220 & .268 & .214 \\
\hline 270 & 240 & .294 & .236 \\
\hline 290 & 260 & .332 & .246 \\
\hline 310 & 280 & .336 & .278 \\
\hline 320 & 300 & .398 & .298 \\
\hline 350 & 320 & .424 & .324 \\
\hline 370 & 340 & .458 & .358 \\
\hline 390 & 360 & .482 & .384 \\
\hline 410 & 380 & .502 & .402 \\
\hline 430 & 400 & .514 & .420 \\
\hline 450 & 420 & .530 & .438 \\
\hline 470 & 440 & .552 & .470 \\
\hline 490 & 460 & .576 & .484 \\
\hline 510 & 480 & .594 & .502 \\
\hline 130 & 500 & .606 & .516 \\
\hline
\end{tabular}

is dependent upon the level of contamination. The maximum individual groundwater dose depends on the time of failure of the vaults. For example, the longer waste is contained in the vault, the more radioactive decay will lessen the amount of radioactivity available for release. The maximum individual dose, as a function of vault failure time, is shown in Table C-4. If failure occurs after about 100 years, the doses from both the Class $A$ and the Class $B / C$ vaults are relatively constant because of the remaining long-lived radionuclides. 
Table C-4. Maximum projected doses for various disposal unit failure times.

\begin{tabular}{ccc}
\hline & \multicolumn{2}{c}{ Dose (mrem/yr) } \\
\cline { 2 - 3 } $\begin{array}{c}\text { Failure time } \\
\text { (yr) }\end{array}$ & Class A & Class BC \\
\hline 50 & 14.0 & \\
100 & 14.0 & 41.0 \\
150 & 14.0 & 7.5 \\
200 & 14.0 & 6.2 \\
400 & 13.0 & 6.1 \\
500 & 13.0 & 6.1 \\
& & 6.0 \\
\hline
\end{tabular}




\section{REFERENCES}

1. Shuman, R., V. C. Rogers, N. Chau, and G. B. Merrell, The BARRIER Code: A Tool for Estimating the Long-Term Performance of Low-Level Radioactive Waste Disposal Facilities, User's Manual, Version 1, Electric Power Research Institute, NP-6218-CCML, 1989.

2. U.S. Department of Energy, Prototype License Application: Safety Analysis Report, Belowground Vault, National Low-Level Waste Management Program, DOE/LLW-72T, October 1988. 
Appendix D

Glossary

D-1 


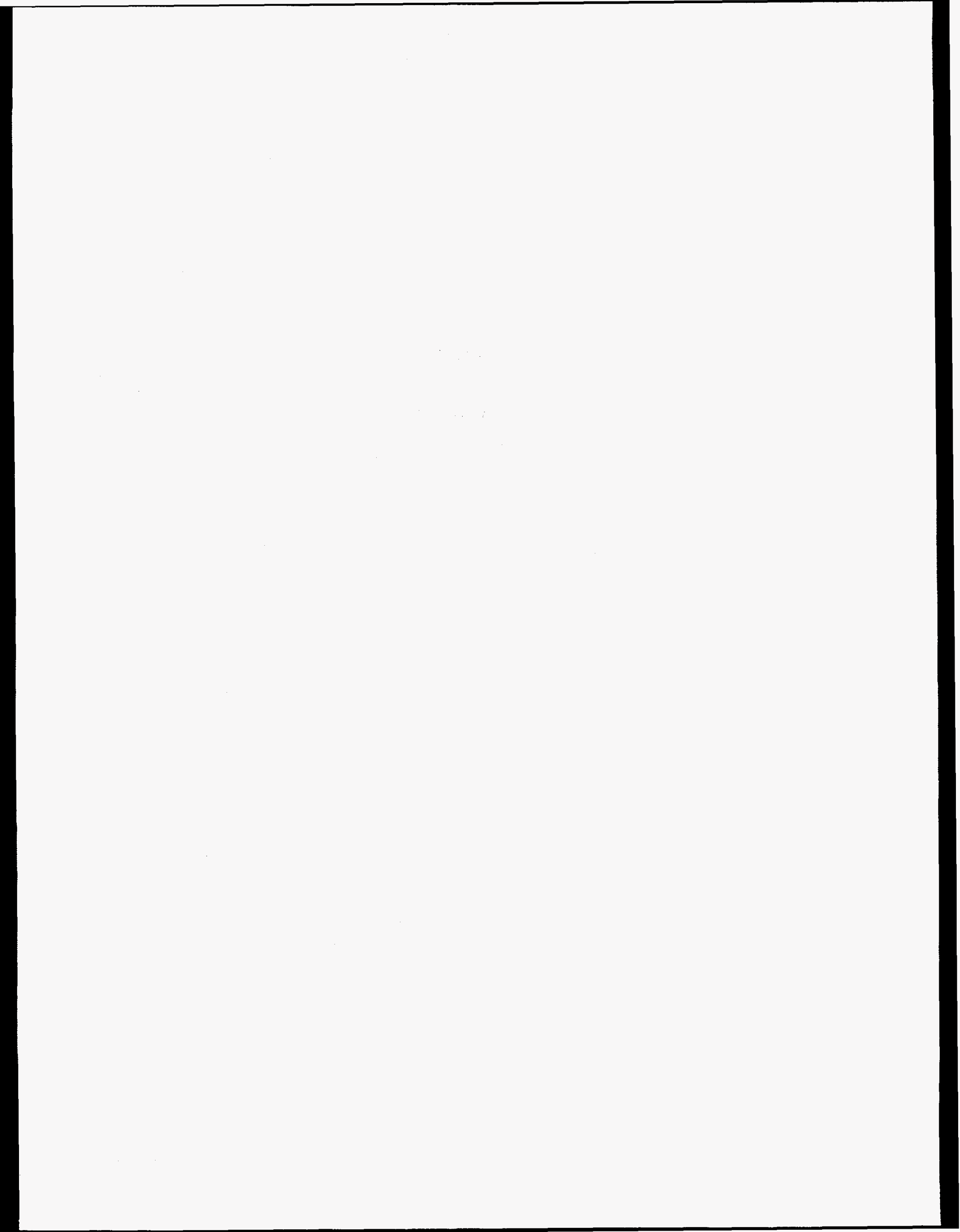




\section{Appendix D}

\section{Glossary}

10 CFR 61: Federal regulations regarding low-level radioactive waste disposal found in the Code of Federal Regulations (CFR) at 10 CFR Part 61.

AEA: Atomic Energy Act; the original federal legislation that established regulatory control (Atomic Energy Commission, now the Nuclear Regulatory Commission) over the nuclear industry.

AIG: American International Group; is one of the largest insurance groups in the World. It is noted for its willingness to write many types of risk that others are not willing to, for example, pollution (EIL) insurance.

ANI: American Nuclear Insurers; An insurance pool that writes the risks of the nuclear energy industry. The pool members are all insurance companies who have combined their resources for the specialized nature of the nuclear risk.

Burning Layer: Potential losses that are considered relatively frequent or probable, relatively moderate in cost, and relatively predictable.

Captive Insurance Company: A type of self-insurance whereby an insurance company is established by an owner or owners to insure the risks of that owner or owners.

CERCLA: Comprehensive Emergency Response Compensation and Liability Act; provides the EPA authority to clean up contaminated sites. CERCLA addresses past activities that must be rectified now.

CGL Policy: Comprehensive General Liability; the standard insurance policy to protect an insured institution against offsite liability (injury or property damage to others).

Claims-made Insurance: An insurance policy that covers only those losses that are claimed during the policy period.

Discovery Period: An extension period on a claims-made policy. Because it takes time for losses to be "discovered" and reported, when a claims-made policy is ended, an extension is granted to claim losses to the contract (but only for losses that occurred during the contract).

DOE: U.S. Department of Energy.

DOT: U.S. Department of Transportation.

EIL Insurance: Environmental Impairment Liability Insurance; a specific insurance policy to protect an insured for liabilities to third parties arising from pollution caused by the insured.

EPA: U.S. Environmental Protection Agency. 
Excess Layer: All potential losses in excess of the burning layer that are less predictable because of infrequency or low probability and more significant financially because of size.

Financial Assurance Mechanism: In the NRC's guidelines, any legally binding plan to cover future costs for closure and post closure.

Financial Guarantee: Any method whereby a party pledges assets that could be used later to pay for a predefined situation, such as a loss or lack of performance. Examples include bank letters-ofcredit, escrow fund, and special earmarked funds. A surety bond is a more formal type of financial guaranty backed by the assets of an independent party.

Going Bare: Noninsurance as opposed to self-insurance, a formal decision to retain risk and finance that risk in some manner.

Insurance: Insurance is a financial arrangement where one party, recognized and licensed to do so by the states, agrees to compensate another for a loss if it results from the occurrence of a specified activity. Insurance may be defined as a device for reducing risk by combining a sufficient number of exposure units to make their collective individual losses statistically predictable. The cost of predictable losses is then shared proportionately by all units in the combination by preparing a statistical premium.

Insured: Party purchasing the insurance contract.

Insurer: Party offering the insurance contract.

LLRWPA: Low-Level Radioactive Waste Policy Act (1980); established the federal policy for LLW, that made each state responsible for all commercial LLW generated with the state and encouraged states to provide disposal capacity on a regional basis through joint state "compact regions."

LLRWPAA: Low-Level Radioactive Waste Policy Act Amendments (1985); established a timetable for state compliance with the original act with penalties for noncompliance.

Long-tail: Refers to the long time span between the occurrence of a loss-producing activity and when the loss becomes manifest.

NRC: U.S. Nuclear Regulatory Commission.

Occurrence Insurance: An insurance policy that covers any losses occurring during the term of the policy regardless of when it is reported. An occurrence policy is considered broader because many liability situations take many years to become manifest, for example, health effects, product defects, or pollution.

Present Value: The monetary value today of an amount to be paid or due in the future. Present value is calculated using a standard financial equation that reflects the amount a dollar is projected to lose each year. 
Probable Loss: Value of a potential loss recognizing both the potential magnitude of loss and the probability of loss. (Magnitude of loss $\times$ probability of loss $=$ expected loss.)

RCRA: Resource Conservation and Recovery Act; provides the EPA authority to enforce standards for hazardous waste generation and disposal. RCRA covers on-going activities.

Reinsurance: Method of transferring some or all of the potential insurance liabilities assumed by one insurance entity to another.

Risk Retention Group: A special form of captive insurance company that is established under special federal legislation (as opposed to most insurance that is controlled by the state) and is restricted to insuring liability risks only. The group insures only the risks of its owners.

Security Bond: A special insurance mechanism in which the insurer pays a third party for losses due to lack of performance, but is allowed to recoup this loss from the insured. A surety is written and priced anticipating that no loss will occur when an independent guaranty is necessary.

Sclf-Insurance: A formal decision to retain risk rather than purchase insurance. A self-insurance program is distinguished from noninsurance or risk retention through deductibles by the need for a financing program; that is, systems and procedures for the payment of losses as they occur. Selfinsurance is not simply the absence of insurance; it is a planned, methodical approach to the assumption of risk, including the setting aside of resources to pay losses when they occur.

Superfund: Common term for the CERCLA regulations. Also denotes a site that the EPA has targeted for clean up under CERCLA and the trust fund established to pay for cleanup of Superfund sites.

Voluntary Pool: Can refer either to a group of entities joining together to protect each other from financial losses (could be informal agreements or specialized captive companies) or to a group of insureds coming together to offer a type of insurance coverage (e.g., ANI is the pool of large insurance companies that offer the high limits and special services needed by the nuclear industry). 
Appendix E

Bibliography

E-1 


\section{Appendix $E$}

\section{Bibliography}

Adler, Stacy, "EPA Tank Rules Spawn Separate EIL Market," Business Insurance, November 20, 1989 , p. 3.

This report, with related side-bar articles, provides a broad overview of insurance market conditions for 1990 in the environmental field. Emphasis included recent changes in underground storage tank regulations and market responses.

American Nuclear Insurers. Betterley Risk Consultants conducted a telephone interview with the Underwriting Department of American Nuclear Insurers on Monday, July 23, 1990, to get the most up-to-date information on nuclear coverages in general and availability since the moratorium.

Ashford, Nicholas, S. Moran, and R. F. Stone, The Role of Insurance and Financial Responsibility Requirements in Preventing and Compensating Damage from Environmental Risks, Center for Technology, Policy and Industrial Development, Massachusetts Institute for Technology, Final report, January 1989.

In a report to the New Jersey Department of Insurance, this group takes a risk management approach to discuss ways to reduce and control exposures to toxic substances through the use of regulations and financial assurance requirements. These requirements protect the public by preventing losses; under-financed or irresponsible operators are prevented from entering the market.

Brown, Omer F., "Low-Level Radioactive Waste Liability Considerations," identical speeches delivered at Low Level Nuclear Waste Cleanup Conference, April 17, 1984, and Waste Management '84 Symposium, March 14, 1984.

This paper gives a regulatory and legal background to the principles of liability that arise from the operation and postclosure/institutional care of a LLW site. It then turns to the topic of available insurance mechanisms and how states may need to fund for liabilities not covered by insurance.

Cole, Mitchell J. and M. Levin, "The Evolution of Private Insurance: Setting the Stage for the Risk Retention Act," The Risk Retention Act: Bane or Blessing? Society of CPCU, 1989, pp. 1-4.

This article, contained in a special report published by the insurance industry's Society of CPCU, covers the growth in alternatives to traditional insurance, such as self-funding, risk retention groups, and captive insurance companies (company-specific or group-specific). Legal issues and advantages/disadvantages of each are covered. 
Debaets, Marc, "Nuclear Insurance in the Nineties." Viewpoint, Marsh \& McLennan Companies, Winter 1990, pp. 23-26.

In question-and-answer format, the author discusses recent issues relating to nuclear insurance availability and compares the U.S. situation to that in Europe and Japan.

Diacogiannis, John N., "Low Level Radioactive Waste Liability," Speech to U.S. Council for Energy Awareness Nuclear Insurance Conference, January 25, 1989.

Mr. Diacogiannis is senior insurance analyst for Pennsylvania Power \& Light. Topics covered in this report include the problem of perceived risk and how it affects thinking about potential liability for a LLW site. A discussion of Pennsylvania's plan of action for LLW follows. Finally, the moratorium by American Nuclear Insurers and Pennsylvania's regulatory effort to clarify potential liability at a LLW site is addressed.

Egan, James T., Regulatory Management; $A$ Guide to Conducting Environmental Affairs and Minimizing Liability, Lewis Publishers, Chelsea, Michigan, 1991.

Guidebook on steps to take in managing environmental affairs. Describes resource needs, offers techniques, shares approach philosophies, and seeks to initiate the commitment and processes that will produce answers to specific situations. The book provides a structure with which to respond to and manage environmental/regulatory issues and impacts.

"Environmental Risk Evaluation," Claims Magazine, January 1990, pp. 50-51.

This article discusses a CPCU seminar about environmental insurance. While the courts have generally been unfavorable (i.e., forcing insurers to pay for excluded environmental damages), by applying risk evaluation and proper engineering techniques, pollution liability can be underwritten for new sites.

"EPIC Stops Underwriting," Business Insurance, January 15, 1990, pp. 2.

One pollution liability underwriter, EPIC, withdrew from the marketplace because of lack of interest. Underlying reasons for the withdrawal are shown.

The Fire, Casualty and Surety Bulletin (FC\&S), Cincinnati, OH, National Underwriter Co., continually updated.

These volumes are key resources in gathering the latest information on coverage, markets, and availability of different types of coverage. An analysis of Nuclear Insurance is contained in Volume 4, updated July 1989. A thorough analysis is given of the ANI facilities form policy, its coverages, limitations, definitions, and exclusions.

Guerrero, Peter F., "Potential Liability of Property/Casualty Insurers for Costs of Cleaning Up Hazardous Waste Sites," U.S. General Accounting Office, GAO/T-RCED-90-109, September 27, 1990. 
Statement issued by Mr Guerrero, Associate Director, Environmental Protection Issues; Resources, Community, and Economic Development Division before the Subcommittee of Policy Research and Insurance, Committee of Banking, Finance, and Urban Affairs, U.S. House of Representatives.

Hagedorn, Ann and W. Green, "Compensating Victims of Nuclear Disaster," The Wall Street Journal, June 8, 1990.

This article discusses a draft report being prepared for President Bush on possible mechanisms to expedite claims should a nuclear catastrophe ever occur. Consolidated adjudication with predetermined scales of liability is recommended.

Hamilton, Thomas M. and E. Routman, "Cleaning up America: Superfund and Its Impact on the Insurance Industry," The Society of CPCU Journal, pp. 172-184.

This article is a survey and overview of significant case law addressing coverage issues relating to toxic tort liability. Background information on the CERCLA and RCRA regulations is given. The focus is how insurance liability policies have been called upon to respond to environmental damages.

Jablon, Seymour, et al., "Cancer in Populations Living Near Nuclear Facilities," National Cancer Institute, Division of Cancer Etiology, Epidemiology and Biostatistics Program, NIH Publication No. 90-874, July 1990 .

Report of a survey of persons residing near all 62 federal and private nuclear facilities that were in service prior to 1982. No evidence was found to suggest that the occurrence of leukemia or any other form of cancer was generally higher in the study counties (in and adjacent to which nuclear facilities were located) than in the control counties.

Kansas Insurance Department (as author), "Liability Insurance for Low-Level Radiation Waste Compact Facility," memo to the Central Interstate Low-Level Radioactive Waste Commission, June 4, 1987.

Kansas, as the alternate home state for a regional compact, addresses the issue of the obligations imposed on the compact from the LLW disposal facility. The key topic covered is nuclear insurance coverage for liability/protection of the general public. Other insurance topics are addressed.

Labaton, Stephen, "Six U.S. Judges Will Meet on Burden of Asbestos Suits," The New York Times, July 21,1990, p. 31.

Because of the extremely complicated system in adjudicating asbestos claims, six judges are gathering in an almost unprecedented action to streamline court actions and ensure equity to claimants.

Last, Michael P., "Tort Law Implications of Hazardous Waste Facilities," Natural Resources Lawyer, Natural Resources Law Section, American Bar Association, 1984, pp. 491-507. 
This article outlines the bases by which an injured party might seek recovery against a LLW site for bodily injury or property damage. Remedies covered originate in common-law (negligence, strict liability); this article is not about regulatory/statutory remedies. A discussion of defenses available in common-law is included.

Liner, John, "The Liability Risk Retention Act of 1986: New Federal Law Fuels Captive Movement," The John Liner Newsletter, May 1987.

A comprehensive review of the formation and regulation of a risk retention group. The intent of the risk retention act was to create a legal environment conducive to the formation of alternative facilities for self-insuring liability risks because of an extremely limited standard insurance market.

The Low-Level Radioactive Waste Forum, Meeting Reports from sessions April 30, 1987; October 5-7, 1987; April 19-20, 1988; January 11-13, 1989.

The LLW Forum, an interest group of state or state-compact representatives, has addressed the issue of financial assurance at a number of meetings. These reports summarize the presentations and discussions at the meetings.

a. April 30, 1987: A review of available alternative financing mechanisms, including a discussion of the applicability of Price-Anderson Act; long-term care funding; captive insurance companies, or risk retention groups.

b. October 5-7, 1987: Overview of insurance for nuclear and environmental risk; a discussion of potential liabilities for onsite remediation and offsite damages.

c. April 19-20, 1988: A look at three states' progress in addressing LLW financial assurance requirements included discussion of different mechanisms available and the different liability potentials for a site.

d. January 11-13, 1989: A discussion of the state of environmental impairment liability insurance, and different ways to address the onsite and offsite potential liabilities.

Marcus, Amy and C. Harlan, "Pollution Exclusion Losses in Wisconsin" The Wall Street Journal.

In a recent decision, the Wisconsin Supreme Court found the so-called Pollution Exclusion found in standard insurance liability contracts to be "ambiguous" and thus interpreted in favor of an insured seeking coverage for environmental damage.

Mayo, Louis M., et al., Liability for Low Level Radioactive Wastes, Program of Policy Studies in Science and Technology, George Washington University, May 1982.

A thorough overview of the legal liability aspect of LLW management is included in this 70-page specialized report. Topics covered include the federal statutory system, state tort theory, the Price-Anderson Act, and liability arising from the various life-cycle phases of a LLW site. 
McGhee, Neil, "U.S. Insurers Missing Out on Nuclear Market," National Underwriter (Property/Casualty), April 16, 1990, p. 4.

This article points out that U.S. insurers are missing out on a potentially highly profitable market because of fears of any liability related to the environment. Foreign sources are providing major amounts of capacity to the U.S.

McGrath, Kathleen, "Personal Injury Claims Now Arising Out of Environmental Liability Suits," Insurance Times, December 5, 1989, p. 11.

Insureds have taken a novel approach in seeking recoveries from their insurance policies. This report shows how insureds are submitting-and insurers defending-claims that pollution constitutes an act of personal injury (e.g., invasion of privacy) and thus covered by standard insurance liability policies.

McGregor, Gregor I., "Insurance Woes: How to Collect on Hazwaste Claims," Environmental Protection, Jan/Feb, 1991.

Descriptions of insurance coverages relevant to hazardous waste management with suggestions for dealing with insurance companies for damages arising out of releases of hazardous waste.

Mehr, Robert I., Fundamentals of Insurance, Homewood, IL, Richard D. Irwin, Inc., 1983.

This is a basic text on insurance principles and practices.

Merz, Jon F., "Low Level Waste Injury: Liability, Insurance, and Indemnification," Insurance Counsel Journal, July 1986, pp. 362-380.

This report is a comprehensive review of the regulatory and common law roots of liability in managing LLW waste. The author then focuses on potential and available sources of funds to address these liabilities, for example, Price-Anderson extension, insurance, and a dedicated fund. The author suggests a system of "liquidated damages" to most efficiently serve claimants in case of radioactive exposure.

We also reference in our report, notes taken of a Jon F. Merz speech in 1987, site or forum not indicated, which summarized or expanded on the topics addressed at length in the article. This was titled, "Low Level Waste Insurance Discussion," and noted as such when utilized in our text.

Murphy, James F., "Hazardous Waste Litigation Explodes: A Pandora's Box of Issues," Claims Magazine, January 1990, pp. 34-37, 63-67.

This article is a thorough analysis and compendium of case law relating to pollution liability and the standard insurance liability contract (CGL). Apparently intended to exclude coverage for gradual pollution, the CGL has been subject to a diversity of decisions regarding when an insurance company must defend and when an insurance company must pay for pollution-related claims. Expansion of coverage by aggregating many policies over many years is a major problem. 
New York State Department of Environmental Conservation, Final Generic Environmental Impact Statement for Promulgation of 6 NYCRR, Subpart 383-6, Financial Assurance Requirements for Low-Level Radioactive Waste Disposal Facilities, Division of Hazardous Substances Regulation, Bureau of Radiation, September 1991.

A comprehensive evaluation of numerous issues related to regulating the provision of financial assurances for LLW disposal facilities. Includes an evaluation of New York laws and regulations, description of a risk assessment methodology, identification of activities that might cause financial losses, and an estimate of the financial consequences of various activities.

New York State Department of Environmental Conservation, Risk Assessment and Financial Surety Requirements for Transportation of Low-Level Radioactive Waste in New York State, Generic Environmental Impact Statement for Promulgation of 6 NYCRR, Subpart 381, Regulations for Low-Level Radioactive Waste Transporter Permit and Manifest System, Division of Hazardous Substances Regulation, Bureau of Radiation, February 1988.

A comprehensive evaluation of numerous issues related to regulating the transportation of LLW. Includes a description of a risk assessment methodology, identification of activities that might cause financial losses, and an estimate of the financial consequences of various activities.

Northeast Interstate Low Level Radioactive Waste Commission, Financial Assurance Workshop Report, July 19, 1989.

The material developed at this workshop was vital to our study in its timeliness and broadness of approach. Representatives included: CT and NJ officials (those two states form the NE Compact) and compact officials, a Nuclear Regulatory Commission LLW official, a site contractor/operator, and members of the nuclear insurance industry. Topics of discussion included the regulatory environment, insurance products available (or reasons that products are unavailable), and discussions of alternative means of financing potential liabilities.

Neis, Tracy, "Cleaning Up the Environmental Insurance Mess," Best's Insurance Management Reports, June 1990.

This article discusses the financial assurance requirements placed on environmental remediation contractors by the EPA. Because of a lack of insurance in the traditional market, contractors must look to alternative means of complying with the requirements, for example, captive insurance companies, or as one contributor suggested, a government-sponsored indemnification program.

Oliveira, Robert A., "Nuclear Liability Insurance Interest in Radioactive Waste Management at Utility Power Reactors," American Nuclear Insurers, 1985.

In this paper, the author describes the functioning of the American Nuclear Insurers insurance policy and how it relates to the Price-Anderson mechanism. The focus of the paper is on claims and claims avoidance (loss control). While it was originally felt that the greatest potential liability exposure would be a catastrophic power plant accident, history and claims analysis shows 
that small releases of radiation, even within regulatory guidelines, have caused a great number of third-party claims and employee claims for damages.

Petterson, John S., "From Perception to Reality: The Goiania Socioeconomic Impact Model," Waste Management '88: Symposium on Waste Management, February 28, 1988.

This paper is the text of a speech given at the symposium regarding the social, economic, and political impact of radiation exposure to a small group of citizens of Goiania, Brazil. Even though the accident was small when compared on an objective scale to other industrial accidents, the impact was driven by heightened fear and perceived risk relating to radiation.

Practical Risk Management, Oakland, CA, Practical Risk Management, Inc., continually updated.

This two-volume set is a standard reference both for risk financing topics (e.g., insurance and self-insurance mechanism), plus a topic-by-topic guide to a wide range of property and casualty lines of business. The chapter of nuclear risks, in Volume 2 at Chapter G13, describes coverages available under conventional and nuclear policies. This is an excellent source of background material.

Quattrocchi, John L., "Liability Insurance for Low Level Radioactive Waste Disposal: An Underwriter's Perspective." Speech delivered at United States Council for Energy Awareness Conference on Nuclear Insurance, January 22-25, 1989.

The author, American Nuclear Insurers Vice President for Underwriting, discusses the reasons for the moratorium on writing new radioactive waste disposal sites by ANI. The general expansion of liability in an unfavorable legal environment for pollution claims in general, and ANI's ongoing dispute over cleanup costs at Maxey Flats were given as reasons for ANI's reluctance. The author stressed that they would return to the LLW field, which has subsequently happened in 1990.

Richmond, C., Financial Responsibility Issues Related to Low-Level Waste Management, Transportation, and Disposal in Washington State, Washington Department of Ecology.

The State of Washington is the site of one of only three currently operating LLW disposal sites, and will continue to accept waste in the future under the terms of the federal LLW legislation of 1980. With a lack of cost data/historical experience, there is great difficulty in assessing what the risks of damages to others and on-site cleanup in case of an accident are. This paper explores some of the issues related to the difficulty.

Risk Financing: A Guide to Insurance Cash Flow, Dallas, TX, International Risk Management, Inc., 1988.

This is a two-volume comprehensive reference book on insurance, insurance plans, and alternative risk financing mechanisms. Topics on self-insurance types gave solid background information on areas like risk retention groups, funding plans, captives, etc. 
Superfund Report, August 17, 1988.

This newsletter covers developments in the cleanup of "Superfund" sites. In this issue, it was reported that the EPA had reached a "de minimis" settlement with certain generators of waste disposed at a New Jersey superfund site. It was the first time the EPA had allowed small contributors of waste to reach a settlement without being held potentially totally responsible for cleaning up a polluted site under the "joint and several" liability theory.

Tarnoff, Stephen, "Westinghouse Starts Huge Coverage Battle," Business Insurance, June 16, 1987, p. 1.

Westinghouse, facing huge costs for pollution at various manufacturing and storage sites, has decided to seek coverage from all its liability and property insurers of the prior $\mathbf{3 0}$ years. This article pointed out the confusion and difficulty in this insurance industry regarding pollution.

Thomas, K T. and D. J. Squires, "Public Understanding of Radioactive Waste Management Issues: Perspectives and IAEA's Role," IAEA Bulletin, April 1989.

Presents a summary of major industrial disasters and compares health effects and damages that resulted. Describes activities by IAEA to assist in educating and informing the public about the risks of radioactive waste management.

Task Force on Liability Insurance Report, The National Governors Association, August 1986.

This report details the "crisis" which occurred in the mid-80's for government and business in finding liability coverage in the traditional insurance market place. The extent of, reasons for, and possible solutions to the unavailability problem were covered. Environmental insurance issues were addressed.

Tydings, Joseph D. and C. Sponseller, "Insurance Company Required to Pay Landfill Cleanup Costs," Public Risk Magazine, March/April 1990, pp. 21-22.

The unfavorable court rulings (for insurers) in the area of environmental claims/pollution continues. This article covered a recent decision that made CNA, an insurer, liable for defense costs and cleanup costs incurred by New Castel, Delaware when the county waste disposal site was placed on the EPA's Superfund cleanup list.

U.S. Congress, Office of Technology Assessment, Complex Cleanup; The Environmental Legacy of Nuclear Weapons Production, OTA-O-484, February 1991.

A review of environmental problems associated with U.S. Department of Energy's production of nuclear weapons and recommendations for improvements in DOE's remediation efforts. Identifies experience with cleanup costs.

U.S. Department of Energy, Prototype License Applications: Safety Analysis Report, Belowground Vault, Nuclear Energy Low-Level Waste Management Program, DOE/LLW-72T, October 1988. 
Safety analysis report prepared by under DOE's auspices to clarify regulatory needs and intents in the licensing of low-level radioactive waste disposal facilities under 10 CFR 61.

U.S. Department of the Interior, "43 CFR Part 11, Natural Resource Damage Assessments," Federal Register, Vol. 51, No. 148, pp 27674, et seq., August 1, 1986.

Establishes procedures for assessing damage to natural resources under either the Comprehensive Environmental Response, Compensation, and Liability Act or the Clean Water Act.

U.S. Department of the Interior, "43 CFR Part 11, Natural Resource Damage Assessments," Federal Register, Vol. 56, No. 82, pp 13752, et seq., April 29, 1991.

Proposes revision to 43 CFR 11 procedures for assessing damage to natural resources under either the Comprehensive Environmental Response, Compensation, and Liability Act or the Clean Water Act.

U.S. General Accounting Office, Insurer Failures: Property/ Casualty Insurer Insolvencies and State Guaranty Funds, General Government Division, GAO/GGD-87-100, July 1987.

Report to Congress describing problems in the liability insurance community caused by failures of property/casualty insurers.

U.S. General Accounting Office, Hazardous Waste: Funding of Postclosure Liabilities Remains Uncertain, Resources, Community, and Economic Development Division, GAO/RCED-90-64, June 1990.

Review of postclosure liabilities and the means available to assure the financial needs of TSD facilities will be met. Extent of postclosure liabilities is unknown and cannot be quantified. Few options exist to provide necessary assurance.

U.S. General Accounting Office, Hazardous Waste: Pollution Claims Experience of Property/Casualty Insurers, Resources, Community, and Economic Development Division, GAO/RCED-91-59, February 1991.

Report to the Chairman, Subcommittee on Policy Research and Insurance, Committee of Banking, Finance, and Urban Affairs, U.S. House of Representatives.

U.S. Nuclear Regulatory Commission, "Standards for Protection Against Radiation," Federal Register, Vol. 25, pp 10914 et seq., November 17, 1960.

Identifies regulations that apply to licensees who are authorized to handle radioactive materials, including waste. Addresses worker protection as well as protection for members of the general public.

U.S. Nuclear Regulatory Commission, "Licensing Requirements for Land Disposal of Radioactive Waste," Federal Register, Vol. 47, pp 57463 et seq., December 27, 1982. 
Identifies regulations that apply to the development, operation. closure, and long-term maintenance of low-level radioactive waste disposal facilities.

U.S. Nuclear Regulatory Commission, Standard Review Plan for the Review of a License Application for a Low-Level Radioactive Waste Disposal Facility; Safety Analysis Report, Office of Nuclear Material Safety and Safeguards, NUREG-1200, Rev. 1, January 1988.

Detailed descriptions of the information sought in a LLW disposal facility license application, the evaluations NRC staff will perform, and the criteria they will use to judge the acceptability of such license applications.

U.S. Nuclear Regulatory Commission, Standard Format and Content of a Low-Level Radioactive Waste Disposal Facility; Safety Analysis Report, Office of Nuclear Material Safety and Safeguards, NUREG-1199, Rev. 1, January 1988.

General descriptions of the information sought in a LLW disposal facility license application.

Washington State Department of Ecology, Low Level Radioactive Waste Program, Liability Insurance Study: A Report to the 50th Legislature, December 1986, and Financial Responsibility for Liability and Cleanup for Radioactive Materials Licensees and Low Level Radioactive Waste Permittees: A Report to the 50th Legislature, December 1987.

These reports-an interim overview in 1986 and final report in 1987 -review the scope of potential liabilities that may be incurred by generators, shippers, and disposal site operators of LLW, and the adequacy and availability of insurance products in the environmental and nuclear areas to cover the liabilities. The final report concluded that there were limited insurance options available and special funding mechanisms should be developed, particularly in the area of cleanup costs. 